\title{
Synopsis of Lasioglossum (Dialictus) Robertson, 1902 (Hymenoptera, Apoidea, Halictidae) in Japan, the Korean Peninsula and Taiwan
}

\author{
Ryuki MURAO ${ }^{1, *}$, Osamu TADAUCHI ${ }^{2}$ \& Heung-Sik LEE ${ }^{3}$ \\ ${ }^{1,2}$ Department of Biological Science, Faculty of Sciences, Kyushu University, \\ Fukuoka, 812-8581 Japan. \\ ${ }^{3}$ Animal and Plant Quarantine Agency, Suwon, Korea. \\ "Corresponding author: r.murao@mbr.nifty.com, murao.ryuki.969@m.kyushu-u.ac.jp \\ ${ }^{1}$ urn:lsid:zoobank.org:author:7E665839-6675-4365-A7EA-169D4E4DA008 \\ ${ }^{2}$ urn:lsid:zoobank.org:author:1A22CC5E-A7A0-449E-994D-D939EEF5BF42 \\ ${ }^{3}$ urn:1sid:zoobank.org:author:BEA91CE0-9306-4AC4-8E90-5FD07A69B7AE
}

\begin{abstract}
Twelve species in total are recognized for the subgenus Lasioglossum (Dialictus) Robertson, 1902 from Japan, the Korean Peninsula and Taiwan. Lasioglossum (Dialictus) alishanense sp. nov. and $L$. (D.) taiwanense sp. nov. from Taiwan, are described as new. Four species are recorded from the following localities for the first time: L. (D.) miyabei Murao, Ebmer \& Tadauchi, 2006 from the Korean Peninsula (South Korea); L. (D.) ellipticeps (Blüthgen, 1923), L. (D.) virideglaucum Ebmer \& Sakagami, 1994 and L. (D.) viridellum (Cockerell, 1931) from South Korea. Lasioglossum (Dialictus) atroglaucum (Strand, 1913) is redescribed, L. (D.) ellipticeps, L. (D.) problematicum (Blüthgen, 1923), L. (D.) virideglaucum, and $L$. (D.) viridellum are supplementary described. A key to species is provided. Bionomical data, such as flight and flower records or habitat, are reported for some species. The distributions of all species are mapped. DNA barcodes of $L$. (D.) miyabei, L. (D.) pseudannulipes (Blüthgen, 1925), and L. (D.) virideglaucum are provided.
\end{abstract}

Key words. Halictidae, Lasioglossum, Dialictus, Far East Asia.

Murao R., Tadauchi O. \& Lee H.-S. 2015. Synopsis of Lasioglossum (Dialictus) Robertson, 1902 (Hymenoptera, Apoidea, Halictidae) in Japan, the Korean Peninsula and Taiwan. European Journal of Taxonomy 137: 1-50. http:// dx.doi.org/10.5852.ejt.137

\section{Introduction}

The cosmopolitan bee genus Lasioglossum Curtis, 1833 (Halictidae, Halictinae) is a highly diverse group and includes approximately 1800 species worldwide (Ascher \& Pickering 2015). This group contains diverse social structures (solitary, parasocial, and primitively eusocial, etc., reviewed in, e.g., Michener 1974; Yanega 1997), and are some of the most abundant bees in the warm temperate zone and parts of the Neotropical Region (Sakagami et al. 1967; Sakagami \& Fukuda 1973; Yamauchi et al. 1974; Ikudome 1992; Maeta et al. 2003; Gôukon 2006; etc.). It is divided into two informal group on the basis of the degree of strength of the second submarginal vein of the female fore wing (Michener 2000):

1) the Hemihalictus series (weak-veined Lasioglossum) includes all subgenera with a weak second submarginal vein (Acanthalictus Cockerell, 1924, Austrevylaeus Michener, 1965, Capalictus Pauly, 
Gibbs \& Kuhlmann, 2012, Dialictus Robertson, 1902, Dialictus sensu lato, Eickwortia McGinley, 1999, Evylaeus Robertson, 1902, Evylaeus sensu lato, Hemihalictus Cockerell, 1897, Paradialictus Pauly, 1984b and Sphecodogastra Ashmead, 1899).

2) the Lasioglossum series (strong-veined Lasioglossum) includes all subgenera (Australictus Michener, 1965, Callalictus Michener, 1965, Chilalictus Michener, 1965, Ctenonomia Cameron, 1903, Glossalictus Michener, 1965, Homalictus Cockerell, 1919, Ipomalictus Pauly, 1999, Lasioglossum, Leuchalictus Warncke, 1975, Papualictus Michener, 1980, Parachilalictus Pauly et al., 2013, Parasphecodes Smith, 1853, Pseudochilalictus Michener, 1965, Quasilictus Walker, 1986, Rubrihalictus Pauly, 1999 and Urohalictus Michener, 1980) with a strong second submarginal vein (modified from Michener (2007), including the subgenera proposed or re-established in recent phylogenetic and taxonomic studies (Gibbs et al. 2012, 2013; Pauly et al. 2012, 2013)).

Each series is monophyletic as supported by phylogenetic analyses based on molecular data (Danforth et al. 2003; Gibbs et al. 2012). However, there is no agreement among taxonomists with regard to the number and extent of the subgeneric classification of Lasioglossum and it is not necessarily applied when classifying the male. The Palaearctic subgenera Acanthalictus, Evylaeus, Dialictus, Hemihalictus and Sphecodogastra of the Hemihalictus series, e.g., have been treated as L. (Evylaeus) (e.g., Ebmer 2002; Murao \& Tadauchi 2007; Pesenko 2007a, as the genus Evylaeus). Recent phylogenetic studies (Danforth 1999; Danforth et al. 2003; Gibbs et al. 2012, 2013) based on molecular data, however, do not recognize L. (Evylaeus), used by most Palaearctic researchers, as a monophyletic group. They will probably shed light on our understanding of the relationships among taxa, evolutionary patterns of sociality and the strict delimitation of genera and subgenera.

In eastern Asia, taxonomic studies of the Lasioglossum group, with 217 species (Murao 2015), have been provided from the following areas: East Palaearctic Region (Pesenko 2006); Mongolia (Ebmer 1982, 2005); Russian Far East (Ebmer 1996, 2006; Pesenko 2007b); China (Ebmer 1998, 2002); Japan (e.g., Murao \& Tadauchi 2007; Murao et al. 2009b); Korean Peninsula (Ebmer 1978; Murao et al. 2014). However, the basic information on the Lasioglossum fauna in eastern Asia is still poor, particularly in the Oriental Region.

Dialictus Robertson, 1902 is one of the subgenera in Lasioglossum. This name has been applied to the majority of species with the metallic form, including the black one without complete lateral carina on the posterior surface of the propodeum (referred to as black Dialictus, acarinate, noncarinate or carinaless Evylaeus) in the Hemihalictus series (e.g., Michener 2000, 2007). On the other hand, Dialictus in the Palaearctic Region have been treated as the green Lasioglossum (Evylaeus) (Ebmer 2002; Pesenko 2007a). In the recent treatment of Lasioglossum, as outlined above, mostly metallic species in the Hemihalictus series are recognized as Dialictus (Gibbs et al. 2013). 420 L. (Dialictus) species are listed in the world (Ascher \& Pickering 2015, including Afrodialictus Pauly, 1984). Recently, L. (Dialictus) species from Canada and part of North America were revised by Gibbs $(2010,2011)$, who provided useful identification keys and good photographs of many specimens, whereas for those of eastern Asia (Russian Far East and eastern Siberia) only an identification key is available (Pesenko 2007b, as Evylaeus).

A further 10 species of Dialictus have been partially described or reported from Japan, the Korean Peninsula and/or Taiwan by various researchers (Japan: Ebmer \& Sakagami 1990; Ebmer et al. 1994; Murao \& Tadauchi 2008; Murao et al. 2006, 2009a; Usui et al. 1976. Korean Peninsula: Ebmer 1978. Taiwan: Strand 1913). No revisional study has been conducted to date in these countries. In the course of a collaborative study of the Asian Lasioglossum fauna, we examined the L. (Dialictus) specimens collected from Japan, the Korean Peninsula and Taiwan. Through our examination, we recognized $12 \mathrm{~L}$. (Dialictus) species in total for these countries. Among them, two new species were found from Taiwan 
MURAO R. et al., Dialictus of Japan, the Korean Peninsula, and Taiwan

and four known species were recorded from South Korea for the first time. In this paper, two new species from Taiwan are described and the remainder are redescribed or additionally described, and drawings, photographs and scanning electron micrographs for diagnostically important characters are provided. DNA barcodes of some species and an illustrated key of all species are presented to facilitate species identification in these countries.

\section{Material and method}

\section{Collection}

This study is based on the specimens deposited in the following institutions and personal collections, which are referred to using the following abbreviations:

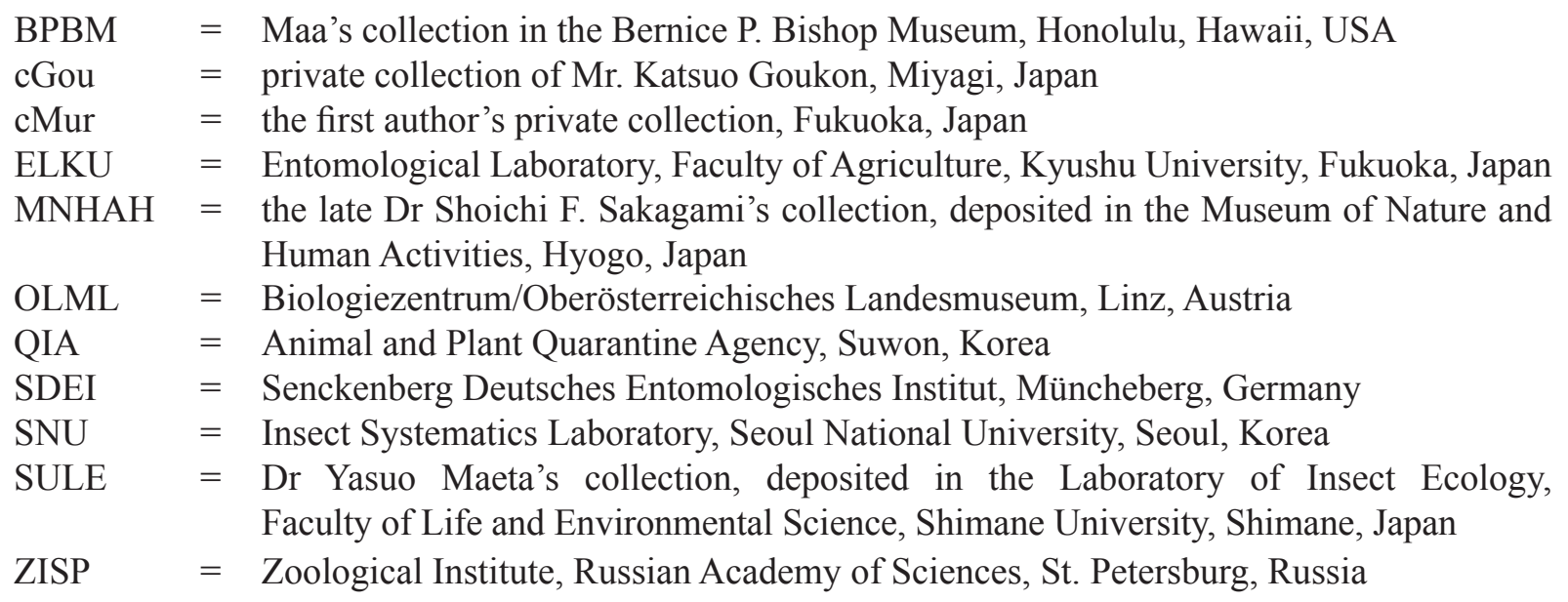

\section{Terminology}

Terminology and style used in the descriptions follow Murao et al. (2014). Abbreviations used in the text are as follows:

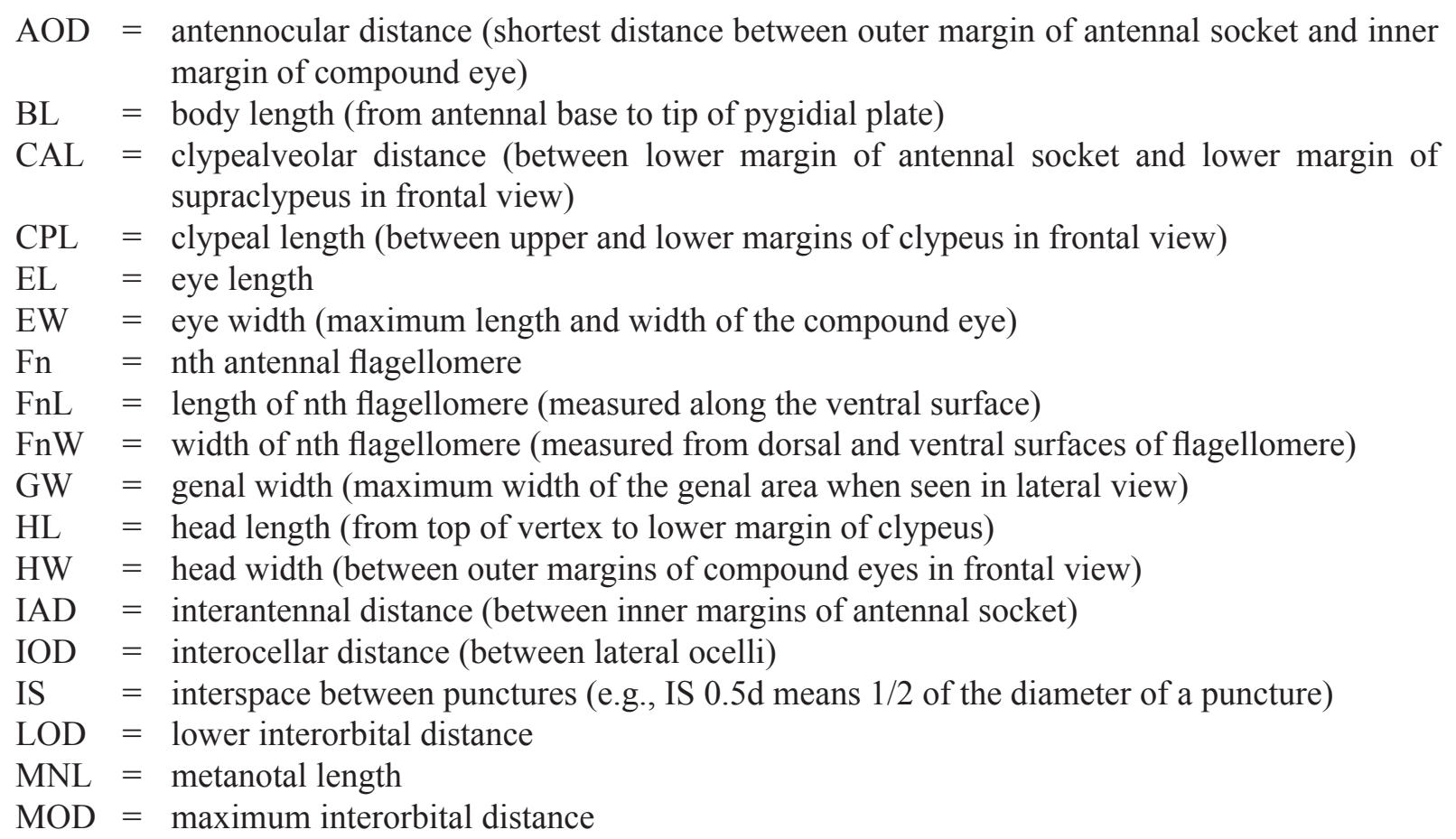




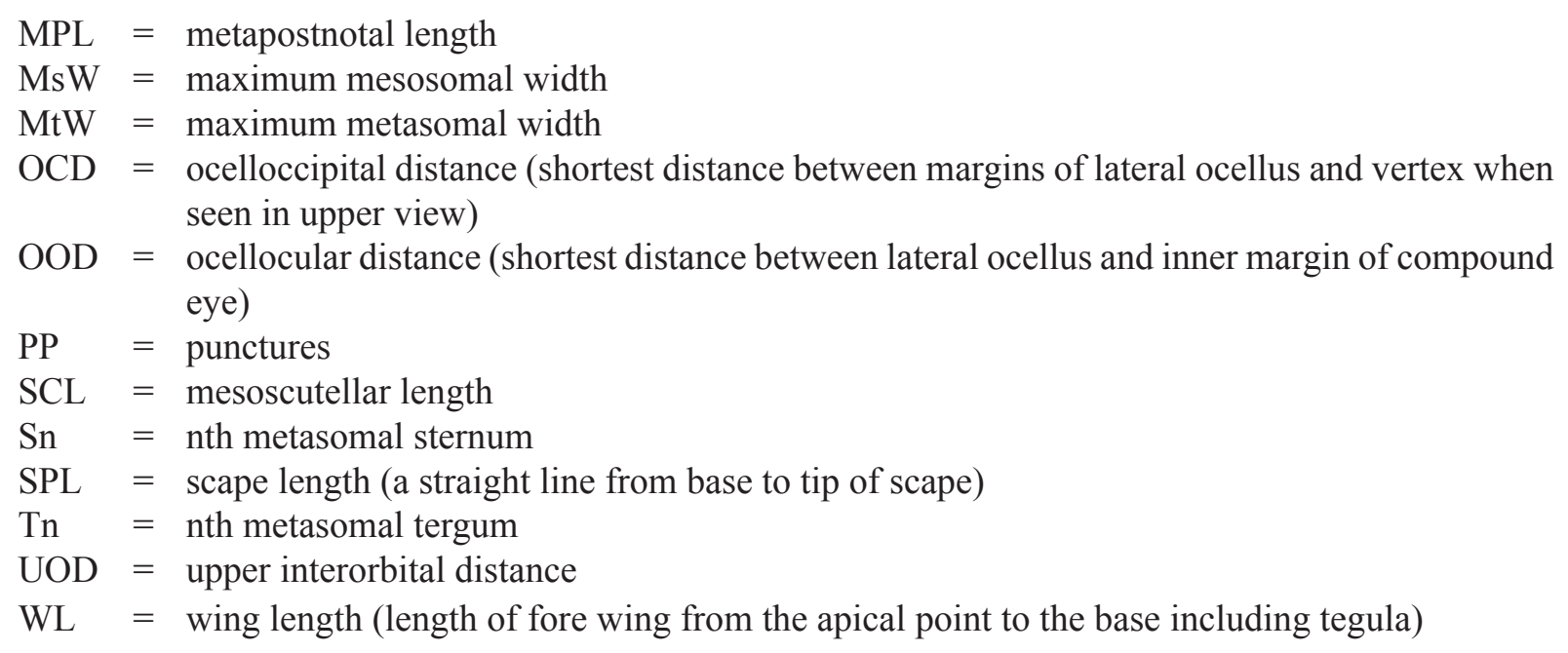

Body measurements are given in ranges followed by the average and standard deviation.

\section{Flower records}

Records of flowers visited by each species are based on specimen label data. The scientific names of flowering plants visited by bees are cited from Yonekura \& Kajita (2003-).

\section{DNA barcoding}

DNA extraction and PCR were conducted at the Kyushu University Museum (Fukuoka, Japan). DNA was extracted using a DNeasy Blood and Tissue Kit (Qiagen, Tokyo, Japan) following the manufacturer's instructions. A region of the cytochrome oxidase subunit I (COI) gene of mtDNA was amplified using polymerase chain reaction (PCR) with the primers LCO1490 (5'-GGTCAACAAATCATAAAGATATTGG-3') and HCO2198 (5'-TAAACTTCAGGGTGACCAAAAAATCA-3') (Folmer et al. 1994). Each PCR mixture contained $2 \mu 1$ of DNA template, $2.13 \mu 1$ of $10 \times$ EX Taq Buffer (Takara bio), $0.75 \mu 1$ of each primer $(20 \mu \mathrm{M}), 1.68$ $\mu 1$ of dNTP $(2.5 \mathrm{mM}$, Takara bio), and $0.25 \mu 1$ of EX Taq DNA polymerase (Takara bio). MilliQ water was added to reach a total reaction volume of $20 \mu \mathrm{l}$. PCR conditions were as follows: $94{ }^{\circ} \mathrm{C}$ for $1 \mathrm{~min}$, followed by 10 cycles of $94^{\circ} \mathrm{C}$ for $1 \mathrm{~min}, 48^{\circ} \mathrm{C}$ for $1 \mathrm{~min} 30 \mathrm{~s}$, and $72^{\circ} \mathrm{C}$ for $1 \min 30 \mathrm{~s}$, then 30 cycles at $94{ }^{\circ} \mathrm{C}$ for $1 \mathrm{~min}, 52^{\circ} \mathrm{C}$ for $1 \min 30 \mathrm{~s}, 72^{\circ} \mathrm{C}$ for $1 \mathrm{~min} 30 \mathrm{~s}$, and a final $72^{\circ} \mathrm{C}$ for $5 \mathrm{~min}$. PCR products were run on a $1 \%$ agarose gel for $20 \mathrm{~min}$, and then purified with $2.6 \mu \mathrm{l}$ of ExoSAP-IT (GE Healthcare Life Sciences). DNA sequencing was outsourced to the FASMAC Co., Ltd. (Kanagawa, Japan). The resulting sequences were aligned using the program MEGA (ver. 5; Tamura et al. 2011). The sequence data reported in the present paper are deposited at the DNA Data Base of Japan (DDBJ).

\section{Comparative material examined}

IRAN: Lasioglossum (Dialictus) aeratum (Kirby, 1802): $1 \hat{\partial}$, Kuhha-ye, Tu-Chal, N Iran, alt. 20002500 m, 18-19 Jul. 1970 (C. Elburz, MNHAH).

IRAN: Lasioglossum (Dialictus) algirum (Blüthgen, 1923): 1 §ิ, Kopet Dagh, $30 \mathrm{~km}$ N Quchan, Paßhöhe, alt. 2000 m, 18 Jul. 1977 (J. Gusenleitner, MNHAH).

IRAN: Lasioglossum (Dialictus) annulipes (Morawitz, 1876): 1 ภ, Kopet Dagh, $30 \mathrm{~km}$ N Quchan, Paßhöhe, alt. 2000 m, 18 Jul. 1977 (J. Gusenleitner, MNHAH).

AUSTRIA: Lasioglossum (Dialictus) leucopus (Kirby, 1802): 1 ô, Kärnten, Farchtnersee, 23 Aug. 1983 (J. Gusenleitner, MNHAH). 
MURAO R. et al., Dialictus of Japan, the Korean Peninsula, and Taiwan

CHINA: Lasioglossum (Dialictus) sanitarium (Blüthgen, 1926): 15 우, $4 \hat{\jmath} \widehat{\partial}$, Fukien, Chungan, Bohea Hill, 6 May 1938 (T.C. Maa, BPBM).

CHINA: Lasioglossum (Dialictus) sichuanense Fan \& Ebmer, 1992: 1 ㅇ (paratype), Omei, Sichuan

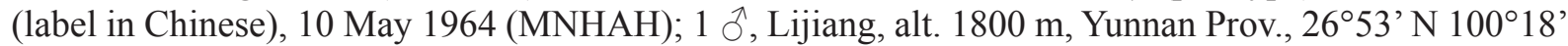
E, 23 Jun.-21 Jul. 1992 (S. Becvar, cMur).

CHINA: Lasioglossum (Dialictus) xizangense Fan \& Ebmer, 1992: 4 우, Fukien, Chungan, Bohea Hill, May 1938 (T.C. Maa, BPBM); 1 ô (paratype), Motuo, Xizang (label in Chinese), alt. 1300 m, 27 Nov. 1982 (Han Yin-heng, MNHAH).

\section{Results}

Class Hexapoda Blainville, 1816

Order Hymenoptera Linnaeus, 1758

Superfamily Apoidea Latreille, 1802

Epifamily Anthophila Latreille, 1804

Family Halictidae Thomson, 1869

Subfamily Halictinae Thomson, 1869

Tribe Halictini Thomson, 1869

Genus Lasioglossum Curtis, 1833

Lasioglossum (Dialictus) Robertson, 1902.

Paralictus Robertson, 1901: 229. Type species: Halictus cephalicus Robertson, 1892 (preoccupied by Morawitz 1873 = Halictus cephalotes Dalla Torre, 1896), by original designation.

Dialictus Robertson, 1902: 48. Type species: Halictus anomalus Robertson, 1892, by original designation and monotypy.

Chloralictus Robertson, 1902: 248. Type species: Halictus cressonii Robertson, 1890, by original designation.

Halictus (Gastrolictus) Ducke, 1902: 102. Type species: Halictus osmioides Ducke, 1902, by monotypy.

Halictomorpha Schrottky, 1911: 81. Type species: Halictomorpha phaedra Schrottky, 1911, by original designation.

Rhynchalictus Moure, 1947: 5. Type species: Rhynchalictus rostratus Moure, 1947, by original designation.

Halictus (Smeathhalictus) Warncke, 1975: 88. Type species: Melitta smeathmanella Kirby, 1802, by original designation.

Habralictellus Moure \& Hard, 1982: 46. Type species: Halictus auratus Ashmead, 1900, by original designation.

Lasioglossum (Afrodialictus) Pauly, 1984: 142. Type species: Halictus bellulus Vachal, 1909, by original designation.

Evylaeus (Viridihalictus) Pesenko, 2007a: 26. Type species: Halictus viridis Brullé, 1840, by original designation.

Evylaeus (Glauchalictus) Pesenko, 2007a: 26. Type species: Halictus problematicus Blüthgen, 1923, by original designation.

Evylaeus (Virenshalictus) Pesenko, 2007a: 26. Type species: Halictus virens Erichson, 1835, by original designation.

Evylaeus (Loethalictus) Pesenko, 2007a: 26. Type species: Halictus loetus Brullé, 1840, by original designation.

Evylaeus (Aerathalictus) Pesenko, 2007a: 27. Type species: Melitta aerata Kirby, 1802, by original designation. 


\section{Diagnosis}

This subgenus is usually separated from the other subgenera of Lasioglossum occurring in eastern Asia by having a combination of the head and mesosoma with brilliant or dull green-metallic luster in both sexes and the female fore wing with a weak second submarginal vein. In eastern Asia, the female of the
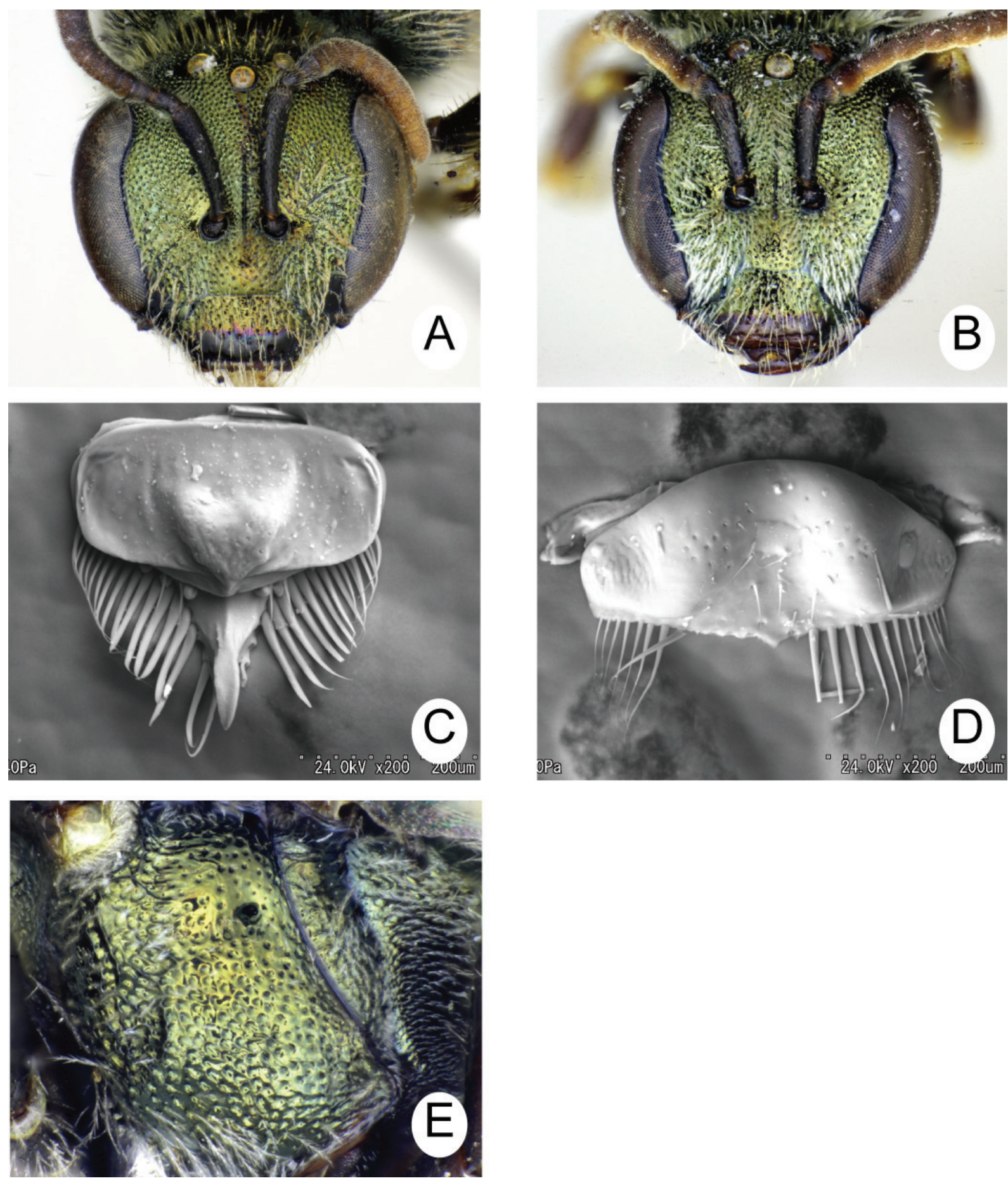

Fig. 1. A-E. Lasioglossum (Dialictus) viridellum (Cockerell, 1931). A-B. Head in frontal view. C-D. Labrum. E. Mesepisternum. A, C. ․ . B, D-E. Ô. 
MURAO R. et al., Dialictus of Japan, the Korean Peninsula, and Taiwan

apristum group belonging to L. (Sphecodogastra) (corresponding to the carinate L. (Evylaeus) in the dissenting classification (Ebmer 2002; Pesenko 2007a, as the genus Evylaeus)) has the same character states as L. (Dialictus). However, the members of this group can easily be separated from L. (Dialictus) in having the mesepisternum coarse reticulate-rugulose, the posterior surface of the propodeum with strong complete carina, and the inner hind tibial spur finely serrate.

\section{Comments}

As stated above, the green L. (Evylaeus) used by most Palaearctic researchers corresponds to L. (Dialictus) in the recent classification. Pesenko (2007a) re-classified Evylaeus sensu lato into 29 subgenera for the Palaearctic Region. In his systematic study, 6 of the subgenera (Aerathalictus Pesenko, Glauchalictus Pesenko, Loethalictus Pesenko, 2007, Smeathhalictus Warncke, 1975, Viridihalictus Pesenko, 2007 and Virenshalictus Pesenko, 2007) correspond to L. (Dialictus) as shown above in the synonymy list (synonymies by Gibbs 2010). These subgenera sensu Pesenko (2007a) are treated as a species group in this paper.

\section{The leucopus group}

Species included in eastern Asia:

L. aeratum (Kirby, 1802)

L. algirum (Blüthgen, 1923)

L. angaricum (Cockerell, 1937)

L. leucopus (Kirby, 1802)

L. meakanense Murao \& Tadauchi, 2009

L. pseudannulipes (Blüthgen, 1925)

L. viridellum (Cockerell, 1931)

Among the members of this group, both L. meakanense and L. pseudannulipes are known from Japan, and $L$. viridellum from the Korean Peninsula.

\section{Diagnosis}

Species of the leucopus group may be strictly characterized by a combination of the following character states: 1) male F2 short, approximately $1.2-1.5 \times$ as long as F1;2) mesepisternum reticulate-punctate on lower area in both sexes (Fig. 1E); 3) male metasomal sterna not modified (apical margin straight); 4) ventral retrorse lobe of male genitalia with moderately long setae only apically and distinct lineolation on surface (Fig. 2D, F-I).

The diagnostic characters of this group are also shown in Ebmer \& Sakagami (1990, as the leucopus group) and Pesenko (2007a, as subgenus Aerathalictus Pesenko, 2007).

\section{Distribution}

Palaearctic to northern Oriental Region.

\section{Comments}

This group is assumed to be monophyletic, based on the ventral retrorse lobe of male genitalia with moderately long setae only apically and the distinct lineolation on the surface. This character state may be unique within the subgenus. A comprehensive comparative study of the ventral retrorse lobe has not been performed for the subgenus, but this state may be an autapomorphy for the leucopus group. 

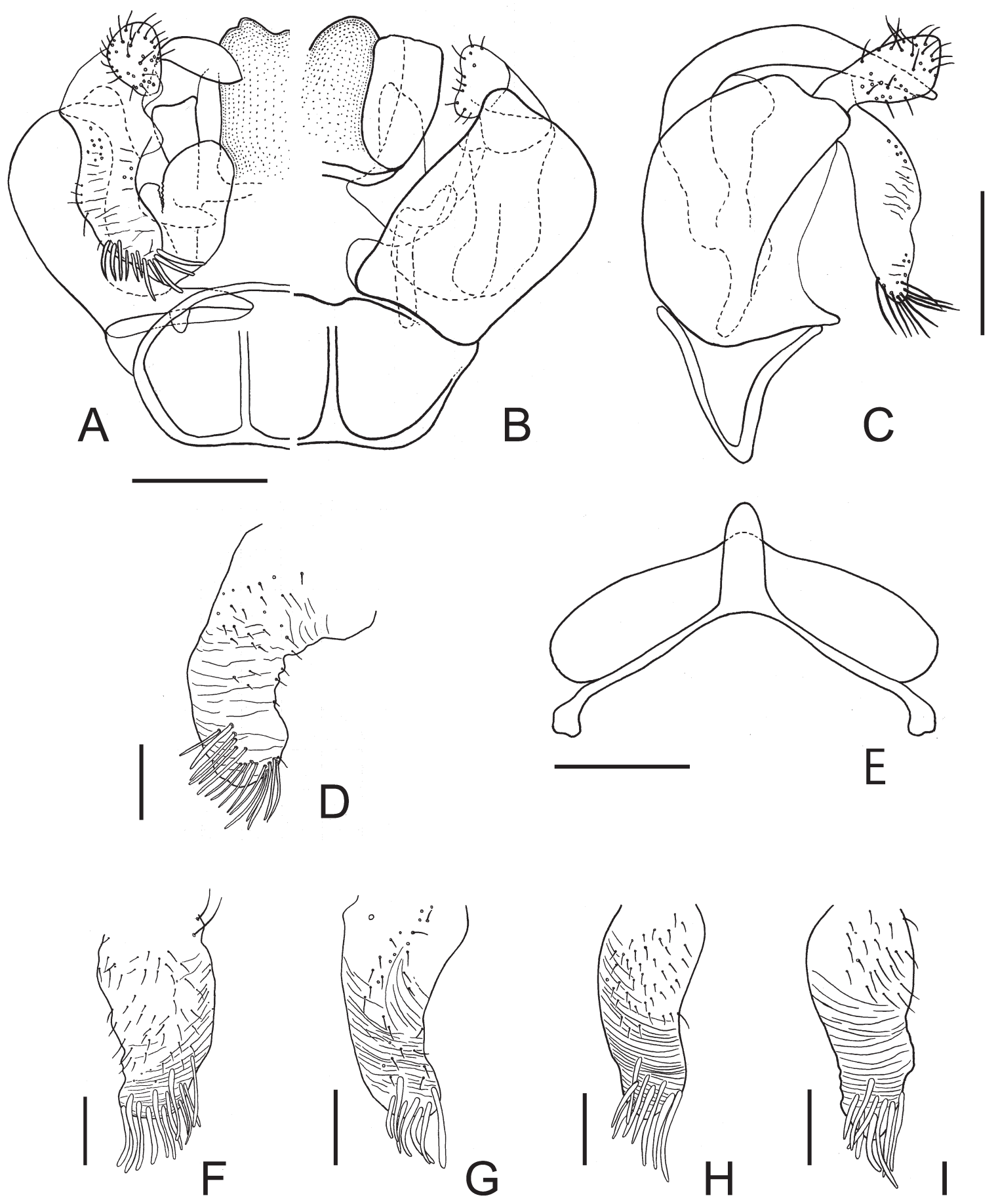

Fig. 2. - A-E. Lasioglossum (Dialictus) viridellum (Cockerell, 1931), O. — F. L. (D.) aeratum (Kirby,

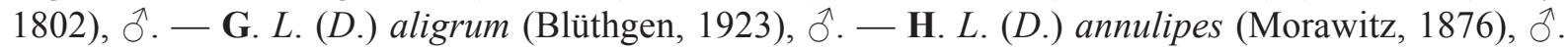
- I. L. (D.) leucopus (Kirby, 1802), ત̂. A. Genitalia in ventral view. B. Genitalia in dorsal view. C. Genitalia in lateral view. D, F-I. Ventral retrorse lobe of genitalia. E. S7-S8. Scale bars: A-C, E = 0.2 $\mathrm{mm}, \mathrm{D}, \mathrm{F}-\mathrm{I}=0.1 \mathrm{~mm}$. 
MURAO R. et al., Dialictus of Japan, the Korean Peninsula, and Taiwan

\section{Lasioglossum (Dialictus) pseudannulipes (Blüthgen, 1925)}

Figs 3A, 25B

Halictus pseudannulipes Blüthgen, 1925: 128 (holotype: Museum für Naturkunde Humboldt an der Universität zu Berlin, Germany, + ; type locality: Kwangtung Prov. (Guangdong Prov.), China).

Halictus pseudannulipes - Hirashima 1957: 16.

Lasioglossum (Evylaeus) algirum pseudannulipes - Ebmer 1978: 313. — Ebmer \& Sakagami 1990: 835-837.

Lasioglossum (Evylaeus) pseudannulipes - Murao et al. 2009a: 166-171 (ð).

\section{Diagnosis}

This species is similar to Lasioglossum angaricum (Cockerell, 1937) and L. viridellum (Cockerell, 1931) from eastern Asia in the leucopus group. It is separated from L. angaricum by the female T1 usually being without lineolation (sometimes T1 basally lineolate, but weaker than in L. angaricum) and the male sterna with sparse uniform hairs. In contrast, in L. angaricum the female $\mathrm{T} 1$ has distinct lineolation and the male S3-S5 is medially bare, laterally with tufts of long dense erect hairs (Pesenko 2007b). For the differences between females of this species and L. viridellum, see Key.

\section{Material examined}

JAPAN: Kyushu: 1 ㅇ, Matoishi wilderness, Aso-machi, Aso-shi, Kumamoto Pref., 37²7’15" N 1281'10” E, 14 Aug. 2010 (R. Murao, cMur); 8 우, Aso-shi, Kumamoto Pref., 330⒗115” N $131^{\circ} 8^{\prime} 5.658^{\prime \prime}$ E, 21 Jul. 2013 (R. Murao, cMur).

\section{Distribution}

China (Guangdong Prov.), Japan (Hokkaido, Honshu, and Kyushu).

\section{Flight records}

Female: April to October.

Male: June to October.

\section{Flower records}

Thirty-two species in 6 families were reported as floral hosts in Japan by Goubara et al. (2004).

\section{Habitat}

This species was collected from grassland in the Kumamoto Pref., Kyushu, western Japan. One of the collecting sites there is shown in Fig. 23B.

\section{DNA barcodes}

The COI gene sequences are deposited as DNA barcodes of $L$. (D.) pseudannulipes in the DDBJ under accession numbers LC027534 and LC027535. These numbers are also available in GenBank.

\section{Lasioglossum (Dialictus) viridellum (Cockerell, 1931)}

Figs 1, 2A-E, 3B

Halictus (Chloralictus) viridellus Cockerell, 1931: 14 (holotype: American Museum of Natural History, New York, USA, of; type locality: Shanghai, China).

Halictus (Chloralictus) viridellus - Hirashima 1957: 24. 
Lasioglossum (Evylaeus) viridellum - Ebmer 1978: 312-313 (ð). — Ebmer 1996: 283-284. — Ebmer 2006: 568.

Evylaeus (Aerathalictus) viridellus - Pesenko, 2007a: 27. — Pesenko 2007b: 85 (in key), 97 (in key), 114.

\section{Diagnosis}

This species is closely similar to Lasioglossum angaricum (Cockerell, 1937) and L. pseudannulipes (Blüthgen, 1925), as stated above. It is separated from L. angaricum by the disc of male sterna having sparse and uniform hairs. In contrast, in $L$. angaricum, the male S3-S5 are medially bare, laterally with tufts of long dense erect hairs (Pesenko 2007b).

\section{Material examined}

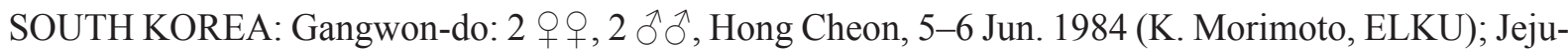
do, Jeju Is.: 11 우, Sanisu-dong Namjeju-gun, 23 Apr. 1997 (O. Tadauchi, ELKU); 1 ㅇ, Pijarim Forests Pukcheju-gun, 24 Apr. 1997 (O. Tadauchi, ELKU); 2 우, Kwangpyong-ri Namjeju-gun, 23 Apr. 1997 (O. Tadauchi, ELKU).

RUSSIA: 1 Oૈ, Primorsky Cray, 20 km SE of Spassk forest (label in Russian), 17 Jul. 1995 (Belokobylsky leg., ZISP).

\section{Additional description}

LABRUM (Fig. 1C-D). Basal area approximately $2.0 \times$ as wide as long in female; basal elevation moderately developed in both sexes, depressed centrally in male; distal process of female slender, nearly as long as basal area, and without lateral projection, that of male absent; keel of distal process narrow, apically pointed; labral fimbria acutely pointed at apex in both sexes. S7-S8 (Fig. 2E): S7 with moderately long, apex exceeding S8; S8 without median process.

MALE Genitalia (Fig. 2A-D). Gonobase flat at bottom, ventral arms connected with each other at upper ends; gonocoxite smooth, gently sloped in lateral view, inner and outer dorsal margins nearly parallel; gonostylus truncate apically in lateral view, located at top of gonocoxite, with sparse short hairs; ventral retrorse lobe long, reaching gonobase, with long and dense stetae apically (remaining parts with sparse short hairs) and distinct lineolation; penis valve higher than gonocoxite, without cleft on top.

\section{Distribution}

Russian Far East (Siberia, Khabarovsk, and Primorsky), China (Heilongjiang Prov., Shanghai), the Korean Peninsula (north, new record for south).

\section{Flight records}

Female: April to September.

Male: July to September.

\section{Flower records}

In South Korea, it was collected on the flowers of Potentilla hebiichigo Yonek. \& H. Ohashi (Rosaceae) and Brassica sp. (Brassicaceae).

\section{Comments}

Male specimens from Primorsky and South Korea are studied in the present paper, including characters of the labrum and genitalia. Through this examination, we have concluded that the males of both this species and L. pseudannulipes cannot be clearly separated. A female specimen of this species examined in this study shows weak lineolation on T1 basally (female T1 basally usually with strong lineolation as in Fig. 25A). The character state of this female specimen overlaps with some female specimens 
MURAO R. et al., Dialictus of Japan, the Korean Peninsula, and Taiwan

of L. pseudannulipes (see the description of Murao et al. 2009a). Lasioglossum viridellum and $L$. pseudannulipes could possibly represent the same species. It is difficult to resolve this, because we could not examine enough material of $L$. viridellum in this study. This problem needs to be addressed by including DNA analysis in a future study.

\section{Lasioglossum (Dialictus) meakanense Murao \& Tadauchi, 2009}

Figs 3A, 26A, 28B

Lasioglossum (Evylaeus) meakanensis Murao \& Tadauchi, 2009a (erroneous spelling): 113-117 (holotype: ELKU, ठ̊ ; type locality: Hokkaido, Japan).

\section{Diagnosis}

This species is separated from related species by the combination of the following characters: female supraclypeus with sparse PP (IS = 1-4.7), male labrum without basal elevation, and male S4-S5 (particularly S5) laterally with hair tufts that are longer than the surrounding hairs.

\section{Distribution}

Japan (Hokkaido). This species has only been collected from Mt. Meakan-dake in the eastern part of Hokkaido.

\section{Flight records}

Both sexes: August.

\section{Flower records}

Campanula lasiocarpa Cham. (Campanulaceae).
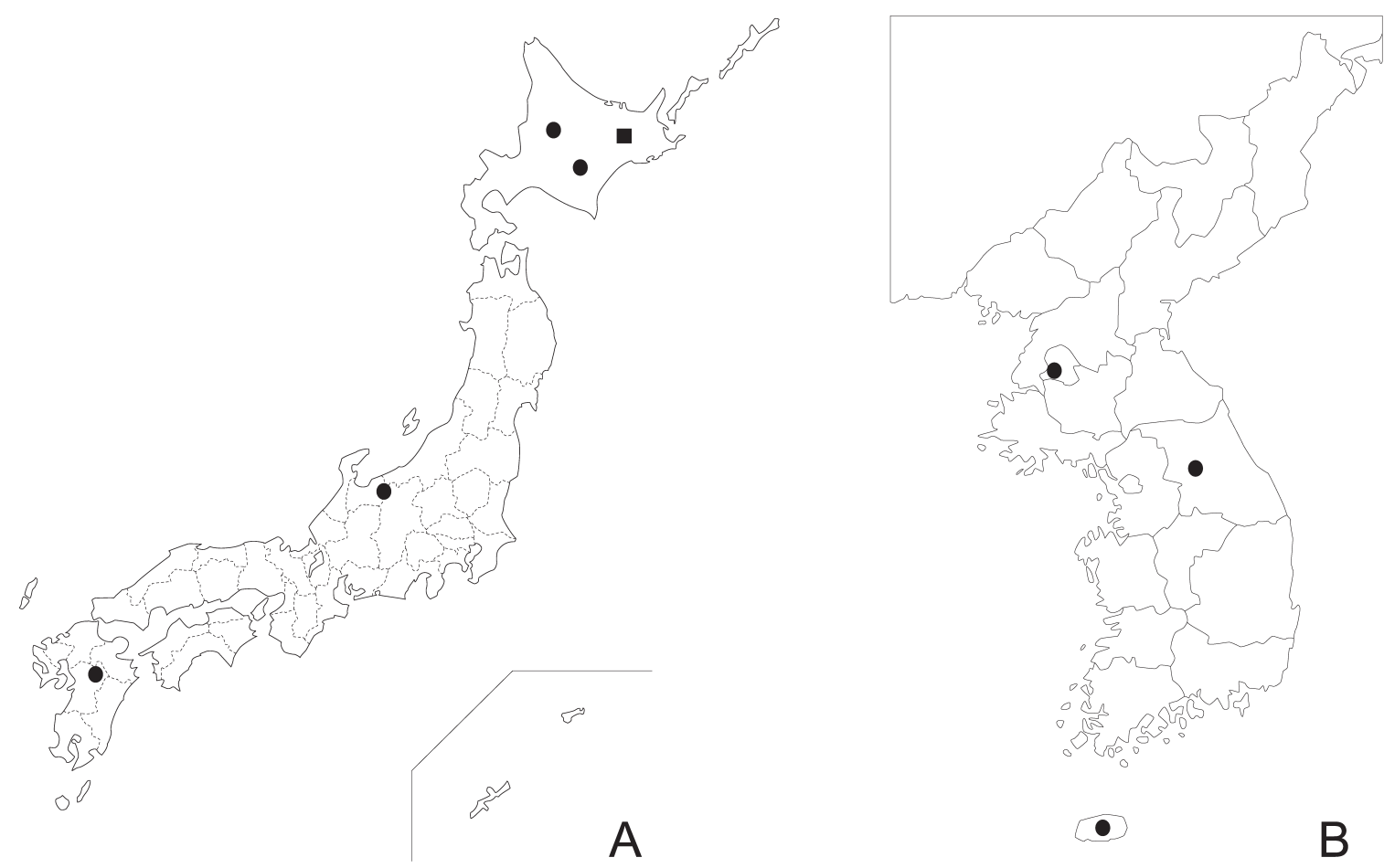

A

B

Fig. 3. Distribution maps. A. Lasioglossum (Dialictus) pseudannulipes (Blüthgen, 1925) and L. (D.) meakanense Murao \& Tadauchi, 2009 in Japan (•: L. pseudannulipes. .: L. meakanense). B. Lasioglossum (Dialictus) viridellum (Cockerell, 1931) in the Korean Peninsula. 


\section{The atroglaucum group}

Species included:

L. alishanense Murao sp. nov.

L. atroglaucum (Strand, 1913)

*L. callophrys Ebmer, 2002

${ }^{*}$ L. kintonense (Blüthgen, 1926)

*L. mystaphium Ebmer, 2002

L. negoroi Murao \& Tadauchi, 2008

L. problematicum (Blüthgen, 1923)

L. taiwanense Murao sp. nov.

L. sanitarium (Blüthgen, 1926)

*L. sauterum Fan \& Ebmer, 1992

L. sichuanense Fan \& Ebmer, 1992

*L. subversicolum Fan \& Ebmer, 1992

*L. versicolum Fan \& Ebmer, 1992

L. virideglaucum Ebmer \& Sakagami, 1994

L. yamanei Murao, Ebmer \& Tadauchi, 2006

The members of this group marked with an asterisk are tentatively included because the male has not yet been described. Seven species in total are known from the study area: three from Japan, one from Japan and the Korean Peninsula, and three from Taiwan.

\section{Diagnosis}

Species of the atroglaucum group may be strictly characterized by a combination of the following character states: 1) male F2 approximately $1.7-2.3 \times$ as long as F1;2) mesepisternum punctate over entire surface in both sexes (e.g., Fig. 6E); 3) male S4 or S5 modified, or with unique hair tufts as in Figs 4, 13-14; and 4) penis valve of male genitalia with high or low cleft on top (Figs 7C, 9C, 11C, 16C, 18C). The diagnostic characters of this group are also shown in Ebmer (2002) and Pesenko (2007a, as subgenus Glauchalictus Pesenko, 2007).

In addition, this group can be classified into two subgroups. The atroglaucum subgroup (L. atroglaucum, L. negoroi, L. taiwanense sp. nov., L. virideglaucum, and L. yamanei) is characterized by a combination of the male S5 with apical depression and without brush-like hairs (Fig. 5B, E, H, K, N), and the gonostylus of male genitalia without setae on the inner surface. The problematicum subgroup ( $L$. alishanense sp. nov., L. problematicum, L. sanitarium, and L. sichuanense) is characterized by the male $\mathrm{S} 5$ with brushlike hairs along apical margin (Figs 13, 14B, E, H) and the gonostylus of male genitalia with dense short setae on the inner surface (Fig. 16D). The latter subgroup can be regarded as a monophyletic group by the characters of the male S5 and genitalia. These character states are unique in the subgenus and are considered to be autapomorphies.

\section{Distribution}

This group is distributed from the Far East to southern Asia. It is diverse in the northern Oriental Region.

\section{Comments}

Lasioglossum miyabei Murao, Ebmer \& Tadauchi, 2006, L. pronotale Ebmer, 2002, and L. xizangense Fan \& Ebmer, 1992 are included as members of the atroglaucum group sensu Ebmer (2002) and Murao et al. (2006). These three species, however, do not share character states 3 ) and 4). They are considered to constitute another, separate group of its own. 
MURAO R. et al., Dialictus of Japan, the Korean Peninsula, and Taiwan

\section{The atroglaucum subgroup}

\section{Lasioglossum (Dialictus) atroglaucum (Strand, 1913)}

Figs 4A, 5A-C, 6, 7, 12A

Halictus atroglaucus Strand, 1913: 170 (holotype: SDEI, ô; type locality: Suisharyo, Formosa).

Halictus atroglaucus - Hirashima 1957: 5.

Lasioglossum (Evylaeus) atroglaucum - Ebmer 2002: 860-861.

\section{Diagnosis}

This species is easily separated from other members of the atroglaucum subgroup by the male $\mathrm{S} 4$ having dense and curly plumose hairs (Fig. 4A) and by the shape of the gonostylus (Fig. 7C).

\section{Material examined}

Holotype

TAIWAN: $\widehat{\partial}$ (Code No. DEIGISHym10517), Suisharyo, 11 Oct. (Sauter leg., SDEI).

\section{Additional material}

TAIWAN: 1 ô, Ya Kou, alt. 2800 m, Kao Hsiung Hsien, S-Taiwan, 1 Aug. 1986 (K. Baba, ELKU); 3 วิ ô, Yu Shih, (alt. 1900 m), Nao Tow Hsien, M-Taiwan, 4 Jul. 1986 (K. Baba, ELKU); 1 ô, Hehuanxi, 23 Jun. 1976 (H. Makihara, ELKU).

Measurements ( $\mathrm{n}=5$, unit $\mathrm{mm})$

$\mathrm{BL}=5.57-7.29(6.17 \pm 0.66), \mathrm{WL}=4.86-5.29(5.06 \pm 0.22), \mathrm{HL}=1.29-1.42(1.37 \pm 0.05), \mathrm{HW}=1.35-$ $1.39(1.38 \pm 0.01), \mathrm{IOD}=0.24-0.29(0.26 \pm 0.02), \mathrm{OOD}=0.23-0.26(0.24 \pm 0.01), \mathrm{OCD}=0.16-0.19$ $(0.18 \pm 0.01, \mathrm{n}=4), \mathrm{UOD}=0.84-0.87(0.85 \pm 0.02), \mathrm{MOD}=0.97-1.00(0.99 \pm 0.02), \mathrm{LOD}=0.50-0.58$ $(0.55 \pm 0.03), \mathrm{IAD}=0.19-0.23(0.21 \pm 0.01), \mathrm{AOD}=0.16-0.18(0.16 \pm 0.01), \mathrm{CAL}=0.23-0.27(0.25$ $\pm 0.02), \mathrm{CPL}=0.34-0.37(0.35 \pm 0.01), \mathrm{EL}=1.00-1.10(1.06 \pm 0.04), \mathrm{EW}=0.45-0.50(0.49 \pm 0.02), \mathrm{GW}$ $=0.25-0.35(0.30 \pm 0.04), \mathrm{SPL}=0.31-0.34(0.32 \pm 0.01), \mathrm{F} 1 \mathrm{~L}=0.13-0.16(0.14 \pm 0.01), \mathrm{F} 2 \mathrm{~L}=0.27-$ $0.29(0.28 \pm 0.01), \mathrm{F} 3 \mathrm{~L}=0.27-0.32(0.31 \pm 0.02), \mathrm{F} 2 \mathrm{~W}=0.13-0.16(0.15 \pm 0.01), \mathrm{MsW}=1.50-1.60$ $(1.55 \pm 0.06, \mathrm{n}=4), \mathrm{SCL}=0.34-0.38(0.36 \pm 0.02), \mathrm{MNL}=0.18-0.23(0.20 \pm 0.02), \mathrm{MPL}=0.30-0.34$ $(0.33 \pm 0.02), \mathrm{MtW}=1.00-1.15(1.07 \pm 0.07)$.

\section{Redescription}

Male

Coloration. Body black except for the following parts: head dark green and mesosoma metallic green; clypeus yellow on lower half; mandible reddish brown apically; flagellum blackish brown ventrally; tegula blackish brown translucent; tibial spur yellow; metasomal terga narrowly brown translucent apically. Wings transparent, veins and stigma brown.

PuBESCENCE. Body hairs whitish, and covered with erect and sparse fine, branched hairs except for the following parts: lower paraocular area with sparse tomentose; lower clypeus with sparse simple hairs; tibial and tarsal hairs nearly simple; disc of metasomal terga with sparse and simple short hairs; disc of S2-S3 apically with moderately dense fine, branched hairs; disc of S4 apically with dense and curly plumose hairs (Fig. 4A); disc of S5 with sparse short and simple hairs, mixed with sparse fine, branched hairs laterally; disc of S6 with sparse short and simple hairs.

HEAD. As long as wide; $\mathrm{HW}: \mathrm{HL}=1: 0.99$. Vertex rounded in frontal view. MOD:UOD:LOD = 1:0.86:0.56. IOD:OOD:OCD = 1:0.90:0.67. IAD:AOD = 1:0.76. Ocellocular and paraocular areas and frons dull, 
with reticulate PP. Supraclypeal area weakly convex, dull, with sparse PP, IS distinctly tessellate (IS $=1-4)$. CPL:CAL $=1: 0.72$. Clypeus nearly flat, with sparse PP, IS weakly tessellate (IS $=1-4.5$ ). $\mathrm{EW}: \mathrm{GW}=1: 0.61$. Genal area with straight ridges and distinct tessellation. Malar space linear. Occiput not carinate. Postgena weakly tessellate. Mandible edentate. Labrum (Fig. 6C) without basal elevation and distal process. Antenna long, reaching metasoma. F2L:F2W $=1: 0.54$; flagellum nearly flattened ventrally.

THORAX. Dorsolateral angle of pronotum obtuse; lateral surface without ridges; lateral lobe rounded. Tegula ovoid, nearly smooth. Mesoscutum (Fig. 6D) with moderately dense PP on marginal area,
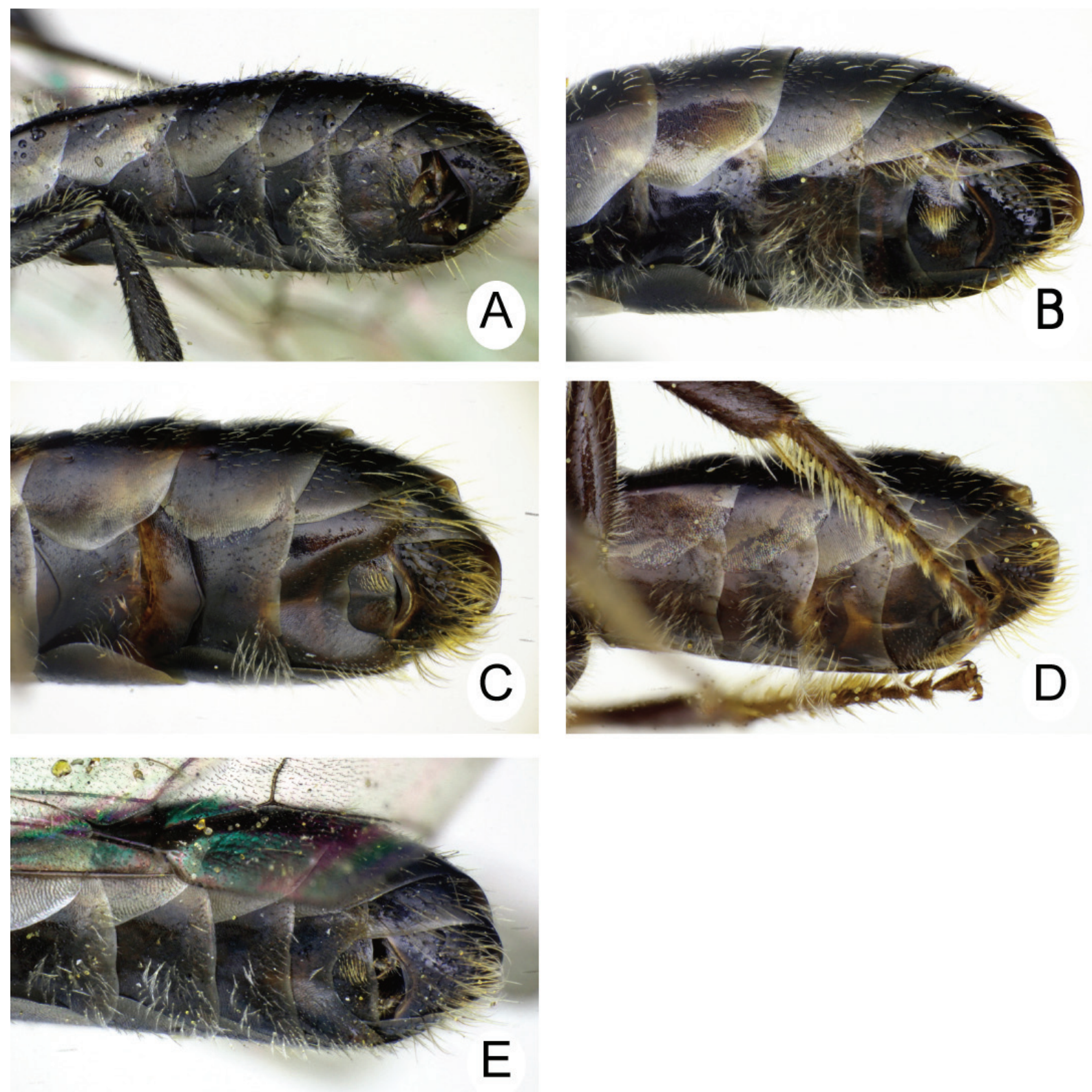

Fig. 4. Hairs on metasomal sterna in species of the atroglaucum subgroup, ${ }^{\lambda}$. A. Lasioglossum (Dialictus) atroglaucum (Strand, 1913). B. Lasioglossum (Dialictus) virideglaucum Ebmer \& Sakagami, 1994. C. Lasioglossum (Dialictus) yamanei Murao et al., 2006. D. Lasioglossum (Dialictus) negoroi Murao \& Tadauchi, 2008, holotype. E. Lasioglossum (Dialictus) taiwanense Murao sp. nov., holotype. 

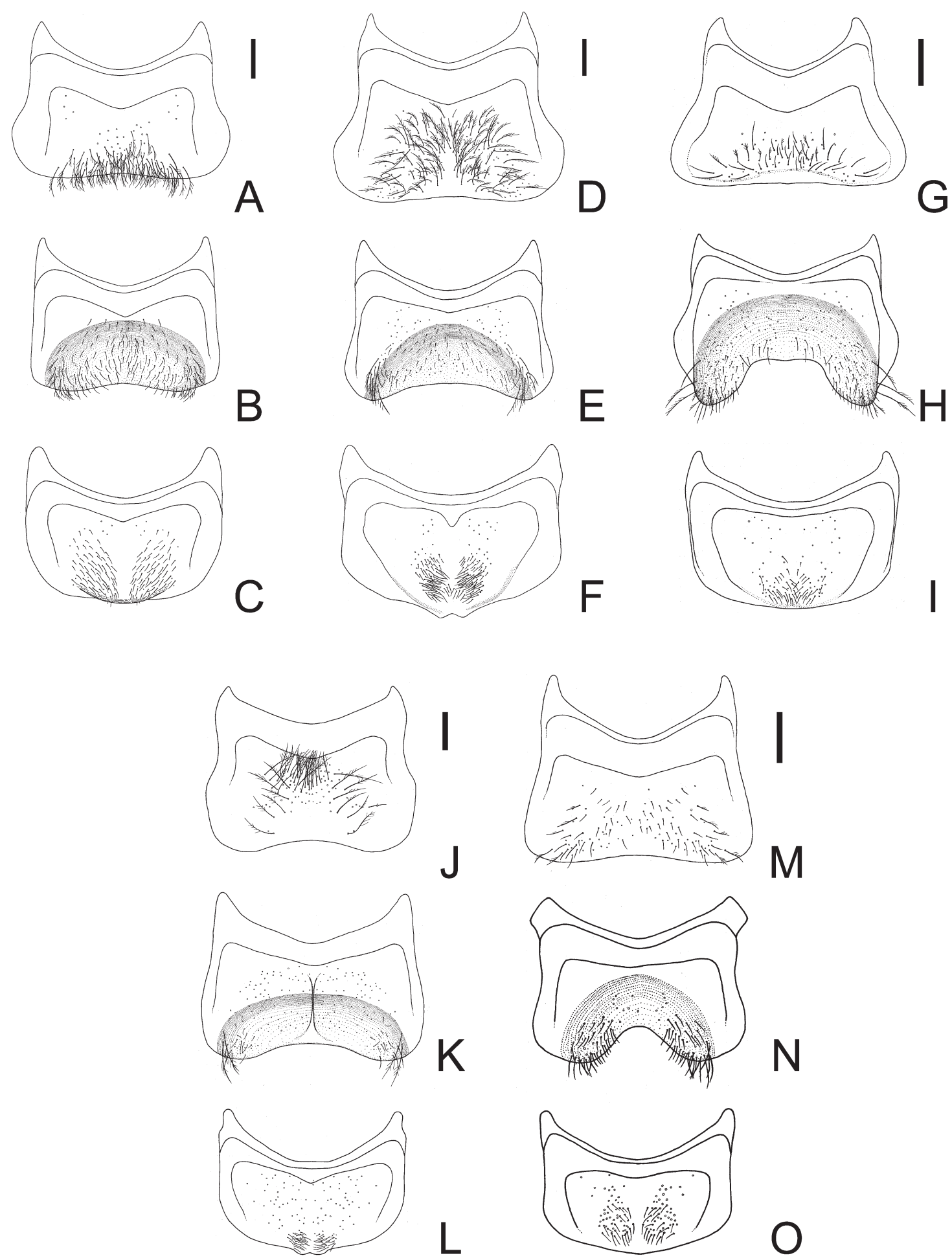

Fig. 5. S4-S6 in species of the atroglancum subgroup, ô. - A-C. Lasioglossum (Dialictus) atroglancum (Strand, 1913). - D-F. Lasioglossum (Dialictus) virideglaucum Ebmer \& Sakagami, 1994. - G-I. Lasioglossum (Dialictus) yamanei Murao et al., 2006 - J-L. Lasioglossum (Dialictus) negoroi Murao \& Tadauchi, 2008, paratype. - M-O. Lasioglossum (Dialictus) taiwanense Murao sp. nov., paratype. A, D, G, J, M: S4. B, E, H, K, N: S5. C, F, I, L, O: S6. Dotted area on S5 shows the apical depression. Scale bars: $0.2 \mathrm{~mm}$. 
gradually sparse toward anterior to medial areas; IS weakly tessellate anteriorly, but nearly smooth medially and posteriorly (IS $=0.5-2$ in marginal area, $1.5-4.5$ in anterior to medial areas); parapsidal line a narrow groove. Mesoscutellum with dense PP over entire surface, IS smooth (IS $=1-2)$. Metanotum weakly rugulose. Mesepisternum (Fig. 6E) shiny, with sparse PP over entire surface, IS smooth (IS = 1.5-6). SCL:MNL:MPL = 1:0.55:0.91. Propodeum: metapostnotum (Fig. 6F) gently inclined, with longitudinal ridges not reaching posterior margin; junction between metapostnotum and posterior surface
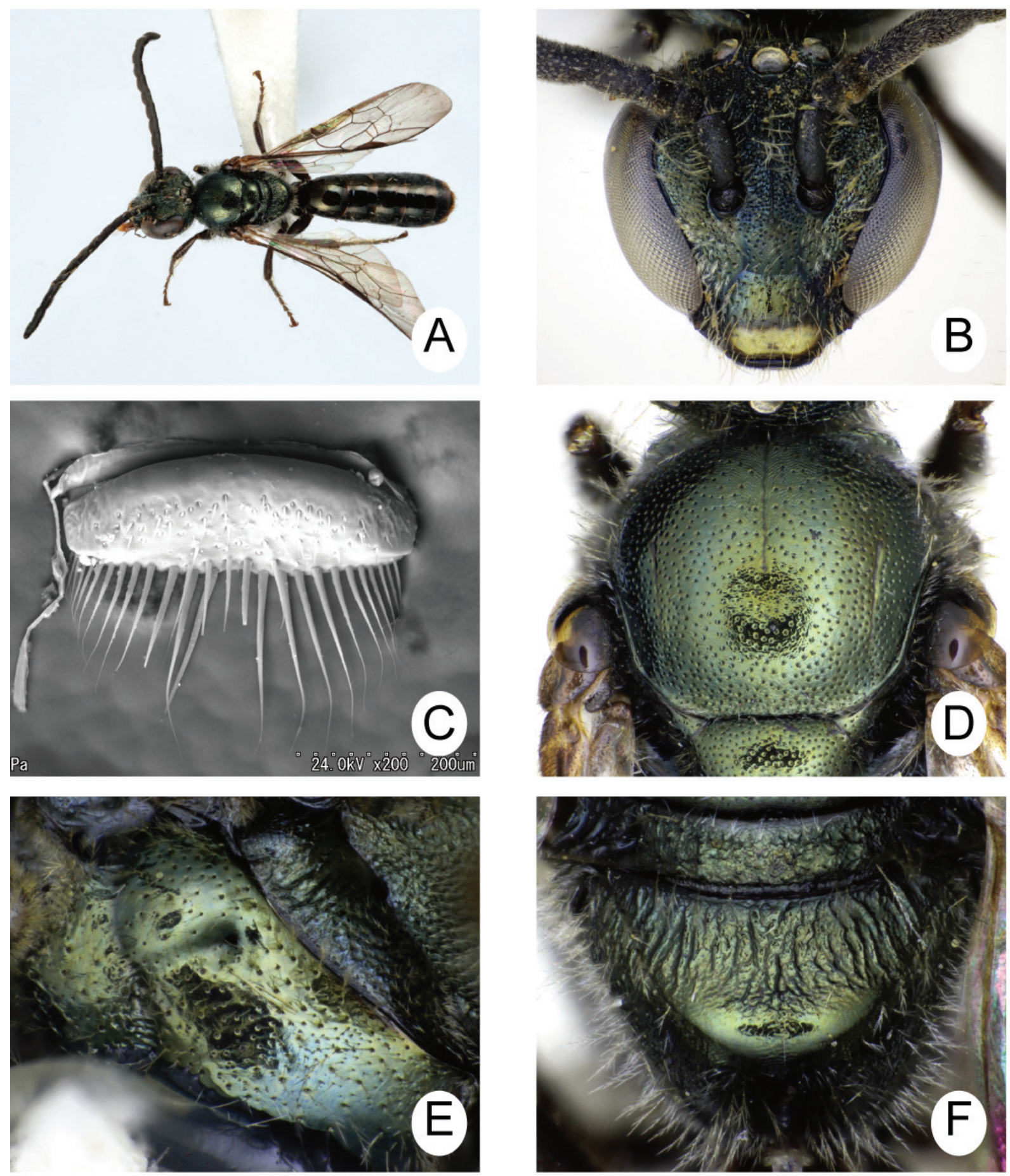

Fig. 6. Lasioglossum (Dialictus) atroglaucum (Strand, 1913), §. A. General habitus. B. Head in frontal view. C. Labrum. D. Mesoscutum. E. Mesepisternum. F. Metapostnotum. 
MURAO R. et al., Dialictus of Japan, the Korean Peninsula, and Taiwan

smooth, not carinate; lateral surface weakly rugulose; posterior surface with lateral carina on lower half, without oblique carina. Fore trochanter narrow, longer than wide. Hind tibia without basitibial plate. Hind basitarsus slender, approximately $4.6 \times$ as long as wide. Inner hind tibial spur finely serrate. Fore wing with three submarginal cells.

Abdomen. Discs of T1-T3 with sparse fine PP. T1 without lineolation. Lineolation on T2 basally, on T3-T5 over entire surface. Apical margin of S4-S6 nearly straight (Fig. 5A-C). S5 with shallow apical depression (Fig. 5B). S7-S8 (Fig. 7E): median process of S7 triangular, apex not exceeding S8; S8 without median process.

Genitalia (Fig. 7A-D). Gonobase flat at bottom, ventral arms not connected with each other at upper ends; gonocoxite smooth, gently sloped in lateral view, inner dorsal margin angulate at the approximately basal half; gonostylus small and thin, bud-like in lateral view, located on top of gonocoxite, and with
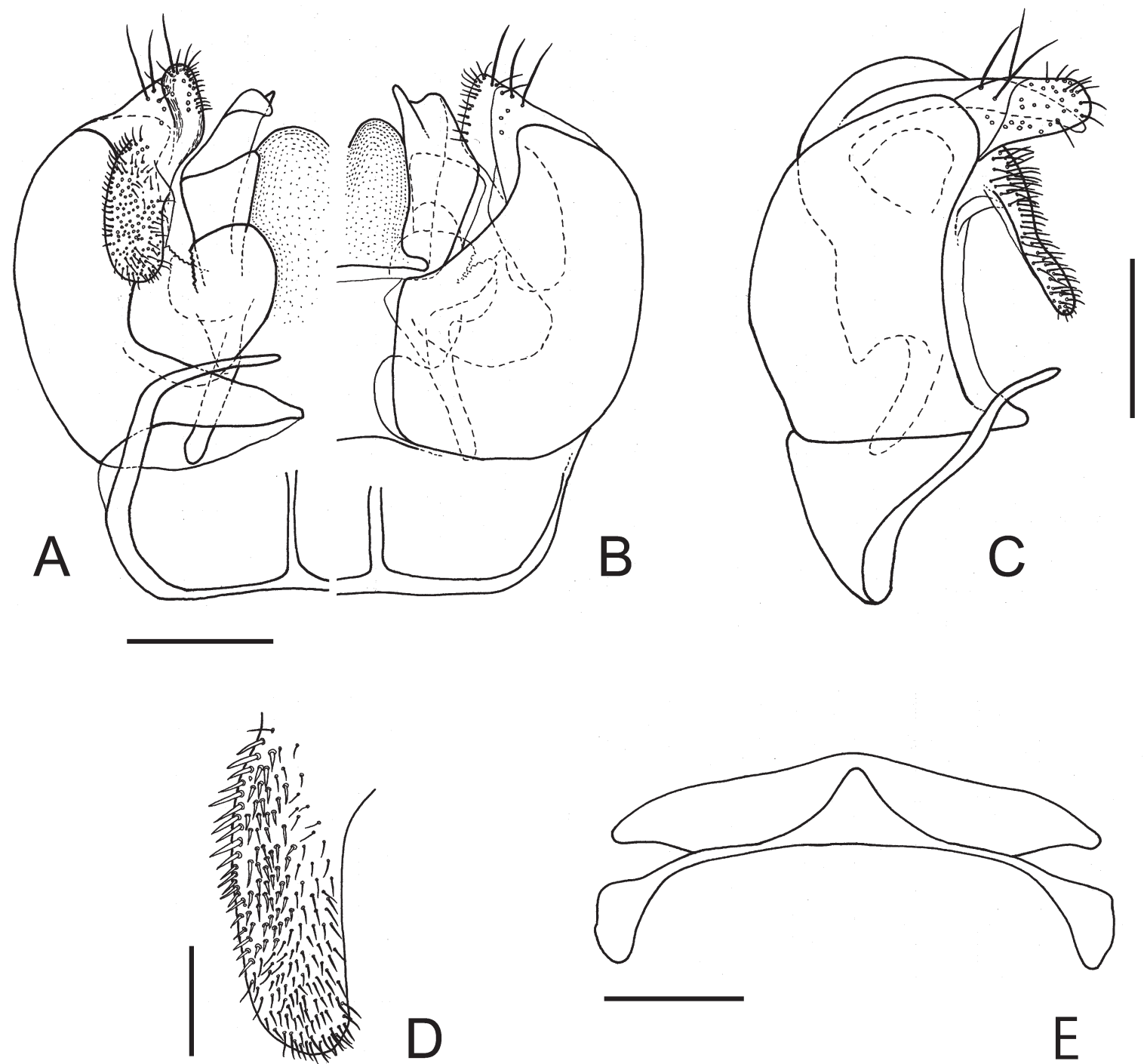

Fig. 7. Lasioglossum (Dialictus) atroglaucum (Strand, 1913), ô. A. Genitalia in ventral view. B. Genitalia in dorsal view. C. Genitalia in lateral view. D. Ventral retrorse lobe of genitalia. E. S7-S8. Scale bars: $\mathrm{A}-\mathrm{C}, \mathrm{E}=0.2 \mathrm{~mm}, \mathrm{D}=0.1 \mathrm{~mm}$. 
sparse short and a few relatively long hairs; ventral retrorse lobe tongue-like, moderately long but not reaching gonobase, with dense short setae; penis valve higher than gonocoxite, with low cleft on top.

Female

Unknown.

\section{Distribution}

Taiwan.

\section{Flight period}

Male: late June to early August.

\section{Flower records}

Not recorded.

Lasioglossum (Dialictus) virideglaucum Ebmer \& Sakagami, 1994 Figs 4B, 5D-F, 8, 9, 12B-C, 24B

Lasioglossum (Evylaeus) virideglaucum Ebmer \& Sakagami in Ebmer et al., 1994: 27-31 (holotype: Andreas Werner Ebmer's collection, Linz, Austria, ồ; type locality: Heishu, Yunnan Prov., China).

Lasioglossum (Evylaeus) virideglaucum - Ebmer 2002: 864-865. — Ebmer 2006: 564. — Murao et al. 2006: 50.

Evylaeus (Glauchalictus) virideglaucus - Pesenko 2007b: 85 (in key), 99 (in key), 115. — Pesenko 2007a: 26.

\section{Diagnosis}

This species is separated from the other members of the atroglaucum subgroup by a combination of the following characters: disc of male S4 with short and moderately dense hairs (Fig. 4B); male S6 with a pair of thin hair tufts (Fig. 4B); and the gonostylus of male genitalia nearly rounded on top (Fig. 9C).

\section{Material examined}

Paratypes

JAPAN: $2 \widehat{\partial} \widehat{\partial}$, Kosugidani-Hananoego, Yaku Is., Kagoshima Pref., 24 Jul. 1952 (Takeya \& Hirashima, MNHAH).

\section{Additional material}

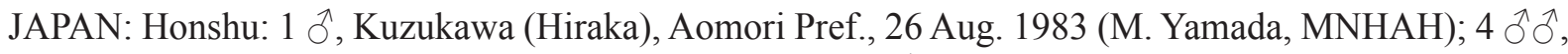
Ashiro, Iwate Pref., 19 Sep. 1976 (Y. Maeta, ELKU); 1 đ., Takeshikakami-honiri, Ueda-shi, Nagano Pref., 18 Sep. 2011 (R. Murao, cMur); 1 Ĵ, Arimine, Ôyama-machi, Toyama Pref., 6 Oct. 1993 (H.

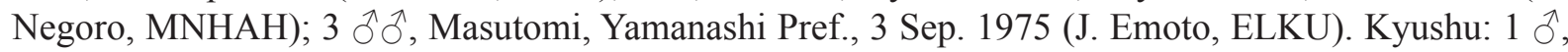
Mt. Hiko-san, Fukuoka Pref., 3 Oct. 1965 (S. Ibe, ELKU); Mt. Kujyu, alt. 1600-1700 m, Oita Pref.,

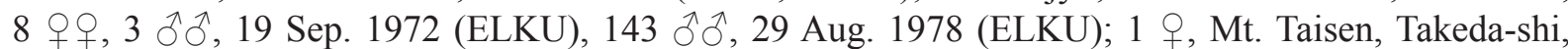
Oita Pref., 7-9 Jun. 1978 (ELKU); 2 q , Matoishi, Aso-machi, Aso-gun, Kumamoto Pref., 12 Sep. 2004 (T. Sugimoto, ELKU); 1 đૈ, Sobozan (Bungo), 9 Sep. 1933 (K. Yasumatsu, ELKU); 1 †, Mt. Sobo, Gokasho, Takachiho, Miyazaki Pref., 27 Apr. 2003 (O. Tadauchi, ELKU); 2 ổ ô, KosugidaniHananoego, Yaku Is., Kagoshima Pref., 24 Jul. 1952 (Takeya \& Hirashima, ELKU).

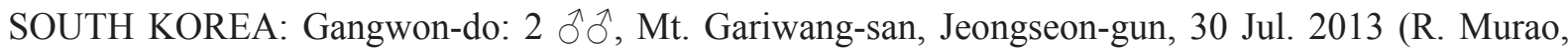
cMur); Bukdaesa temple, Mt. Odae-san, Jinbumyeon, Pyeongchang-gun, 3 $\widehat{\jmath} \widehat{\jmath}, 3$ Sep. 1998 (H.S. Lee, 


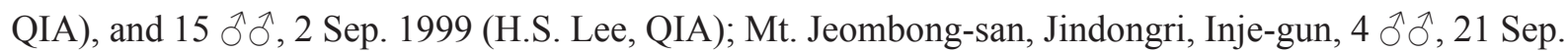

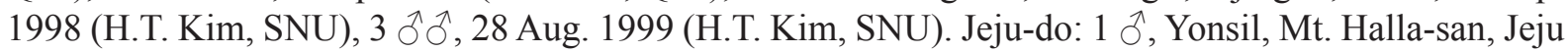
Is., 27 Jul. 1990 (O. Tadauchi, ELKU).

\section{Additional description}

LABrum (Fig. 8C-D). Basal area approximately $2.6 \times$ as wide as long in female, $3 \times$ in male; basal elevation of female moderately developed, that of male absent; distal process of female slender, nearly as long as basal area, and without lateral projection, that of male absent; keel of distal process narrow, apically pointed in female; labral fimbria acutely pointed at apex in both sexes.

STERNA. S4 and S6 normal shaped, not modified. S7-S8 (Fig. 9E): S7 with long, apically rounded median process, apex exceeding S8; S8 without median process.

Male Genitalia (Fig. 9A-D). Gonobase nearly flat at bottom, ventral arms connected with each other at upper ends; gonocoxite smooth, gently sloped in lateral view, and inner dorsal margin angulate at approximately basal 1/3; gonostylus large, located at top of gonocoxite, with sparse short and moderately long hairs; ventral retrorse lobe moderately long but not reaching gonobase, with moderately dense short setae ventrally; penis valve higher than gonocoxite, with low cleft on top.
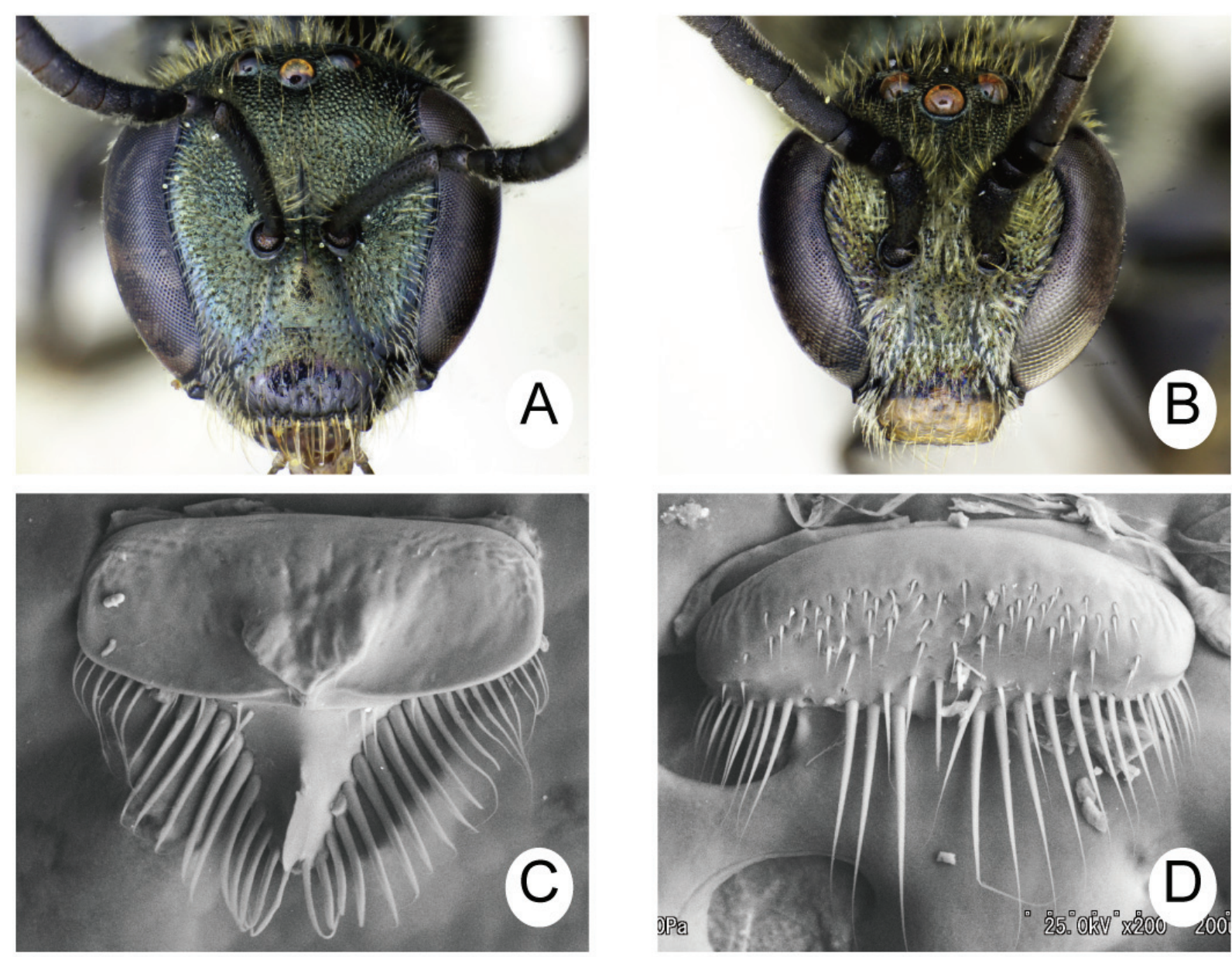

Fig. 8. Lasioglossum (Dialictus) virideglaucum Ebmer \& Sakagami, 1994. A-B. Head in frontal view. C-D. Labrum. A, C. ‥ B, D. ○̂. 


\section{Distribution}

Russian Far East (Primorsky, Khabrovsk), the Korean Peninsula (new record), Japan (Honshu, Shikoku, Kyushu, Yaku Is.), China (Sichuan, Shanxi, Yunnan Provs.). While conducting our study, the male of this species was found from several localities in South Korea (the female cannot be clearly separated from that of some related species such as L. problematicum). On the Korean Peninsula, Lasioglossum problematicum has been recorded from North Korea based on female specimens (Ebmer 1978). Pesenko (2007b) regarded the continental records of $L$. problematicum as L. virideglaucum. Our results support Pesenko's opinion. It might be prudent to remove L. problematicum from the Korean fauna.
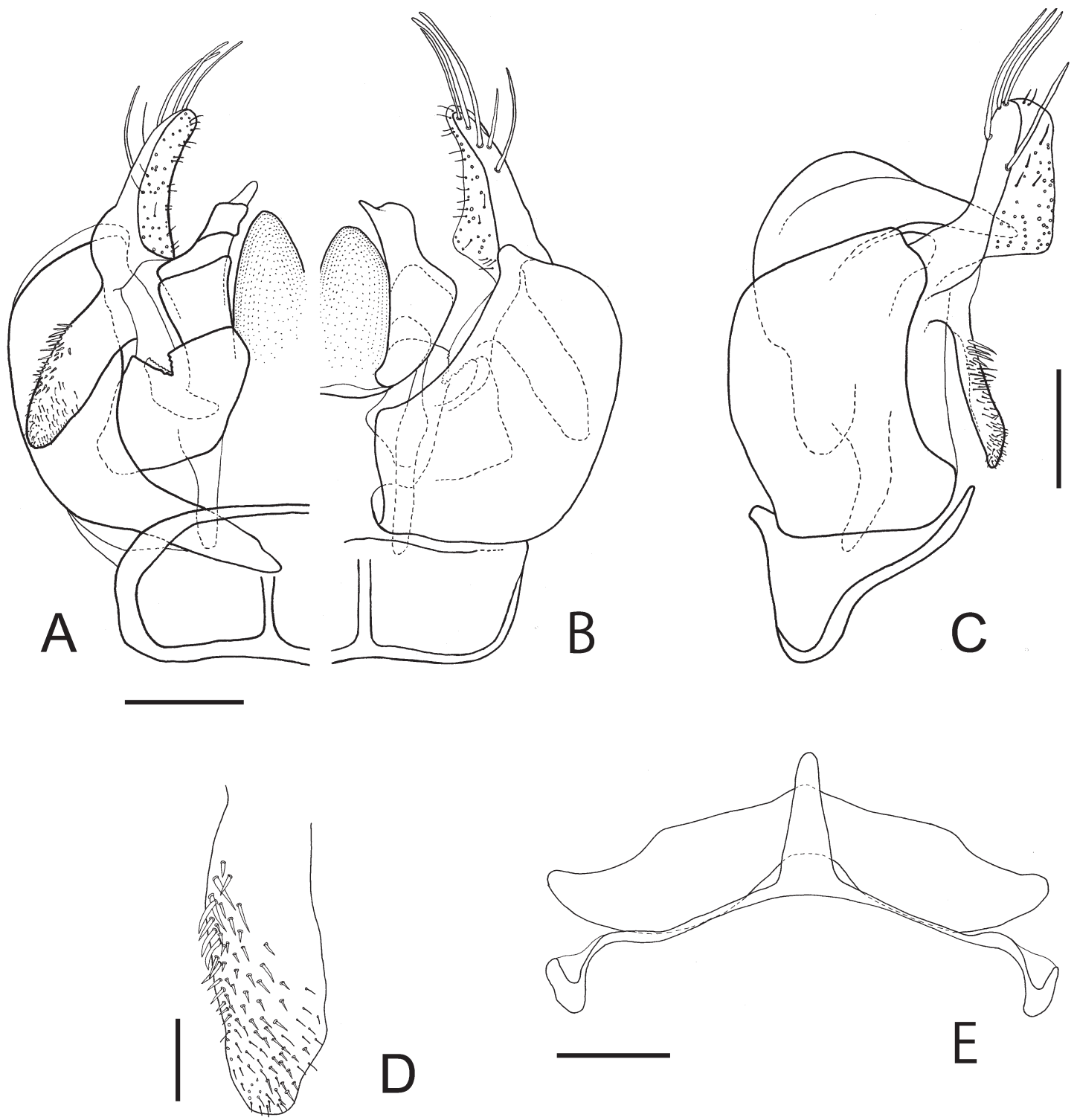

Fig. 9. Lasioglossum (Dialictus) virideglaucum Ebmer \& Sakagami, 1994, ふ̃. A. Genitalia in ventral view. B. Genitalia in dorsal view. C. Genitalia in lateral view. D. Ventral retrorse lobe of genitalia. E. S7-S8. Scale bars: A-C, E = $0.2 \mathrm{~mm}, \mathrm{D}=0.1 \mathrm{~mm}$. 
MURAO R. et al., Dialictus of Japan, the Korean Peninsula, and Taiwan

\section{Flight period}

Female: April to September in Kyushu, Japan.

Male: August to October.

The flight record of the female is based on specimens collected from Kyushu, Japan, because one of the related species, $L$. problematicum, does not sympatrically inhabit this area.

\section{Flower records}

The specimens examined in this paper were collected on the flowers of Aster var. ovatus (Franch. \& Sav.) Soejima \& Mot. Ito (Asteraceae), Bellis perennis L. (Asteraceae), Brassica napus L. (Brassicaceae), Cimicifuga simplex (DC.) Wormsk. ex Turcz (Ranunculaceae), Isodon inflexus (Thunb.) Kudô (Lamiaceae), Persicaria sp. (Polygonaceae), Senecio cannabifolius Less. (Asteraceae), and Solidago virgaurea L. subsp. asiatica (Nakai ex H. Hara) Kitam. ex H. Hara var. asiatica Nakai ex H. Hara (Asteraceae). The other floral records in Japan belong to 12 species in 4 families (Negoro 2012).

\section{Habitat}

This species has been collected in mountainous areas in Japan and South Korea. The collecting sites are shown in Fig. 23 A, C (A = Nagano Pref., Japan; C = Mt. Gariwangsan, South Korea).

\section{DNA barcodes}

The COI gene sequences are deposited as DNA barcodes of $L$. (D.) virideglaucum in the DDBJ under accession numbers LC027537 and LC027538. These numbers are also available in GenBank.

Lasioglossum (Dialictus) yamanei Murao, Ebmer \& Tadauchi, 2006

Figs 4C, 5G-I, 12D

Lasioglossum (Evylaeus) yamanei Murao, Ebmer \& Tadauchi, 2006: 46-49 (holotype: ELKU, + ; type locality: Ibaraki Pref., Japan).

Evylaeus (Glauchalictus) yamanei - Pesenko 2007a: 26.

\section{Diagnosis}

This species is separated from the other members of the atroglaucum subgroup by a combination of the following characters: disc of male S4 with sparse hairs (Fig. 4C); male S5 deeply $\cap$-shaped apically (Figs 4C, 5H); and gonostylus of male genitalia large, obliquely truncated in lateral view (Murao et al. 2006, Fig. 11B). It may be closely related to L. taiwanense Murao sp. nov. from Taiwan in sharing the male S5 without a groove, the apical margin of male S5 incurved, and the ventral retrorse lobe of male genitalia short.

\section{Material examined}

JAPAN: Honshu: 1 , Ohokawara, Aomori Pref., 28 Jun. 1992 (K. Goukon, cGou); 2 우, Tomiyacho, Miyagi Pref., 19 Apr. 2009 (K. Goukon, cGou); 1 + , Nishikawa-cho, Yamagata Pref., 15 Jul. 2001 (K. Goukon, cGou); 2 ổ, Ogawa, Saitama Pref., 15 Sep. 1971 (T. Nambu, ELKU); 1 ô, Mt. Mitake, Tokyo Pref., 12 Sep. 1964 (H. Suda, ELKU). Shikoku: 1 O), Monobe village, Kochi Pref., 23 Sep. 1971 (S. Ikudome, ELKU). Kyushu: 1 đૈ, Mizunashi (Chikuzen), Fukuoka Pref., 15 Sep. 1935 (K. Yasumatsu,

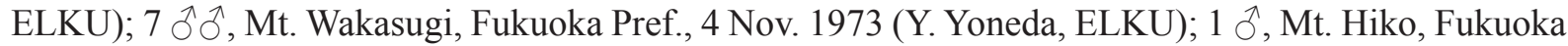
Pref., 16 Aug. 1973 (Y. Yoneda, ELKU); 2 q, 1 ภ, Matoishi wilderness, Aso-shi, Kumamoto Pref., 3255’46.305” N 13058’11.555” E, 5 Aug. 2013 (Y. \& R. Murao, cMur); 1 ô, Mt. Sobo, Nishiusuki, Miyazaki Pref., 29 Jun. 1985 (K. Kusumoto, ELKU). 


\section{Distribution}

Japan (Honshu, Shikoku, Kyushu), China (Zhejiang Prov.).

\section{Flight period}

Female: April to October.

Male: June to November.

\section{Flower records}

Twelve species in 5 families were reported as the floral records in Japan by Goubara et al. (2004, as Lasioglossum sp. 3), 15 species in 9 families by Murao et al. (2006), and 9 species in 7 families by Negoro (2012). The total number of species is 36 in 13 families as follows. Apiaceae: Angelica polymorpha Maxim.; A. spp.; Osmorhiza aristata (Thunb.) Rydb. Asteraceae: Aster ageratoides Turcz. var. ageratoides; A. glehnii F.Schmidt var. glehnii; Erigeron annuus (L.) Pers.; Ixeridium dentatum (Thunb.) Tzvelev subsp. dentatum; Lactuca indica L.; Solidago virgaurea L. subsp. asiatica (Nakai ex H. Hara) Kitam. ex H. Hara var. asiatica Nakai ex H. Hara; Solidago virgaurea L. subsp. leiocarpa (Benth.) Hultén; Taraxacum officinale Weber ex F.H. Wigg. Brassicaceae: Brassica rapa L. var. oleifera DC.; Capsella bursa-pastoris (L.) Medik.; Cardamine leucantha (Tausch) O.E. Schulz; Eutrema tenue (Miq.) Makino. Caryophyllaceae: Stellaria sessiliflora Y. Yabe. Ericaceae: Elliottia paniculata (Siebold \& Zucc.) Hook.f. f. albiflora (Y. Kimura) Yonek. Geraniaceae: Geranium sp.; G. thunbergii Siebold ex Lindl. et Paxton. Lamiaceae: Mosla dianthera (Buch.-Ham. ex Roxb.) Maxim. Liliaceae: Allium thunbergii G. Don. Polygonaceae: Persicaria thunbergii (Siebold et Zucc.) H. Gross. Ranunculaceae: Ranunculus japonicus Thunb. Rosaceae: Geum japonicum Thunb.; Potentilla fragarioides L. var. major Maxim.; P. freyniana Bornm.; P. hebiichigo Yonek. \& H. Ohashi; Rubus palmatus Thunb.; R. parvifolius L. Salicaceae: Salix spp. Violaceae: Viola obtusa Makino; V. rostrata Pursh.

\section{Habitat}

This species has been collected in mountain areas in Japan. One of the collecting sites in Japan (Kumamoto Pref., Kyushu) is shown in Fig. 23B.

Lasioglossum (Dialictus) negoroi Murao \& Tadauchi, 2008

Figs 4D, 5J-L, 12E

Lasioglossum (Evylaeus) negoroi Murao \& Tadauchi, 2008: 37-40 (holotype: ELKU, ô; type locality: Toyama Pref., Japan).

\section{Diagnosis}

This species is separated from other members of the atroglancum subgroup by a combination of the following characters: male S4 basally with sparse and moderately long erect hairs (Murao \& Tadauchi 2008; Fig. 2H); male S5 with a linear shallow groove (Fig. 5K); male S6 with a pair of thin hair tufts; and gonostylus of male genitalia truncated on top (Murao \& Tadauchi 2008; Fig. 2B-C).

\section{Material examined}

Holotype

JAPAN: ơ (Code No. ELKU3261), Kobo, Tateyama, Toyama Pref., Honshu, 10 Sep. 1997 (H. Negoro, ELKU).

\section{Paratype}

JAPAN: 1 ठ, Koganeyu, Minami-ku, Sapporo-shi, Hokkaido (label in Japanese), 18 Sep. 2004 (K. Kinota, ELKU). 
MURAO R. et al., Dialictus of Japan, the Korean Peninsula, and Taiwan

\section{Additional material}

JAPAN: Honshu: 1 ðૈ, Nikko-Yumoto (Shimozuke), 15 Aug. 1937 (T. Esaki \& K. Yasumatsu, ELKU);

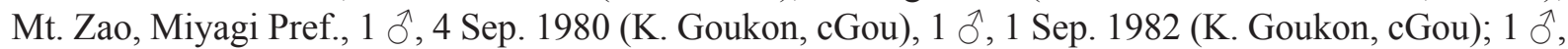
Mt. Zao, alt. 1300 m, Miyagi Pref., 28 Sep. 1996 (K. Goukon, cGou).

\section{Female}

Unknown.

\section{Distribution}

Japan (Hokkaido, northern and central Honshu).

\section{Flight period}

Male: August to October.

\section{Flower records}

Araliaceae: Aralia continentalis Kirag.. Asteraceae: Aster microcephalus (Miq.) Franch. \& Sav. var. ovatus (Franch. \& Sav.) Soejima \& Mot. Ito; Solidago virgaurea L.

Lasioglossum (Dialictus) taiwanense Murao sp. nov. urn:Isid:zoobank.org:act:C164E332-E591-4C50-A4BD-9E4C208276B8

Figs $4 \mathrm{E}, 5 \mathrm{M}-\mathrm{O}, 10,11,12 \mathrm{~A}$

\section{Diagnosis}

This species is separated from other members of the atroglaucum subgroup by a combination of the following characters: male head wider than long; disc of male S4 with sparse and short hairs (Fig. 4E); male S5 gently incurved apically (Fig. 5N); and the shape of gonostylus of male genitalia (Fig. 11C-D).

\section{Etymology}

The specific name is derived from the type country, Taiwan.

\section{Material examined}

\section{Holotype}

TAIWAN: §’, Hehuanxi, Songguangang, Nantou Pref., 24 Jun. 1976 (H. Makihara, ELKU).

\section{Paratypes}

TAIWAN: 4 ठ̊ ô, Meishan-Tinchi (alt. 800-2300 m), Kao Hsiung Hsien, S-Taiwan, 29 Jun. 1986 (K. Baba, ELKU); 2 §ึ, Pi Lu Chih, alt. 2500 m, Nan Tow Hsien, M-Taiwan, 5 Aug. 1986 (K. Baba,

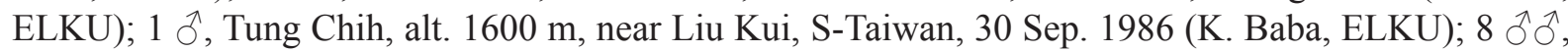
Hehuanxi, Songguangang, Nantou Pref., 24 Jun. 1976 (H. Makihara, ELKU); 3 $\widehat{\partial}$, Hehuanxi, 23 Jun.

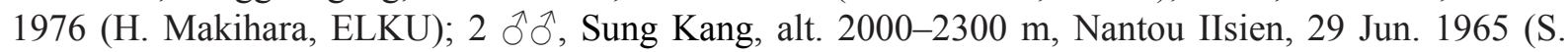
Kimoto, ELKU).

$$
\begin{aligned}
& \text { Measurements }(\mathrm{n}=10, \text { unit } \mathrm{mm}) \\
& \mathrm{BL}=5.29-6.00(5.65 \pm 0.32), \mathrm{WL}=4.43-5.14(4.91 \pm 0.25), \mathrm{HL}=1.26-1.40(1.32 \pm 0.06), \mathrm{HW}= \\
& 1.32-1.45(1.37 \pm 0.05), \mathrm{IOD}=0.19-0.26(0.24 \pm 0.02, \mathrm{n}=9), \mathrm{OOD}=0.24-0.28(0.27 \pm 0.01), \mathrm{OCD}= \\
& 0.16-0.19(0.18 \pm 0.02, \mathrm{n}=7), \mathrm{UOD}=0.84-0.90(0.87 \pm 0.03), \mathrm{MOD}=0.92-1.03(0.97 \pm 0.04), \mathrm{LOD}= \\
& 0.55-0.61(0.59 \pm 0.02), \mathrm{IAD}=0.23-0.26(0.24 \pm 0.01), \mathrm{AOD}=0.16-0.19(0.17 \pm 0.01), \mathrm{CAL}=0.19- \\
& 0.28(0.25 \pm 0.02), \mathrm{CPL}=0.31-0.35(0.33 \pm 0.01), \mathrm{EL}=0.95-1.05(1.00 \pm 0.04), \mathrm{EW}=0.45-0.50(0.47 \\
& \pm 0.02), \mathrm{GW}=0.20-0.35(0.28 \pm 0.04), \mathrm{SPL}=0.29-0.32(0.31 \pm 0.01), \mathrm{F} 1 \mathrm{~L}=0.13-0.15(0.14 \pm 0.01),
\end{aligned}
$$


$\mathrm{F} 2 \mathrm{~L}=0.23-0.27(0.24 \pm 0.01), \mathrm{F} 3 \mathrm{~L}=0.24-0.27(0.26 \pm 0.01), \mathrm{F} 2 \mathrm{~W}=0.15-0.16(0.15 \pm 0.01, \mathrm{n}=9)$, $\mathrm{MsW}=1.30-1.50(1.44 \pm 0.07), \mathrm{SCL}=0.30-0.35(0.33 \pm 0.02), \mathrm{MNL}=0.15-0.20(0.17 \pm 0.02), \mathrm{MPL}=$ $0.28-0.33(0.31 \pm 0.02), \mathrm{MtW}=1.00-1.18(1.07 \pm 0.06)$.
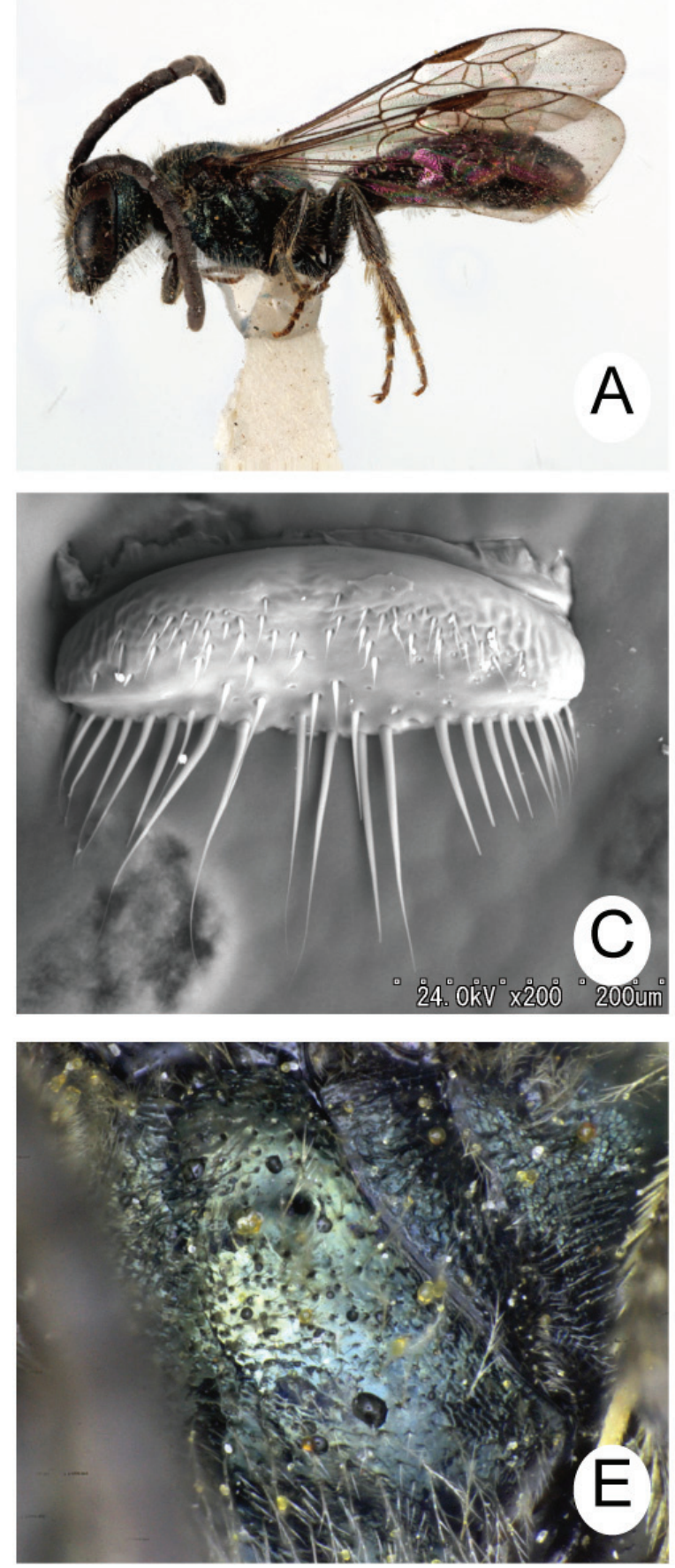
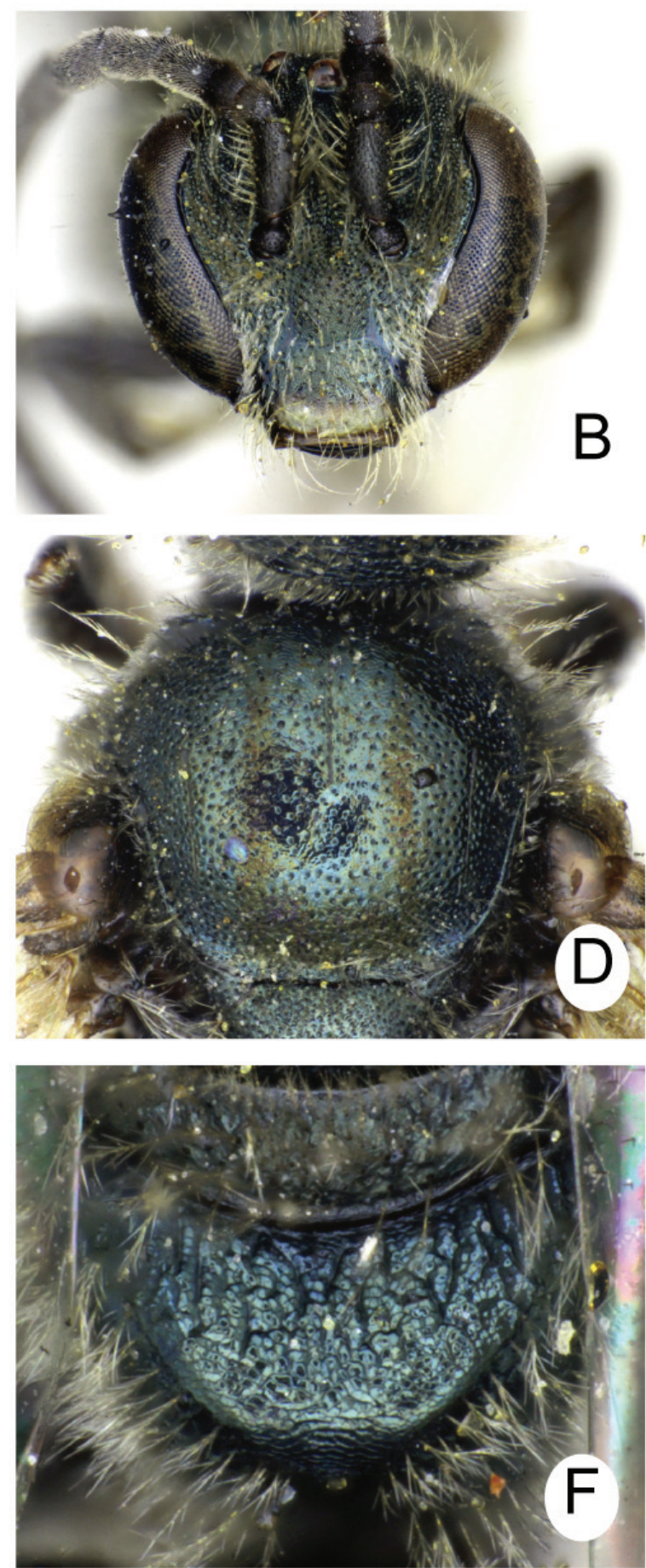

Fig. 10. Lasioglossum (Dialictus) taiwanense Murao sp. nov., §ิ. A. Lateral habitus. B. Head in frontal view. C. Labrum. D. Mesoscutum. E. Mesepisternum. F. Metapostnotum. A-B, E-F. Holotype. C-D. Paratype. 
MURAO R. et al., Dialictus of Japan, the Korean Peninsula, and Taiwan

\section{Description}

Male

Coloration. Body black except for the following parts: head dark green and mesosoma metallic green; clypeus yellow on lower half or lower 1/3; mandible reddish brown apically; flagellum blackish brown or brown ventrally; tegula blackish brown translucent; tibial spur yellow; metasomal terga narrowly brown translucent apically. Wings transparent, veins and stigma brown.

PuBESCENCE. Body hairs whitish, and covered with erect and sparse fine, branched hairs except for the following parts: lower clypeus with sparse simple hairs; tibial and tarsal hairs nearly simple; disc of metasomal terga with sparse and simple short hairs. Metasomal sterna with sparse and short hairs, without special hair tufts.

HEAD. Wider than long; HW:HL $=1: 0.96$. Vertex rounded in frontal view. MOD:UOD:LOD $=$ 1:0.90:0.61. IOD:OOD:OCD = 1:1.11:0.76. IAD:AOD = 1:0.71. Ocellocular areas, paraocular areas and frons dull, with reticulate PP. Supraclypeal area weakly convex, dull, with moderately dense PP,
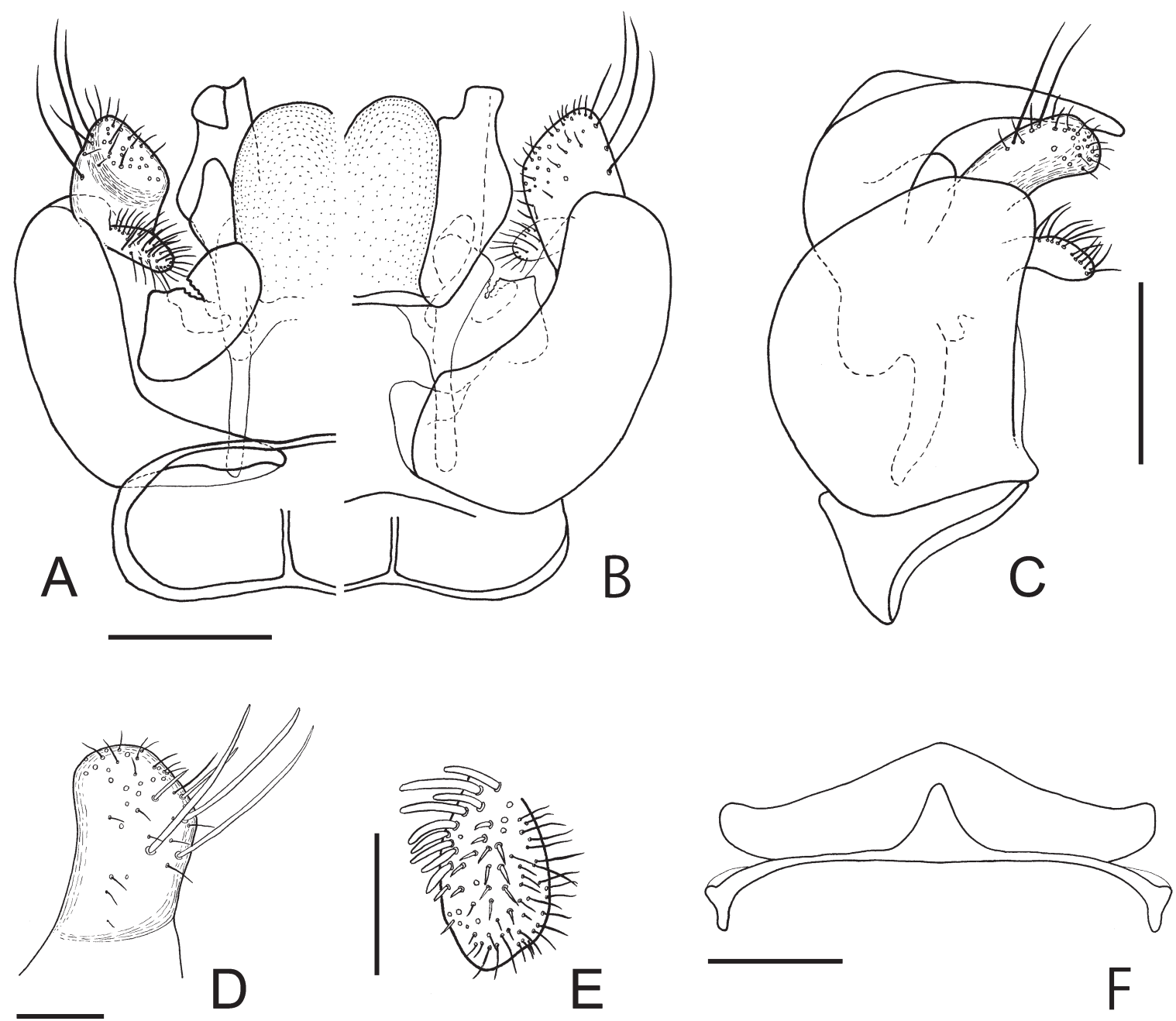

F

Fig. 11. Lasioglossum (Dialictus) taiwanense Murao sp. nov., paratype, $\hat{\partial}$. A. Genitalia in ventral view. B. Genitalia in dorsal view. C. Genitalia in lateral view. D. Gonostylus in dorsal view. E. Ventral retrorse lobe of genitalia. F. S7-S8. Scale bars: A-C, F $=0.2 \mathrm{~mm}, \mathrm{D}-\mathrm{E}=0.1 \mathrm{~mm}$. 
IS distinctly tessellate (IS $=0.5-2$ ). CPL:CAL $=1: 0.77$. Clypeus nearly flat, its sculptures similar to supraclypeal area, IS $=1-3.5 . \mathrm{EW}: \mathrm{GW}=1: 0.59$. Genal area with straight ridges and distinct tessellation. Malar space linear. Occiput not carinate. Postgena weakly tessellate. Mandible edentate. Labrum (Fig. 10C) without basal elevation and distal process. Antenna long, reaching metasoma. F2L:F2W = 1:0.63; flagellum nearly flattened on lower side.

THORAX. Dorsolateral angle of pronotum obtuse; lateral surface without ridges; lateral lobe rounded. Mesoscutum (Fig. 10D) with dense PP on marginal area, gradually sparse anterior to medial areas; IS weakly tessellate (IS $=0.5-1.5$ on marginal area, IS $=0.5-3.7$ on anterior to medial areas); parapsidal line a narrow groove. Mesoscutellum with dense PP (IS $=0.5-1.5$ ) over entire surface, IS smooth. Metanotum weakly rugulose. Mesepisternum (Fig. 10E) with sparse PP over entire surface, IS smooth (IS = 1-6). SCL:MNL:MPL = 1:0.53:0.95. Propodeum: metapostnotum (Fig. 10F) gently inclined, with longitudinal ridges on basal half, with distinct tessellation on apical half; the junction between metapostnotum and posterior surface weakly tessellate, not carinate; lateral surface weakly rugulose and distinctly tessellate; posterior surface with lateral carina on lower half. Fore trochanter narrow, longer than wide. Hind tibia without basitibial plate. Hind basitarsus slender, approximately $4.7 \times$ as long as wide. Inner hind tibial spur finely serrate.

AbDomen. Discs of T1-T3 with sparse fine PP. T1 smooth except for punctures. T2 basally and apically lineolate, T3-T5 over entire surface. S4 and S6 normal shaped, not modified. S5 gently incurved apically (Fig. 5N). S7-S8 (Fig. 11F): S7 with triangular median process, apex not exceeding S8; S8 medially weakly projecting, but not forming median process.

Genitalia (Fig. 11A-E). Gonobase short, flat at bottom, ventral arms connected with each other at upper ends; gonocoxite smooth, gently sloped in lateral view, and inner dorsal margin angulate approximately at basal 1/3; gonostylus small, truncated apically in lateral view, located on top of gonocoxite, and with sparse short and a few long hairs; ventral retrorse lobe leaf-shaped, short, with moderately dense short setae ventrally; penis valve with low cleft on top.

\section{Female}

Unknown.

\section{Variation}

The postgena nearly smooth in five paratypes (holotype and rest of paratypes weakly tessellate).

\section{Distribution}

Taiwan.

\section{Flight period}

Male: June to September.

\section{Flower records}

Not recorded. 
MURAO R. et al., Dialictus of Japan, the Korean Peninsula, and Taiwan

\section{The problematicum subgroup}

Lasioglossum (Dialictus) problematicum (Blüthgen, 1923)

Figs 13A, 14A-C, 15, 16, 19A, 27B

Halictus problematicus Blüthgen, 1923: 331-332 (lectotype: Institute of Systematic and Experimental Zoology, Polish Academy of Sciences, Krakow, Poland, + ; type locality: unknown (Siberia?); designated by Pesenko, 2007b: 115).

Halictus problematicus - Hirashima 1957: 15.

Lasioglossum (Evylaeus) problematicum - Ebmer 1978: 311-312. - Ebmer 1996: 282; Ebmer 2002: 865-867 (ठ). - Ebmer 2006: 563. — Murao et al. 2006: 50.

Evylaeus (Glauchalictus) problematicus - Pesenko 2007a: 26. — Pesenko 2007b: 85 (in key), 95 (in key), 115.

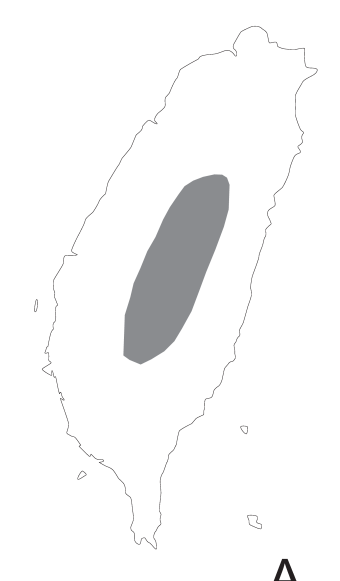

A

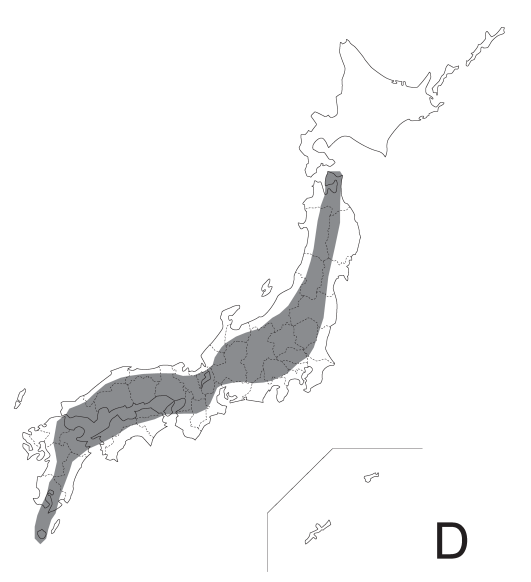

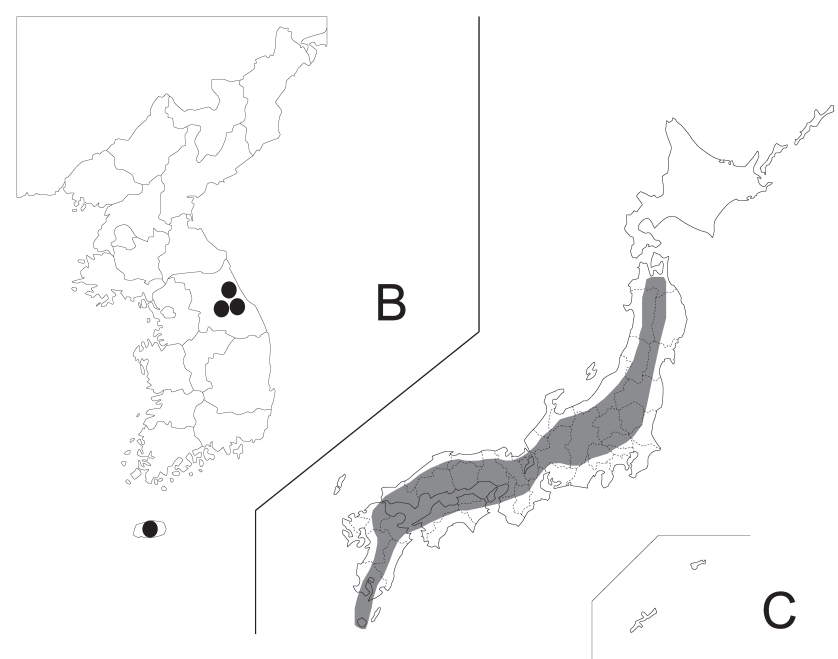

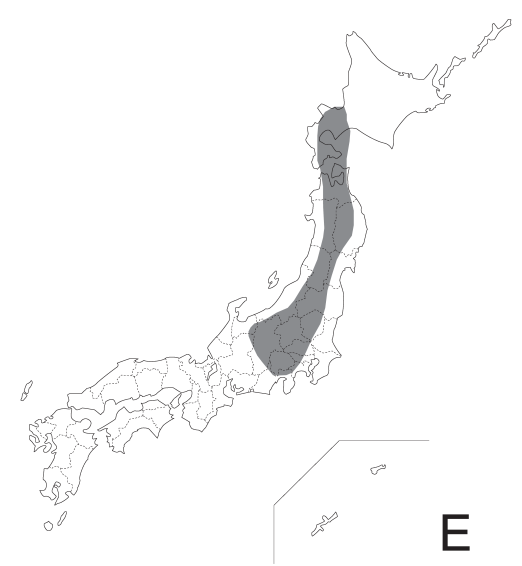

Fig. 12. Distribution maps. A. Lasioglossum (Dialictus) atroglaucum (Strand, 1913) and L. (D.) taiwanense Murao sp. nov. B-C. Lasioglossum (Dialictus) virideglaucum Ebmer \& Sakagami, 1994 (B in the Korean Peninsula, C in Japan). D. Lasioglossum (Dialictus) yamanei Murao et al., 2006. E. Lasioglossum (Dialictus) negoroi Murao \& Tadauchi, 2008. 


\section{Diagnosis}

This species is closely related to Lasioglossum alishanense Murao sp. nov., L. sanitarium (Blüthgen, 1926) and L. sichuanense Fan \& Ebmer, 1992 from the northern Oriental Region, as stated above. For the differences between this species and L. alishanense, see the Key. It is also separated from the remaining two species by having the disc of the male S5 without an apical depression (Fig. 14B). The female cannot be clearly separated from the related species, as stated above.

\section{Material examined}

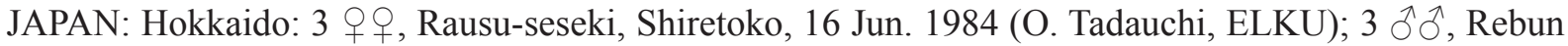

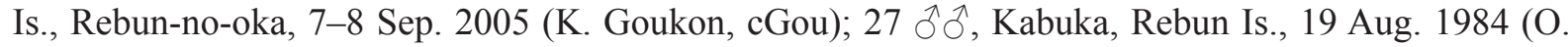

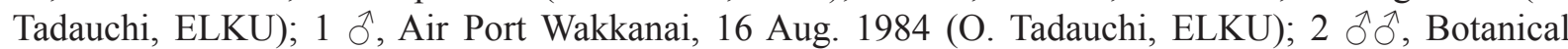
Garden, Sapporo, 3 Aug. 1959 (S. F. Sakagami \& H. Fukuda, MNHAH); 1 ð, Hamakoshimizu, 9 Aug. 1967 (MNHAN); 10 $\widehat{\jmath}$, Kami-Otoineppu, Nakagawa Exp. For., 14 Sep. 1969 (S. F. Sakagami \& H. Fukuda, MNHAH); 1 đ, Kitamoshiri, Hok. Uryu Exp. For., 14 Sep. 1969 (S. F. Sakagami \& H. Fukuda, MNHAH); 2 วิ ô, Kussharo Lake, Teshikaga, 21 Jul. 1984 (O. Tadauchi, ELKU), 30 Aug. 1984 (O. Tadauchi, ELKU); $2 \widehat{\jmath} \widehat{\partial}$, Nishiashoro, 9-10 Aug. 1955 (S. F. Sakagami \& H. Fukuda, MNHAH); $1 \widehat{\jmath}$, Nissho Pass, Hidaka, 22 Sep. 1984 (O. Tadauchi, ELKU); 1 O̊, Cape Nosappu, Nemuro, 13 Sep. 1984 (O. Tadauchi, ELKU); 1 đิ, Nukabira, 10 Aug. 1965 (Y. Hirashima, ELKU); Sapporo, 1 ô, 17 Aug. 1958, 4 ठึ ô, 8 Sep. 1958 (S. Ueda, ELKU); 1 ô, Shari Pass, Shari, 28 Jul. 1984 (O. Tadauchi, ELKU); 1 ô, Shimamaki, Shiribetsu, 2 Sep. 1984 (O. Tadauchi, ELKU); 6 ô $\widehat{\partial}$, Shotoshibetsu, 20 Jul. 1984, 9 \&
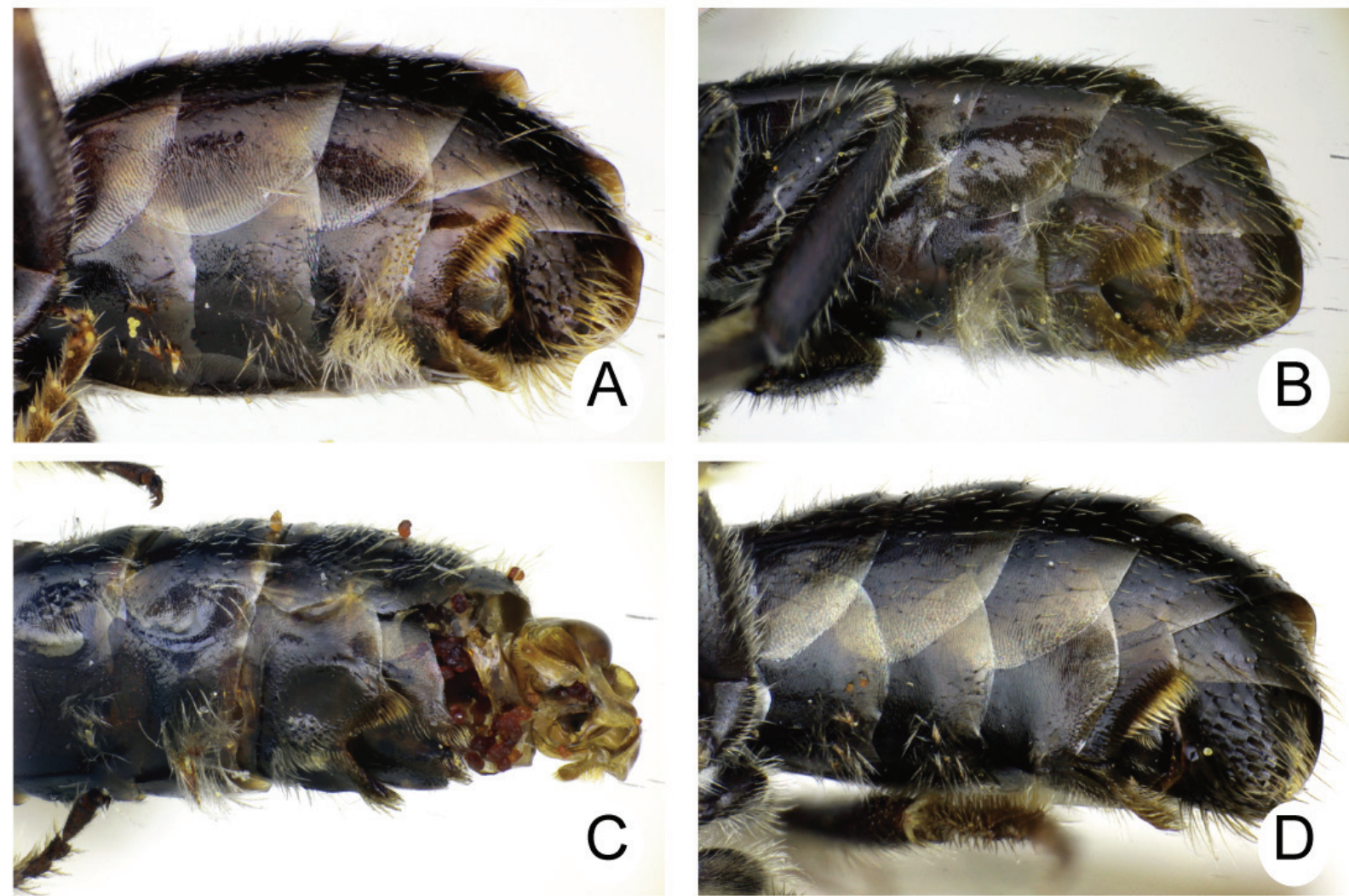

Fig. 13. Hairs on metasomal sterna in species of the problematicum subgroup, ô. A. Lasioglossum (Dialictus) problematicum (Blüthgen, 1923). B. Lasioglossum (Dialictus) sanitarium (Blüthgen, 1926). C. Lasioglossum (Dialictus) sichuanense Fan \& Ebmer, 1992. D. Lasioglossum (Dialictus) alishanense Murao sp. nov., holotype. 
MURAO R. et al., Dialictus of Japan, the Korean Peninsula, and Taiwan

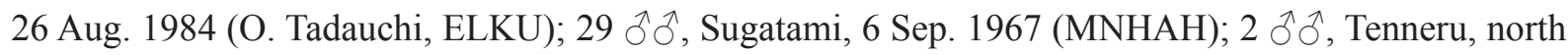
Kushiro, 1968 (E. Ohtsuka, MNHAH); 4 गेंत, Tokachimitsumata, Kamishihoro, 27 Aug. 1984, 11 Sep. 1984 (O. Tadauchi, ELKU); 6 ภ̊̉, Rubetu, Etorofu Is., 31 Aug. 1940 (S. Kuwayama \& Y. Sugihara, ELKU); 13 ô ðै, Sibetoru, Etorofu Is., 6-7 Sep. 1940 (S. Kuwayama \& Y. Sugihara, ELKU). Honshu:

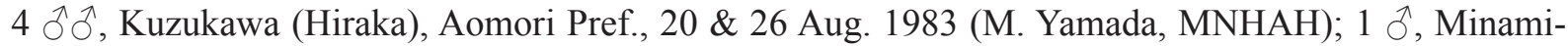
Hakkoda (Hiraka), Aomori Pref., 17 Aug. 1984 (M. Yamada, MNHAH); 6 ふð, Mt. Iwaki, Aomori

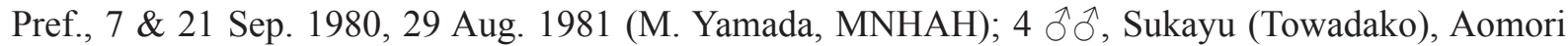
Pref., 2 Aug. 1987 (M. Yamada, MNHAH); 1 §̃, Takinosawa, Aomori Pref., 4 Sep. 1982 (M. Yamada,

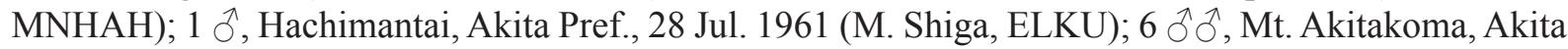
Pref., 28 Aug. 1972 (M. Honda, ELKU); 1 ô, Mt. Chôkai-san, Akita Pref., 27 Aug. 1972 (M. Honda,

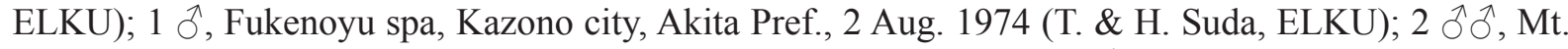
Zao, Shibakusadaira, Miyagi Pref., 27 Aug. 2004 (K. Goukon, cGou); 1 §ે, Mt. Zao, alt. 1300 m, Miyagi

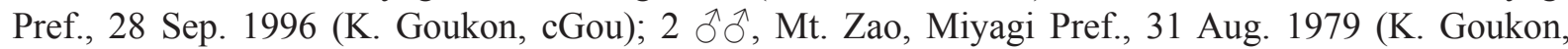
cGou), 24 Aug. 1979 (Y. Maeta, ELKU); 15 đึ ${ }^{\lambda}$, Kazawa, Nagano Pref., 17 Aug. 1972 (Y. Yoshiyasu, ELKU); $2 \partial^{\lambda}$, Shiga Highlands, Nagano Pref., 16 Aug. 1972 (Y. Yoshiyasu, ELKU); $2 \partial^{\lambda}$, Sugadaira Highlands, Sanada-machi, Nagano Pref., 22 Aug. 2002 (K. Mitai, cMur); 2 đิ ô, Asama, Karuizawa, Nagano Pref., 23 Aug. 1967 (T. \& H. Suda, ELKU); 1 ภ, Shirakaba Lake, Chino city, Nagano Pref., 7 Sep. 1966 (T. \& H. Suda, ELKU); 1 ô, Arimine, Ôyama-machi, Toyama Pref., 11 Aug. 1994 (H. Negoro,
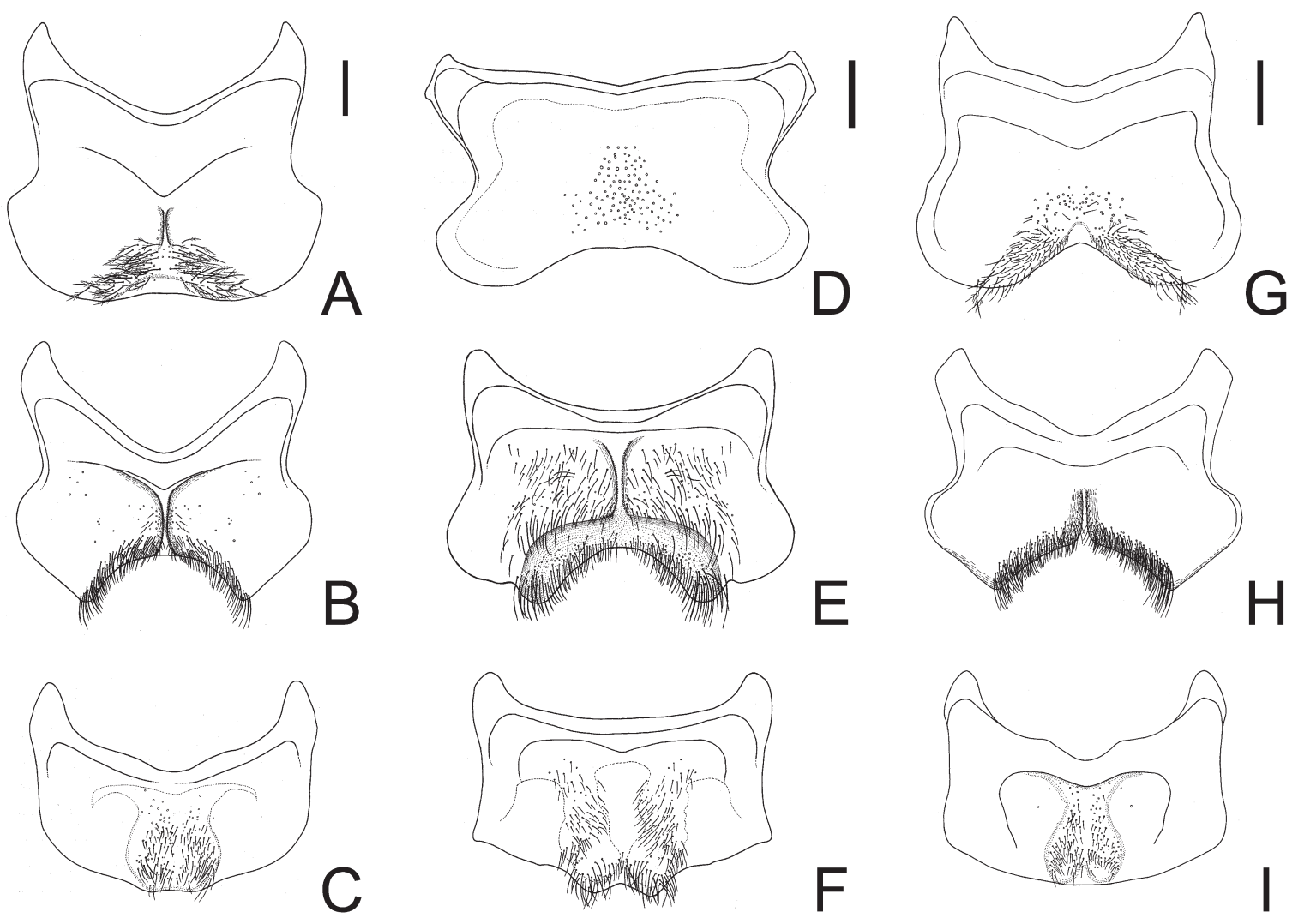

Fig. 14. S4-S6 in species of the problematicum subgroup, o. A-C. Lasioglossum (Dialictus) problematicum (Blüthgen, 1923). D-F. Lasioglossum (Dialictus) sanitarium (Blüthgen, 1926). G-I. Lasioglossum (Dialictus) alishanense Murao sp. nov., paratype. A, D, G: S4. B, E, H: S5. C, F, I. S6: Dotted area on S5 shows the apical depression. Scale bars: $0.2 \mathrm{~mm}$. 


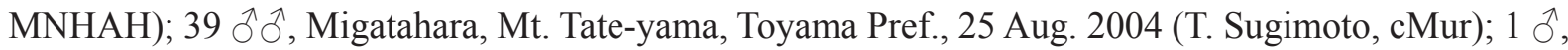
Mt. Daicho, Katsuyama-shi, Toyama Pref., 27 Aug. 2004 (T. Sugimoto, cMur); 1 गे, Sen-ninmori, near Mt. Ikenodaira, north Alps, Toyama Pref., 19 Aug. 2005 (H. Hirano, cMur); 1 đे, Tateyama-Migatahara,

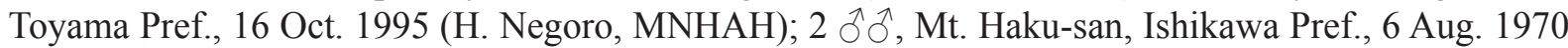
(K. Kanmiya, ELKU), 9 Aug. 1974 (I. Togashi, ELKU); 1 §, Mt. Haku-san, alt. 1750-1500 m, Ishikawa Pref., 22 Aug. 1988 (I. Togashi, ELKU).

\section{Additional description}

LABRUM (Fig. 15C-D). Basal area approximately $2.3 \times$ as wide as long in female, $3 \times$ in male; basal elevation of female moderately developed, that of male absent; distal process of female slender, nearly as long as basal area, and without lateral projection, that of male absent; keel of distal process narrow, apically pointed; labral fimbria acutely pointed at apex in both sexes.

STERNA. S4 medially with shallow groove on apical half; apical margin nearly straight. S5 without apical depression, medially weakly swollen and apico-medially cleaved; apical margin gently incurved. S6 normally shaped, not modified. S7-S8 (Fig. 16F): S7 with elongate, apically rounded median process, apex exceeding S8; S8 without median process.

Male Genitalia (Fig. 16A-E). Gonobase nearly flat at bottom, ventral arms connected with each other at upper ends; gonocoxite smooth, gently sloped in lateral view, and inner dorsal margin gently angulate
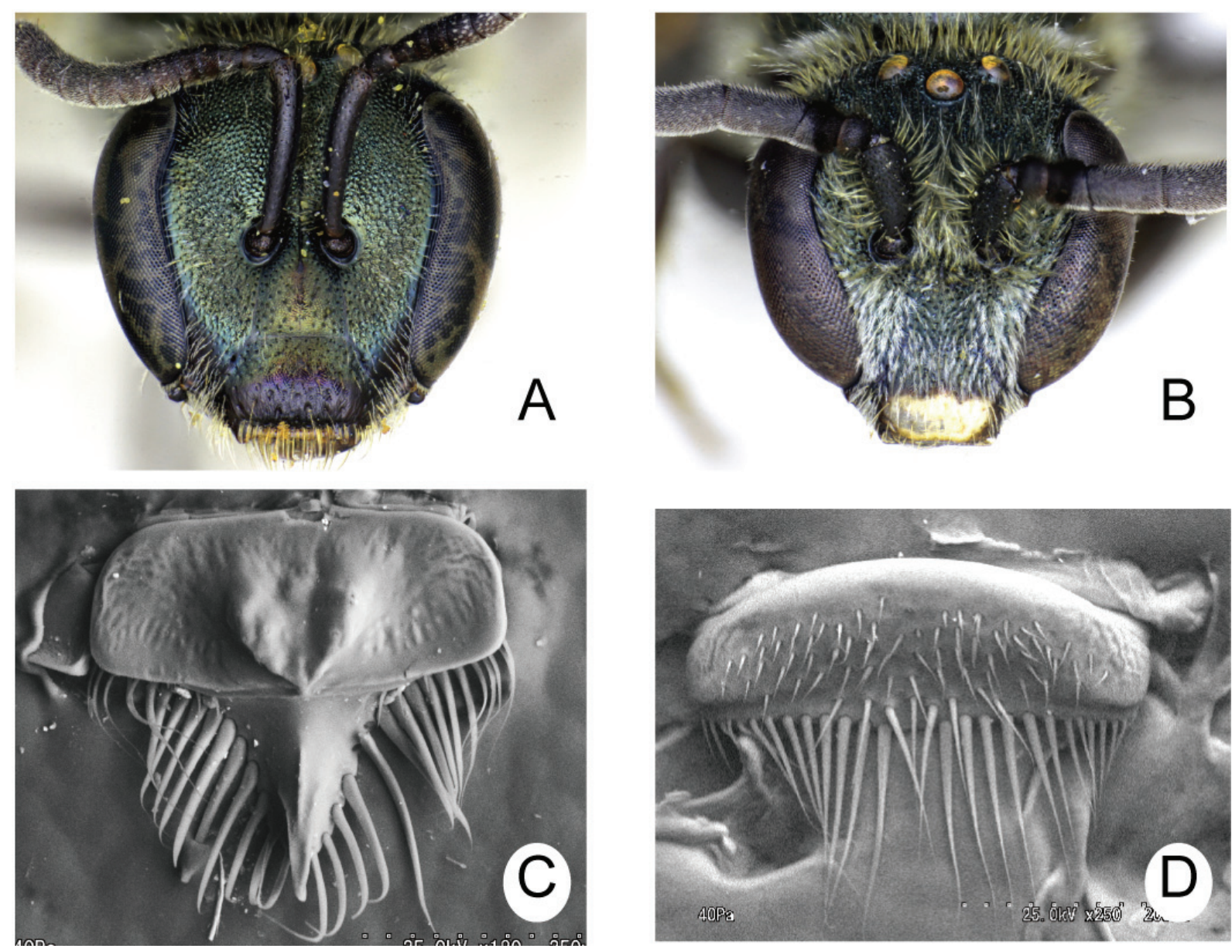

Fig. 15. Lasioglossum (Dialictus) problematicum (Blüthgen, 1923). A-B. Head. C-D. Labrum. A, C. + . B, D. $0^{\top}$. 
at approximately basal 1/3; gonostylus large, located at top of gonocoxite, with dense short setae on inner surface; ventral retrorse lobe moderately long but not reaching gonobase, with dense short setae ventrally and relatively long blunt setae laterally; penis valve higher than gonocoxite, with high cleft on top.

\section{Distribution}

Russian Far East (Sakhalin) and Japan (Hokkaido, northern to central Honshu). Ebmer $(1978,2006)$ recorded this species from Primorsky and North Korea, respectively, based on female specimens. These records are not included in this paper, because the female cannot be clearly separated from that of some of the related species.
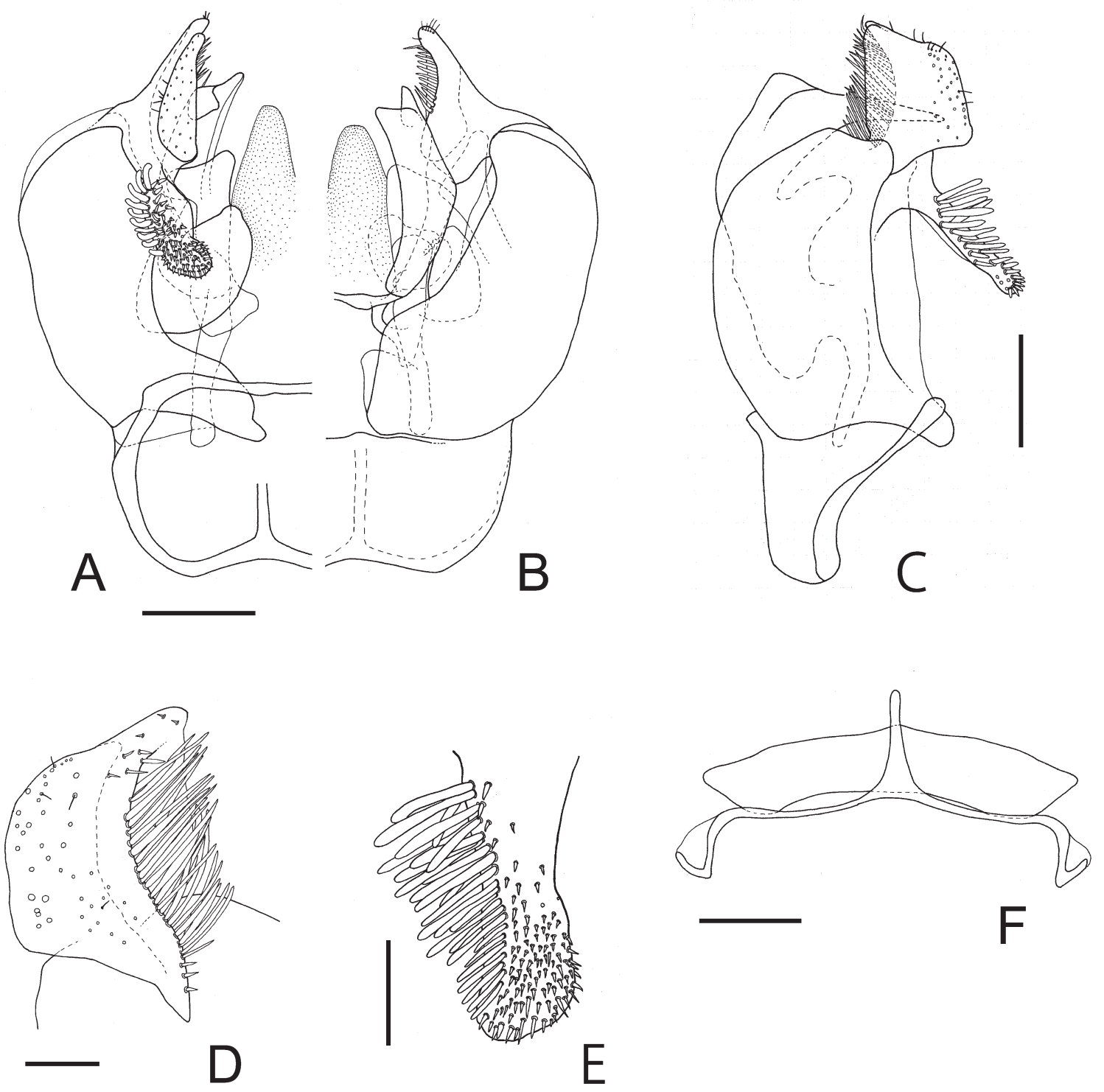

Fig. 16. Lasioglossum (Dialictus) problematicum (Blüthgen, 1923), §̂. A. Genitalia in ventral view. B. Genitalia in dorsal view. C. Genitalia in lateral view. D. Gonostylus in inner-lateral view. E. Ventral retrorse lobe of genitalia. F. S7-S8. Scale bars: A-C, F $=0.2 \mathrm{~mm}, \mathrm{D}-\mathrm{E}=0.1 \mathrm{~mm}$. 


\title{
Flight period
}

Female: May to September in Hokkaido, Japan.

Male: August to October.

The flight record of females is based on specimens collected from the eastern part of Hokkaido, Japan. This record can be considered accurate, because one of the related species, L. virideglaucum Ebmer \& Sakagami, does not sympatrically inhabit this area.

\section{Flower records}

In Japan this species visits the following 19 species in 6 families: Apiaceae: Angelica ursina (Rupr.) Maxim. Asteraceae: Anaphalis margaritacea (L.) Benth. \& Hook. f. subsp. margaritacea; Aster glehnii F. Schmidt; Cirsium setosum (Willd.) M. Bieb.; Crepidiastrum denticulatum (Houtt.) J.H. Pak \& Kawano; Erigeron annuus (L.) Pers.; Hieracium umbellatum L.; Picris hieracioides subsp. japonica (Thunb.) Krylov; Rudbeckia laciniata L.; Senecio pseudoarnica Less.; Solidago altissima L.; S. virgaurea L. subsp. asiatica (Nakai ex H. Hara) Kitam. ex H. Hara var. asiatica Nakai ex H. Hara; S. virgaulea L. subsp. leiocarpa (Benth.) Hultén; Sonchus brachyotus DC.; Taraxacum sp. Brassicaceae: Barbarea orthoceras Ledeb. Geraniaceae: Geranium thunbergii Siebold ex Lindl. \& Paxton. Lamiaceae: Isodon sp. Rosaceae: Sorbaria sorbifolia (L.) A. Braun.

\section{Biological reference}

According to Sakagami \& Kuribayashi (1979) and Sakagami et al. (1984), some biological information is available. Nest place and structure: the female prefers to make a nest at the forest edge; the nest structure is the IIIa type of Sakagami \& Michener (1962). Social structure and life cycle: the brooding period of the overwintered generation is from early May to late July, in Sapporo city, Hokkaido; most of the overwintering females stay communally in the natal nests; the nest are communally reused in the next brooding season, hence many colonies are semisocial or sometimes delayed eusocial from the beginning of spring activities; females living in the same nests are mostly of the same generation and seem to be sisters in most cases, although some nests are inhabited by a two-year-old female and her daughters; all cohabiting females are inseminated, but only one of them has fully developed ovaries at the peak of brooding season, the others with undeveloped ovaries participate in foraging.

Lasioglossum (Dialictus) alishanense Murao sp. nov. urn:1sid:zoobank.org:act:34A726F0-E3B3-4E3F-B6B8-111E08F19BD2

Figs. 13D, 14G-I, 17, 18, 19B

\section{Diagnosis}

This species may be closely related to Lasioglossum problematicum, L. sanitarium, and L. sichuanense, as stated above. For the differences between this species and L. problematicum, see the Key. It is separated from the two other related species by the disc of the male S4 having short and sparse hairs (Fig. 13D), the male S5 without an apical depression (Fig. 14H), and the shape of gonostylus of male genitalia (Fig. 18C).

\section{Etymology}

The specific name is derived from the type locality, Mt. Alishan in Taiwan.

\author{
Material examined \\ Holotype \\ TAIWAN: $\widehat{\jmath}$, Chiayi-Hsien Alishan, 27 Jul. 1966 (T. Tano, ELKU).
}


MURAO R. et al., Dialictus of Japan, the Korean Peninsula, and Taiwan

\section{Paratypes}

TAIWAN: 1 Ô, Taiheizan (Taihoku-shû), Toganoo-Minamotojobu-Kussha, 22 Jul. 1932 (T. Esaki, ELKU); 1 ô, Chiayi-Hsien Shihtzulu, 29 Jul. 1966 (T. Tano, ELKU); 3 $\widehat{\partial}$, Chiayi-Hsien Alishan, 27 Jul. 1966 (T. Tano, ELKU); 1 ðै, Fenchifu, alt. 1405 m, 1 Sep. 1979 (Y. Hirashima, ELKU).

Measurements $(\mathrm{n}=6$, unit $\mathrm{mm})$

$\mathrm{BL}=5.86-6.86(6.38 \pm 0.43), \mathrm{WL}=5.43-6.00(5.79 \pm 0.22), \mathrm{HL}=1.39-1.58(1.51 \pm 0.07), \mathrm{HW}=1.42-$ $1.58(1.52 \pm 0.06), \mathrm{IOD}=0.23-0.24(0.23 \pm 0.01), \mathrm{OOD}=0.27-0.35(0.31 \pm 0.03), \mathrm{OCD}=0.23-0.24$ $(0.24 \pm 0.01), \mathrm{UOD}=0.90-1.03(0.98 \pm 0.05), \mathrm{MOD}=1.02-1.13(1.08 \pm 0.05), \mathrm{LOD}=0.61-0.74(0.69$ $\pm 0.05), \mathrm{IAD}=0.24-0.31(0.27 \pm 0.03), \mathrm{AOD}=0.16-0.21(0.19 \pm 0.02), \mathrm{CAL}=0.24-0.27(0.25 \pm 0.01)$, $\mathrm{CPL}=0.35-0.39(0.37 \pm 0.02), \mathrm{EL}=0.98-1.10(1.03 \pm 0.05), \mathrm{EW}=0.50-0.53(0.50 \pm 0.01), \mathrm{GW}=$ $0.28-0.35(0.33 \pm 0.03), \mathrm{SPL}=0.32-0.39(0.36 \pm 0.02), \mathrm{F} 1 \mathrm{~L}=0.15-0.16(0.15 \pm 0.01), \mathrm{F} 2 \mathrm{~L}=0.27-0.29$ $(0.28 \pm 0.01), \mathrm{F} 3 \mathrm{~L}=0.29-0.32(0.30 \pm 0.01), \mathrm{F} 2 \mathrm{~W}=0.16-0.18(0.16 \pm 0.01), \mathrm{MsW}=1.55-1.70(1.60$ $\pm 0.06), \mathrm{SCL}=0.35(0.35 \pm 0.00), \mathrm{MNL}=0.18-0.20(0.19 \pm 0.01), \mathrm{MPL}=0.31-0.38(0.34 \pm 0.03), \mathrm{MtW}$ $=1.15-1.40(1.29 \pm 0.09)$.

\section{Description}

\section{Male}

Coloration. Body black, except for the following parts: head dark green and mesosoma metallic green; clypeus yellow on lower half; mandible reddish brown apically; flagellum blackish brown ventrally; tegula dark brownish translucent; tibial spur yellow; metasomal terga narrowly dark brownish translucent apically. Wings transparent, veins and stigma brown.

PubesCence. Body hairs whitish, and covered with elect and sparse fine, branched hairs except for the following parts: lower paraocular area with sparse tomentose; lower clypeus with sparse simple hairs; tibial and tarsal hairs nearly simple; disc of metasomal terga with sparse and simple short hairs. S2-S4 medioapically with sparse erect hairs; in addition, S4 lateroapically with sparse short hairs. S5 with dense, brush-like, and brownish hairs along apical margin.

HEAD. As long as wide; $\mathrm{HW}: \mathrm{HL}=1: 0.99$. Vertex rounded in frontal view. MOD:UOD:LOD = 1:0.90:0.64. IOD:OOD:OCD = 1:1.33:1.01. IAD:AOD = 1:0.70. Ocellocular areas, paraocular areas and frons dull, with reticulate PP. Supraclypeal area weakly convex, dull, with sparse PP, IS distinctly tessellate (IS = $0.5-3)$. CPL:CAL $=1: 0.68$. Clypeus nearly flat, its sculptures similar to supraclypeal area, IS $=1-4$. $\mathrm{EW}: \mathrm{GW}=1: 0.64$. Malar space linear. Occiput not carinte. Postgena nearly smooth. Mandible edentate. Labrum (Fig. 17C) without basal elevation and distal process. Antenna long, reaching metasoma. $\mathrm{F} 2 \mathrm{~L}: \mathrm{F} 2 \mathrm{~W}=1: 0.57$; flagellum nearly flattened ventrally.

THORAX. Dorsolateral angle of pronotum obtuse; lateral surface without ridges; lateral lobe rounded. Mesoscutum (Fig. 17D) with dense PP on marginal area, gradually sparse toward anterior to medial areas; IS weakly tessellate (IS $=0.5-1.5$ on marginal area, $0.5-2.5$ on anterior to medial area); parapsidal line a narrow groove. Mesoscutellum with dense PP over entire surface, IS smooth (IS = 1-2). Metanotum distinctly tessellate, not coarsely rugulose. Mesepisternum (Fig. 17E) with sparse PP over entire surface, IS smooth (IS=1-6.5). SCL:MNL:MPL = 1:0.54:0.98. Propodeum: metapostnotum (Fig. 17F) gently inclined, with nearly longitudinal ridges not attaining posterior margin; junction between propodeal dorsum and shield smooth, not carinate; lateral surface weakly rugulose and distinctly tessellate; posterior surface weakly tessellate, with lateral carina on lower $1 / 3$ and without oblique carina. Fore trochanter narrow, longer than wide. Hind tibia without basitibial plate. Hind basitarsus slender, approximately $4 \times$ as long as wide. Inner hind tibial spur finely serrate. Fore wing with three submarginal cells. 
ABdomen. Discs of T1-T3 with sparse fine PP. T1-T2 smooth except for punctures. T3-T5 with weak lineolation over entire surface. Apical margin of S4-S5 incurved (Fig. 14G, H); shape of S5 as in $L$. problematicum. S6 normally shaped, not modified. S7-S8 (Fig. 18E): S7 with narrow median process, apex as high as top of S8; S8 without median process.
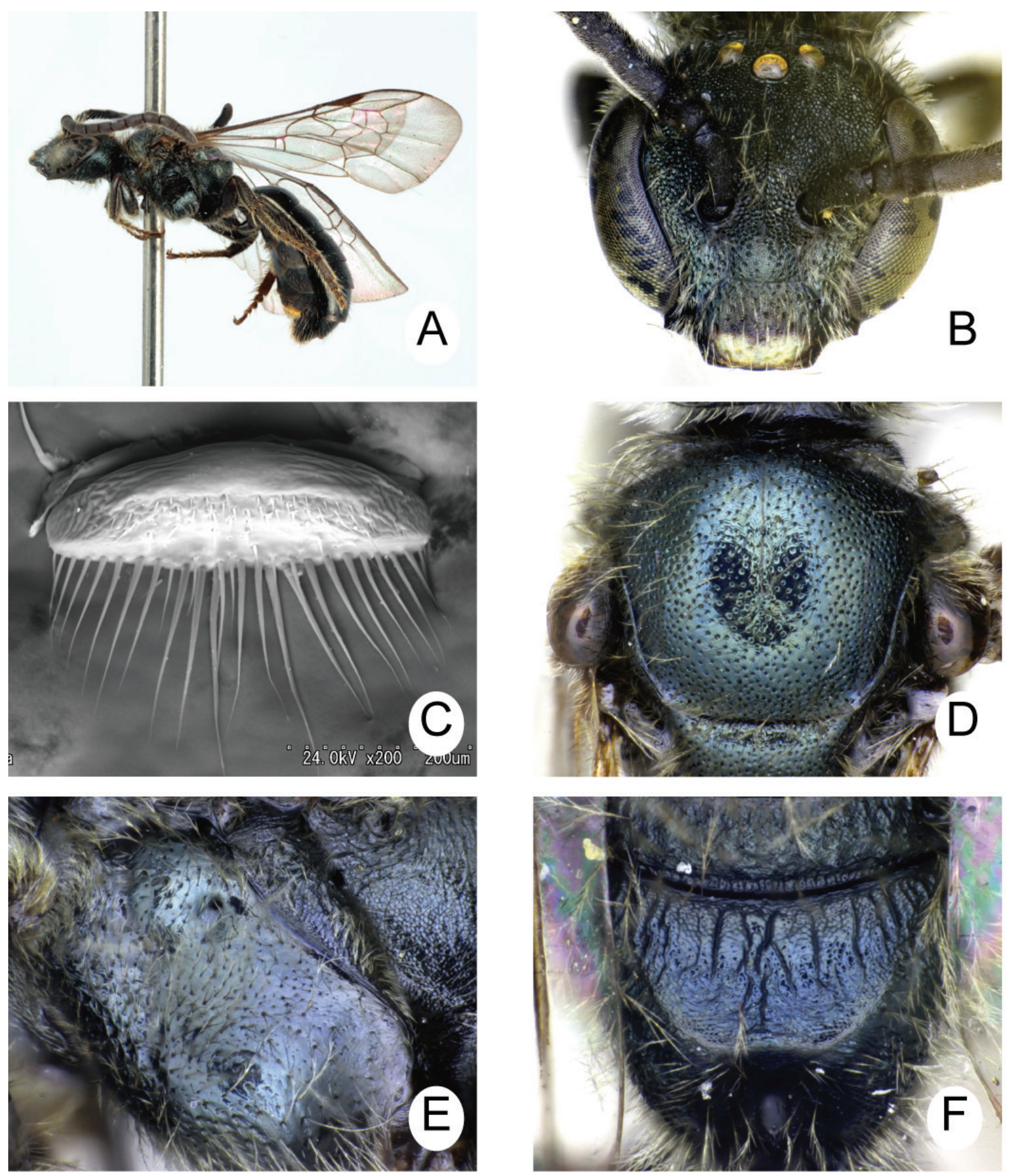

Fig. 17. Lasioglossum (Dialictus) alishanense Murao sp. nov., ô. A. Lateral habitus. B. Head in frontal view. C. Labrum. D. Mesoscutum. E. Mesepisternum. F. Metapostnotum. A-B, E-F. Holotype. C-D. Paratype. 
Genitalia (Fig. 18A-D). Gonobase flat at bottom, ventral arms not connected with each other at upper ends; gonocoxite smooth, gently sloped in lateral view, and inner dorsal margin gently angulate approximately at basal $1 / 3$; gonostylus large, similar to that of $L$. problematicum in shape, located on top of gonocoxite, and with dense setae on inner surface; ventral retrorse lobe tongue-like, moderately long but not reaching gonobase, with dense short setae ventrally and relatively long blunt setae laterally; penis valve with high cleft on top.

\section{Female}

\section{Unknown.}

\section{Distribution}

Taiwan.

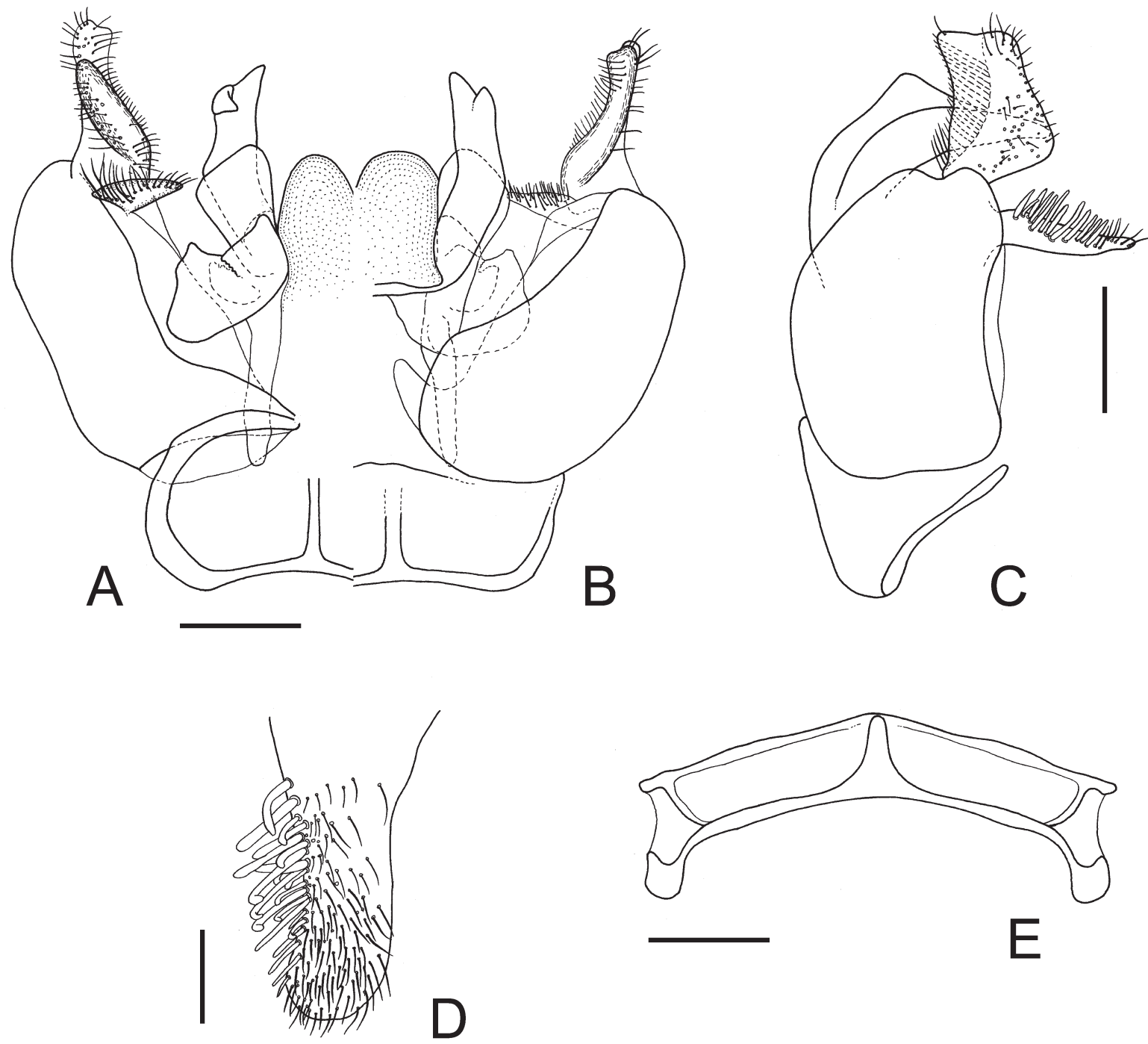

Fig. 18. Lasioglossum (Dialictus) alishanense Murao sp. nov., paratype, $\widehat{\jmath}$. A. Genitalia in ventral view. B. Genitalia in dorsal view. C. Genitalia in lateral view. D. Ventral retrorse lobe of genitalia. E. S7-S8. Scale bars: A-C, E $=0.2 \mathrm{~mm}, \mathrm{D}=0.1 \mathrm{~mm}$. 


\section{Flight period}

Male: late July to September.

\section{Flower record}

Not recorded.

\section{The morio group}

Species included in eastern Asia:

L. briseis Ebmer, 2005

L. circe Ebmer, 1982

L. ellipticeps (Blüthgen, 1923)

L. eomontanus Ebmer, 2006

L. lambatum Fan \& Ebmer, 1992

L. moros Ebmer, 2002

L. spinosum Ebmer, 1982

Only one species, listed below, is known to occur on the Korean Peninsula.

\section{Diagnosis and comments}

This group in the present paper corresponds to Evylaeus (Smeathhalictus) Warncke sensu Pesenko (2007a). According to Pesenko's key (2007a), this group is separated from the other Palaearctic groups by a combination of the following character states: 1 ) body small, body length $=4.0-6.5 \mathrm{~mm}$ in both sexes, 2) head usually longer than wide in both sexes, 3) male antenna long, reaching propodeum, 4)
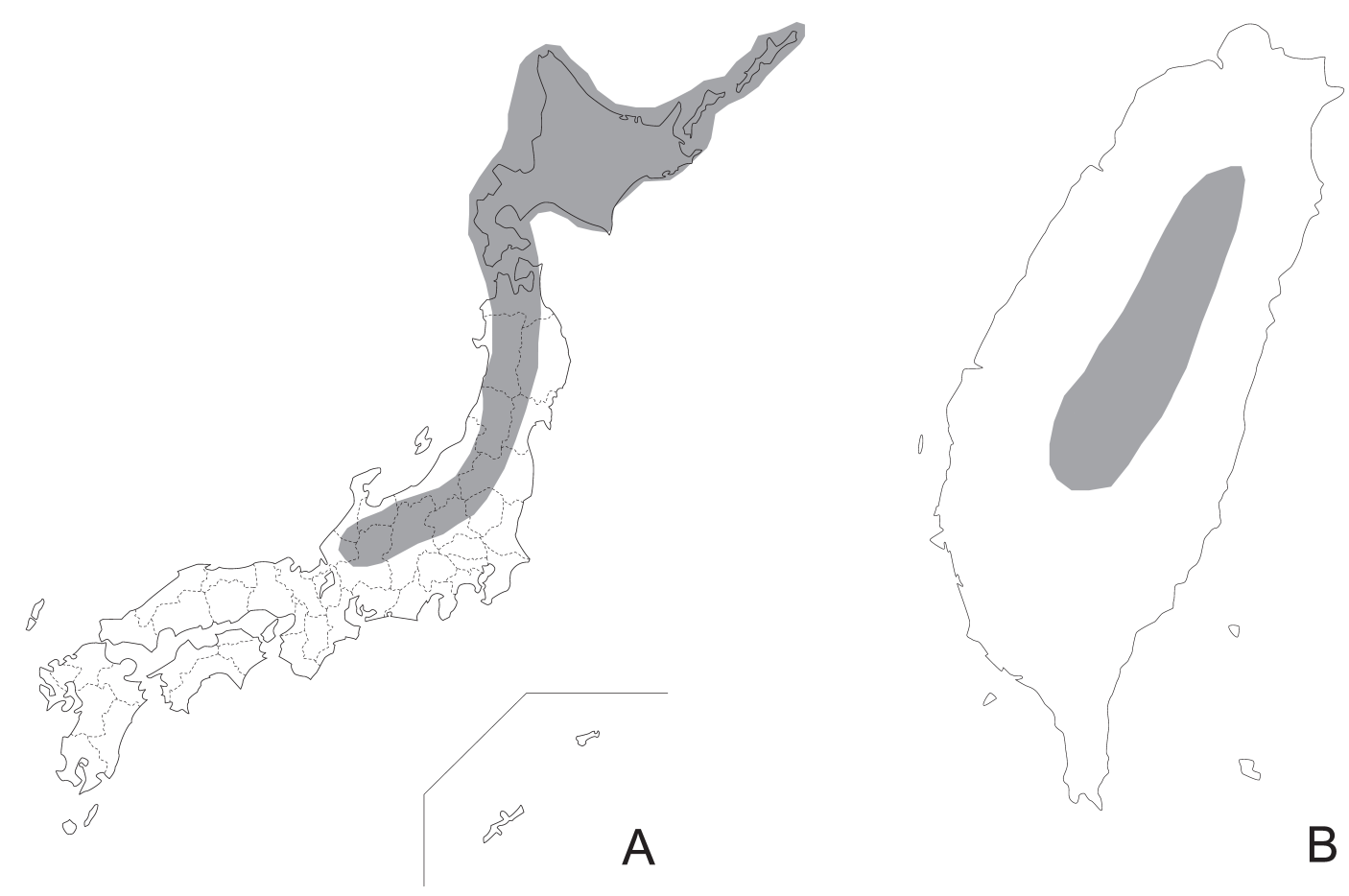

B

Fig. 19. Distribution maps. A. Lasioglossum (Dialictus) problematicum (Blüthgen, 1923) in Japan. B. Lasioglossum (Dialictus) alishanense Murao sp. nov. 
MURAO R. et al., Dialictus of Japan, the Korean Peninsula, and Taiwan

male F2 $1.5-1.7 \times$ as long as its diameter, 5) female mesocutum and mesopleuron punctate, 6) length of metapostnotum as long as or longer than mesoscutellum in both sexes, 7) female metapostnotum striate, more or less shiny, 8) posterior surface of propodeum usually with complete lateral carina in both sexes, 9) male metasoma elongate, 10) female T1 apically with fine lineolate or shagreened, 11) T2-T4 with apical fimbriae or developed lateral spots in both sexes, 12) male metasomal sterna not modified, 13) gonostylus of male genitalia small, rounded triangular, trapeziform or elongate elliptical, and not narrowed at base and 14) ventral retrorse lobe of male genitalia rounded, elliptical, sometimes triangular. However, it is very difficult or impossible to separate from all other group based on these character states. This group needs a revision of the diagnostic characters through detailed morphological and phylogenetic studies.

\section{Distribution}

Palaearctic to northern Oriental Region. It is diverse in the western Palaearctic Region.

Lasioglossum (Dialictus) ellipticeps (Blüthgen, 1923)

Figs 20, 21, 22A, 26B

Halictus ellipticeps Blüthgen, 1923: 254 (holotype: Museum für Naturkunde, Humboldt Universität zu Berlin, Germany, 9 ; type locality: Amur, Russia).

Halictus permicus Blüthgen, 1923: 330-331 (lectotype: Institute of Systematic and Experimental Zoology, Polish Academy of Sciences, Krakow, Poland, ô’; type locality: "Perm", designated by Pesenko, 2007b: 117). Synonymized by Ebmer, 1978.

Halictus (Chloralictus) mayacensis Cockerell, 1924: 582 (syntypes: U. S. National Museum of Natural History, Smithsonian Institution, Washington, DC, USA, o ; type locality: Primorsky, Russia); Synonymy by Blüthgen 1931.

Halictus ellipticeps - Hirashima 1957: 7-8.

Lasioglossum (Evylaeus) ellipticeps Ebmer 1978: 310-311. — Ebmer 1982: 215-216. — Ebmer 1996: 282-283. - Ebmer 2005: 375. - Ebmer 2006: 565.

Evylaeus (Smeathhalictus) ellipticeps Pesenko 2007a: 28. — Pesenko 2007b: 117.

\section{Diagnosis}

This species is similar to Lasioglossum briseis Ebmer and L. eomontanus Ebmer from Far East Asia (Pesenko 2007b). For the differences between these species, see Pesenko (2007b).

\section{Material examined}

SOUTH KOREA: Gangwon-do: 2 우, Doam Myon Pyongchang-gun, 20 Aug. 2001 (Y. Maeta, SULE); 1 , , Mt. Hambaek-san, 14 Aug. 1999 (S. Park, SNU). Jeollabuk-do: JeongLyongChy, SanNaeMeon, NamWeon-gun, 14 우, 14 May 1991 (O. Tadauchi, ELKU), 1 ㅇ, 14 Jul. 1991 (K. Kanmiya, ELKU).

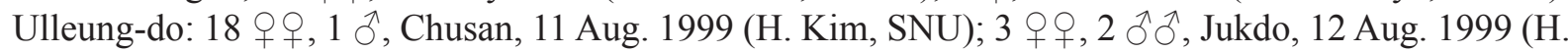
Kim, SNU); 2 우, Naesujeon, 12 Aug. 1999 (H. Kim, SNU); 1 ㅇ, 2 ภิ ô, Naribunji, 11 Aug. 1999 (H. Kim, SNU); 2 ơ ô, Seoginbong, Dodong, 10 Aug. 1999 (H. Kim, SNU). Gyeongsangnam-do: 1 ô, SamJeong Ri, 14 Jul. 1991 (K. Kanmiya, ELKU). Jeollanam-do: 3 우, Jongseokdae, Mt. Jiri-san, 29 Jul. 1999 (H. Kim, SNU); 1 ㅇ, 1 ð, Nogodan, Mt. Jiri-san, Gurye-gun, 29 Jul. 1999 (H. Kim, SNU). Jejudo: Yonsil, Mt Halla-san, 50 우, 24 Jul. 1990 (O. Tadauchi, ELKU), 12 우, 2 ふぇં, 27 Jul. 1990 (O. Tadauchi, ELKU); 13 우, 3 के ô, Mt Halla-san, alt. 1400-1600 m, 25 Jul. 1990 (O. Tadauchi, ELKU); 1 †, Ryuzinkaku, alt. 1600 m, Mt. Hanna, 16 Jul. 1968 (T. Shirozu, ELKU). 


\section{Additional description}

LABRum (Fig. 20C-D). Basal area approximately $2.2 \times$ as wide as long in female; basal elevation moderately developed in female, absent in male; distal process of female slender, nearly as long as basal
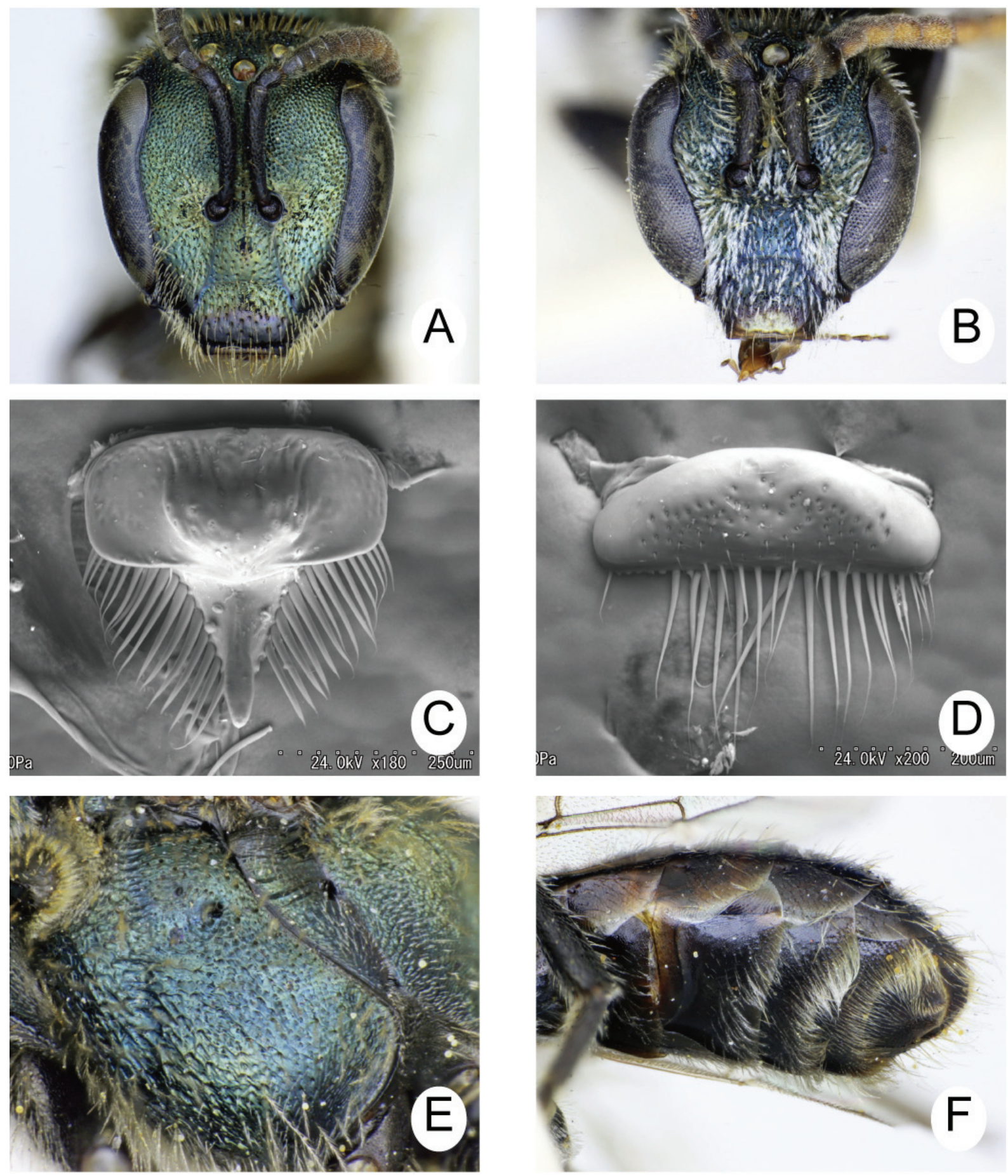

Fig. 20. Lasioglossum (Dialictus) ellipticeps (Blüthgen, 1923). A-B. Head. C-D. Labrum. E. Mesepisternum. F. Hairs on metasomal sterna. A, C, E: ㅇ. . B, D, F: $\overbrace{}^{\text {. }}$. 
MURAO R. et al., Dialictus of Japan, the Korean Peninsula, and Taiwan

area, and without lateral projection, that of male absent; keel of distal process narrow, apically bluntly pointed; labral fimbria acutely pointed at apex in both sexes.

STERNA. S7-S8 (Fig. 21E): S7 with short, apically rounded median process; median process of S8 slightly present, round or truncate apically, with sparse short hairs.

Male Genitalia (Fig. 21A-D). Gonobase nearly flat at bottom, ventral arms connected with each other at upper ends; gonocoxite smooth, gently sloping in lateral view, inner and outer dorsal margins nearly parallel; gonostylus small, bud-like in lateral view, located at top of gonocoxite, with sparse short hairs; ventral retrorse lobe tongue-like, long, apex reaching gonobase, with short hairs ventrally, apical hairs longer than around one; penis valve higher than gonocoxite, without cleft on top.

\section{Distribution}

Russian Far East (Yakutia, Khabarovsk and Primorsk Terr., Irkutsk Prov.), Mongolia and the Korean Peninsula (north, new record for south).

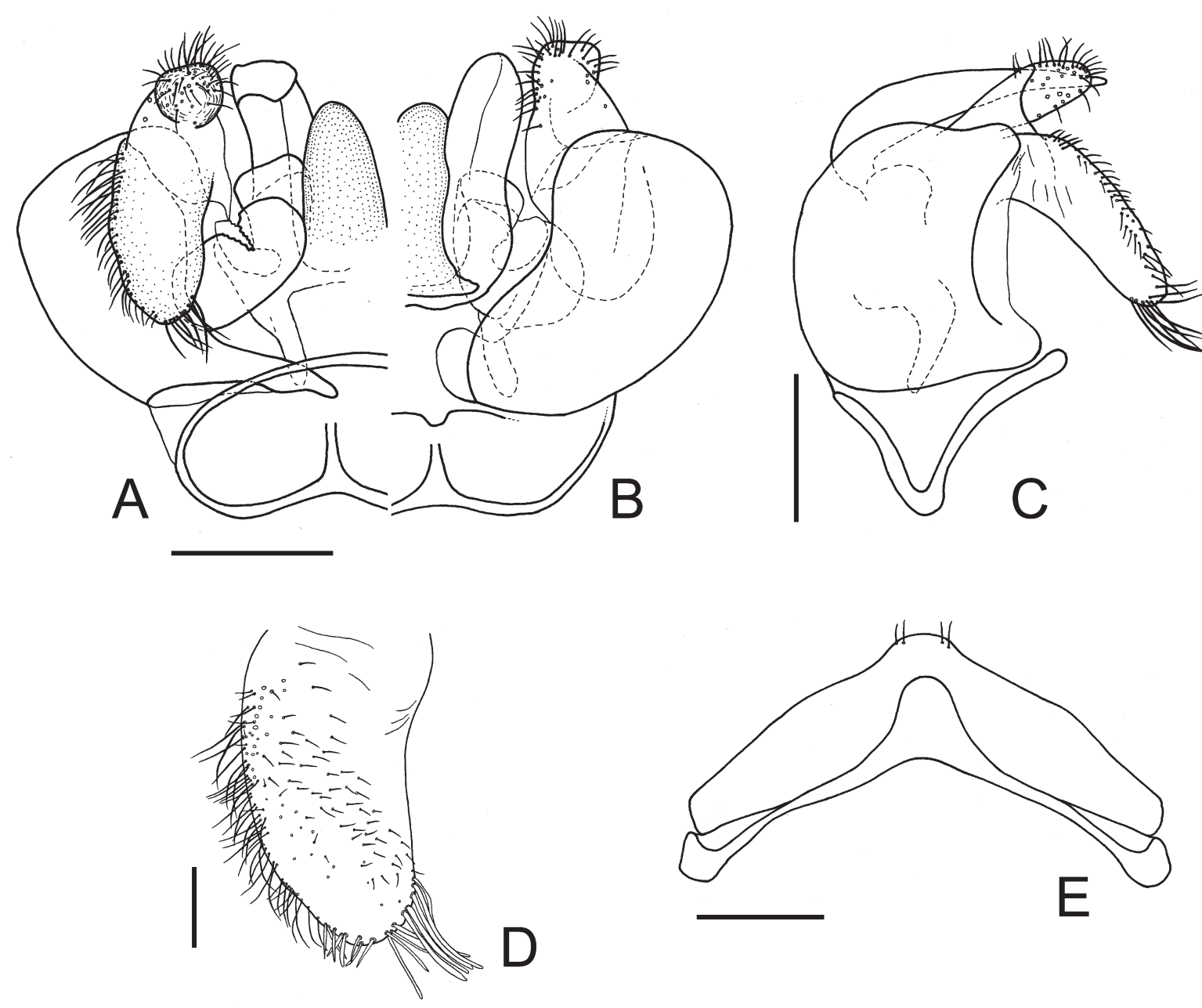

Fig. 21. Lasioglossum (Dialictus) ellipticeps (Blüthgen, 1923), §̂. A. Genitalia in ventral view. B. Genitalia in dorsal view. C. Genitalia in lateral view. D. Ventral retrorse lobe of genitalia. E. S7-S8. Scale bars: $\mathrm{A}-\mathrm{C}, \mathrm{E}=0.2 \mathrm{~mm}, \mathrm{D}=0.1 \mathrm{~mm}$. 


\section{Flight records}

Female: May to August.

Male: July.

\section{Flower records}

In South Korea, this species visits the following 10 species in 6 families. Asteraceae: Erigeron annuus (L.) Pers., Lactuca indica L. Balsaminaceae: Impatiens balsamina L., I. noli-tangere L. Campanulaceae: Campanula takeshimana Nakai, Codonopsis lanceolata (Siebold \& Zucc.) Trautv., Platycodon grandiflorus (Jacq.) A. DC. Geraniaceae: Geranium sp. Lamiaceae: Agastache rugosa (Fisch. \& C.A. Mey.) Kuntze. Lythraceae: Lythrum anceps (Koehne) Makino.

\section{Incertae sedis}

\section{Lasioglossum (Dialictus) miyabei Murao, Ebmer \& Tadauchi, 2006} Figs 22B-C, 23D, 28A

Lasioglossum (Evylaeus) miyabei Murao, Ebmer \& Tadauchi, 2006: 42-46 (holotype: ELKU, + ; type locality: Hokkaido, Japan).

Lasioglossum (Evylaeus) miyabei - Ebmer 2006: 564-565.

Evylaeus (Glauchalictus) miyabei - Pesenko 2007a: 26. — Pesenko 2007b: 85 (in key), 99 (in key), $114-115$.

\section{Diagnosis}

This species is separated from other eastern Asian species of Lasioglossum (Dialictus) by a combination of the following character states: 1) head wider than long in both sexes (HL/HW ratio $=0.91-0.94$ in female, $=0.94-0.98$ in male); 2) metepisternum punctate in both sexes; 3 ) female metasomal terga dimly
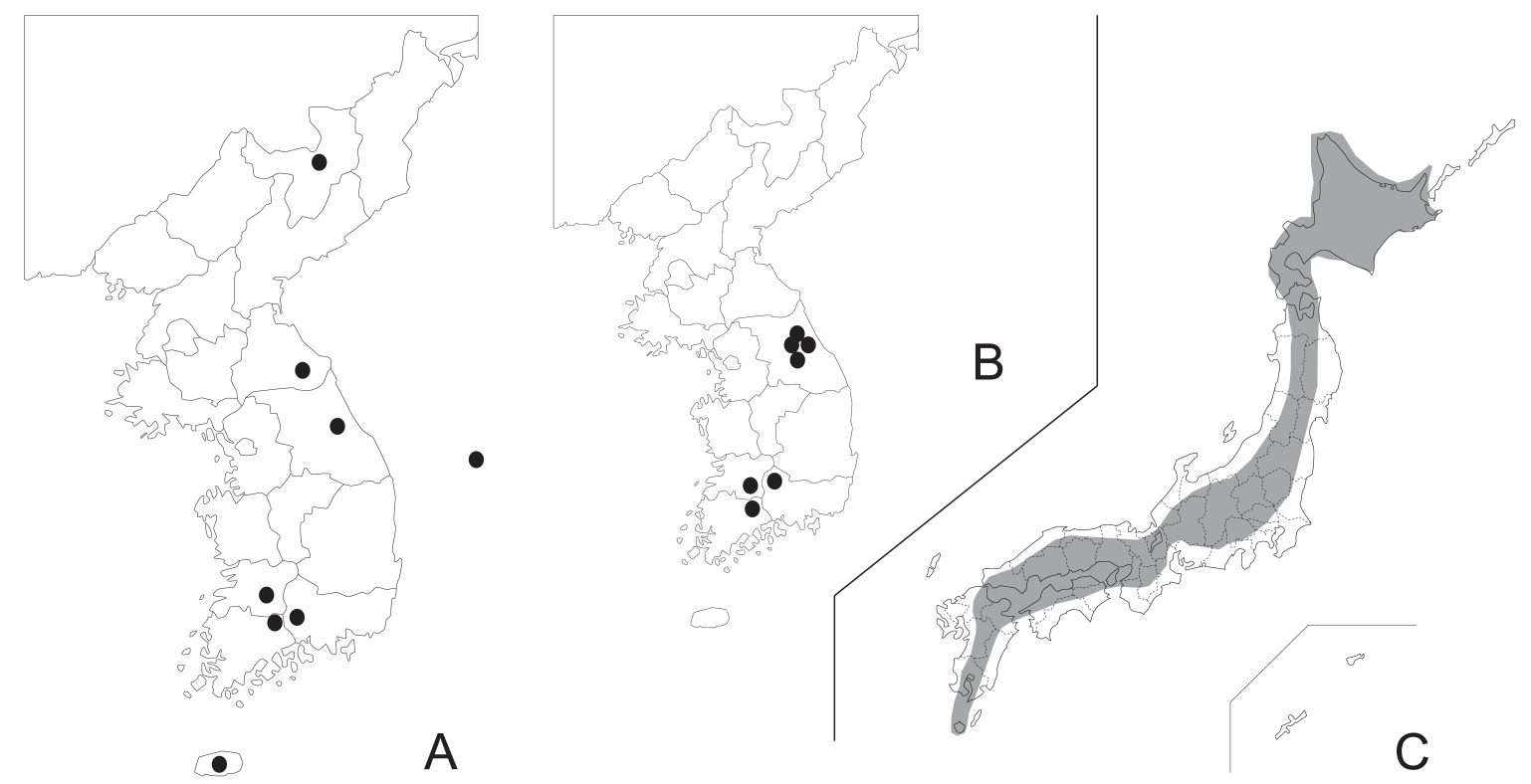

Fig. 22. Distribution maps. A. Lasioglossum (Dialictus) ellipticeps (Blüthgen, 1923) in the Korean Peninsula. B-C. Lasioglossum (Dialictus) miyabei Murao et al., 2006 (B in the Korean Peninsula, C in Japan). 
MURAO R. et al., Dialictus of Japan, the Korean Peninsula, and Taiwan

shiny; 4) male metasomal sterna not modified and 5) and the structure of the male genitalia (Murao et al. 2006; Fig. 9 A-E).

\section{Material examined}

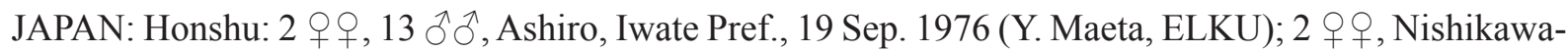
cho, Yamagata Pref., 3 Jun. 2001 (K. Goukon, cGou); 1 ô, Mt. Zao, Yokokawa-rindo, Miyagi Pref., 21 Aug. 2004 (K. Goukon, cGou); 1 ô, Agano, Saitama Pref., 23 Oct. 1971 (T. Nambu, ELKU); 1 , , Sengataki, Karuizawa, Nagano Pref., 27 Sep. 1972 (H. Suda, ELKU); 1 क , Mt. Haku-san, Ishikawa Pref., 30 Jul. 1962 (Y. Haneda, ELKU).

SOUTH KOREA: Gangwon-do: 1 q, Ohsaenk-ri, Yangyang-gun, 17 Apr. 1994 (O. Tadauchi, ELKU); 1 ㅇ, Taewallyong, Myongju-gun, 19 Apr. 1994 (O. Tadauchi, ELKU); 3 우아, Mt. Gariwang-san, Jeongseon-gun, 30 Jul. 2013 (R. Murao, cMur); 3 우, Mt. Gariwang-san, alt. 1100 m, 37²7’15” N $128^{\circ} 1^{\prime} 10^{\prime \prime}$ E, 10 Jun. 2013 (O. Tadauchi, ELKU); 4 우, Mt. Odae-san, alt. 900 m, 3747’0” N 128 32'19 E, 9 Jun. 2013 (O. Tadauchi, ELKU); Mt. Odae-san, 1 +, 10 May 1996 (H.S. Lee, SNU), 1 q, 24 May 2002 (H.S. Lee, QIA); 1 , , Odaesanjang, Mt. Odae-san, Jinbueup, Pyengchang-gun, 24 Apr. 1997 (H.S. Lee, QIA). 14 우, Mt. Seokbyung-san, Imgye-ri, Imgyemyeon, Jeongseon-gun, 22 May 2002 (Y. Lee \& J. Yeo, QIA); Baekdamsa temple, Mt. Seolak-san, Sokchosi, 1 क, 13 May 2010 (J. Jeong, QIA), 4 우, 6 Sep. 2010 (H.S. Lee, QIA); 1 q, Hwacheondong, Imgyemyeon, Jeongseon-gun, 24 Apr. 1997 (J. Son, QIA); 1 +, Hwang-i-ri, Seomyeon, Yangyang-gun, alt. 256 m, 3756’25.8” N 128³1’19.7’ E, 29
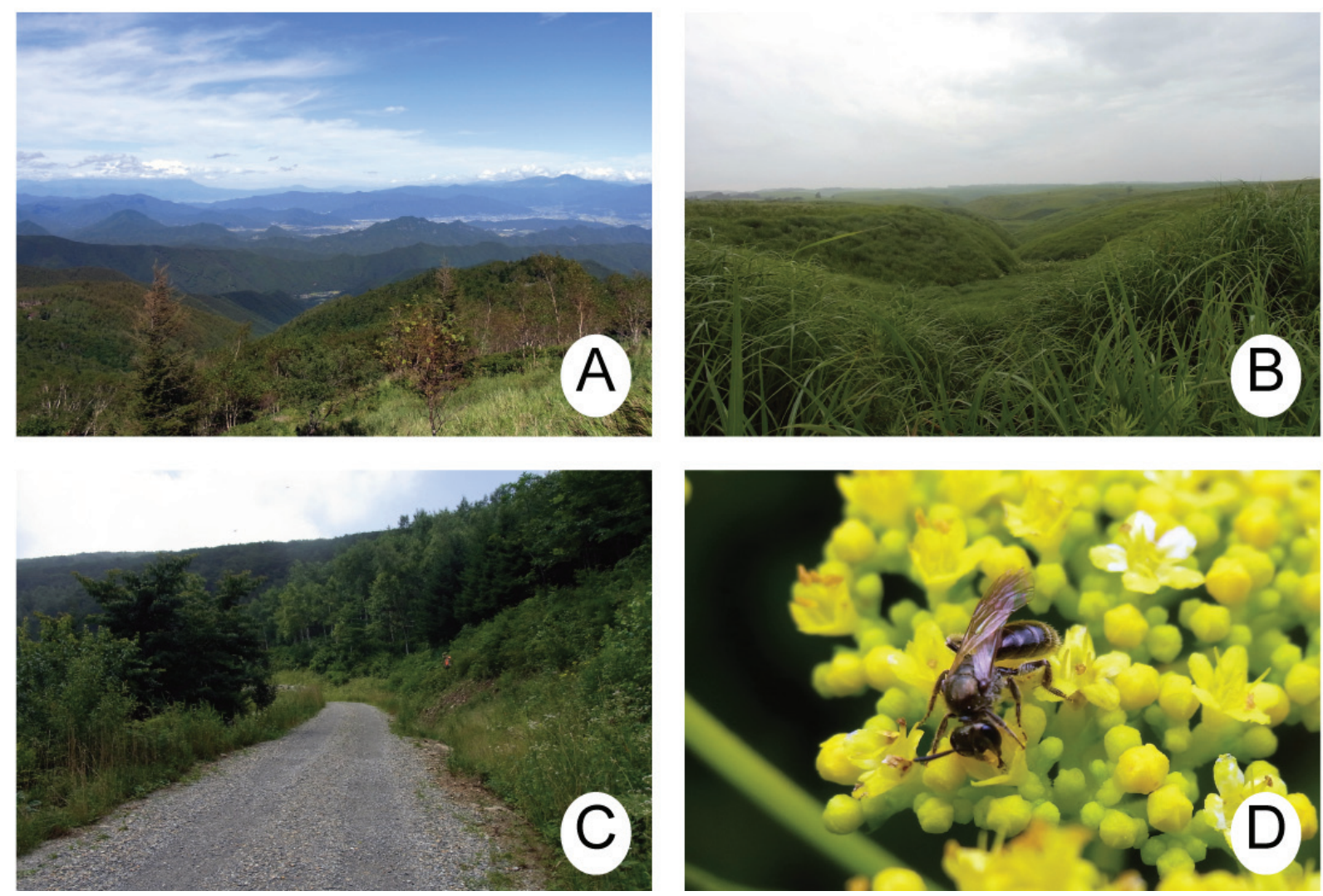

Fig. 23. Habitats in Japan and South Korea. A. Takeshikakami-honiri, Ueda-shi, Nagano Pref., Japan. B. Matoishi wilderness, Aso-shi, Kumamoto Pref., Japan. C. Mt. Gariwangsan, Gangwon-do, South Korea. D. Lasioglossum (Dialictus) miyabei Murao et al., 2006, $q$ on flowers of Patrinia scabiosifolia Fisch. ex Trevir. in South Korea. 

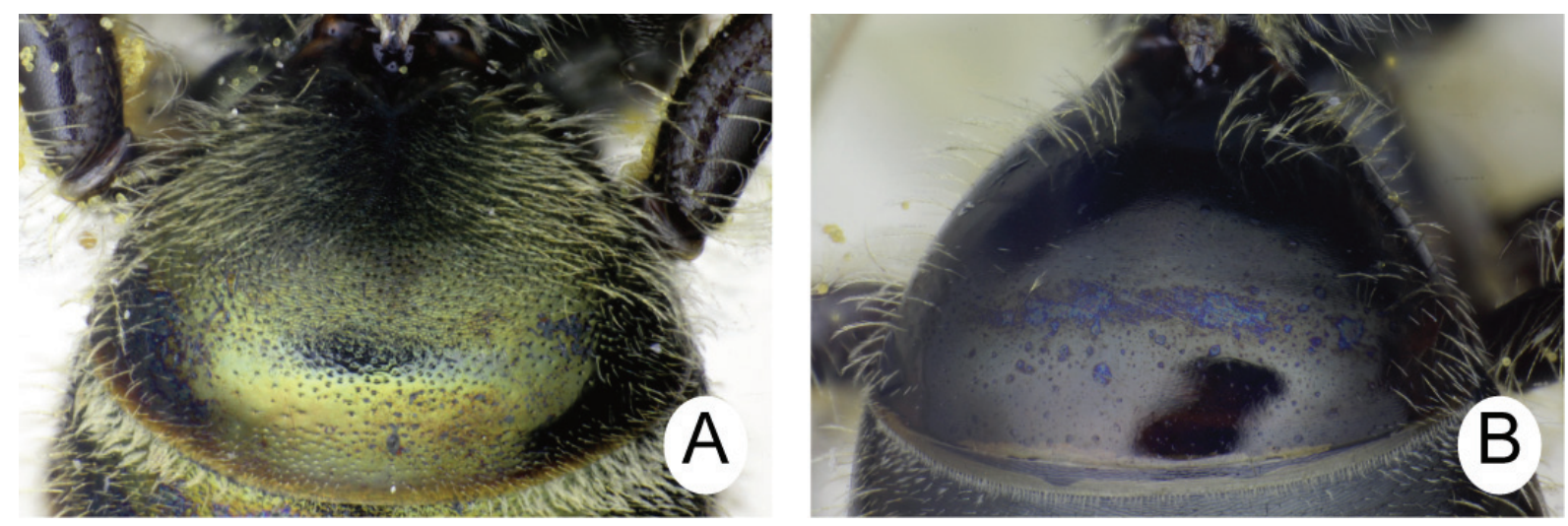

Fig. 24. Photographs for keys: T1 of female. A. Lasioglossum (Dialictus) viridellum (Cockerell, 1931). B. L. (D.) virideglaucum Ebmer \& Sakagami, 1994.
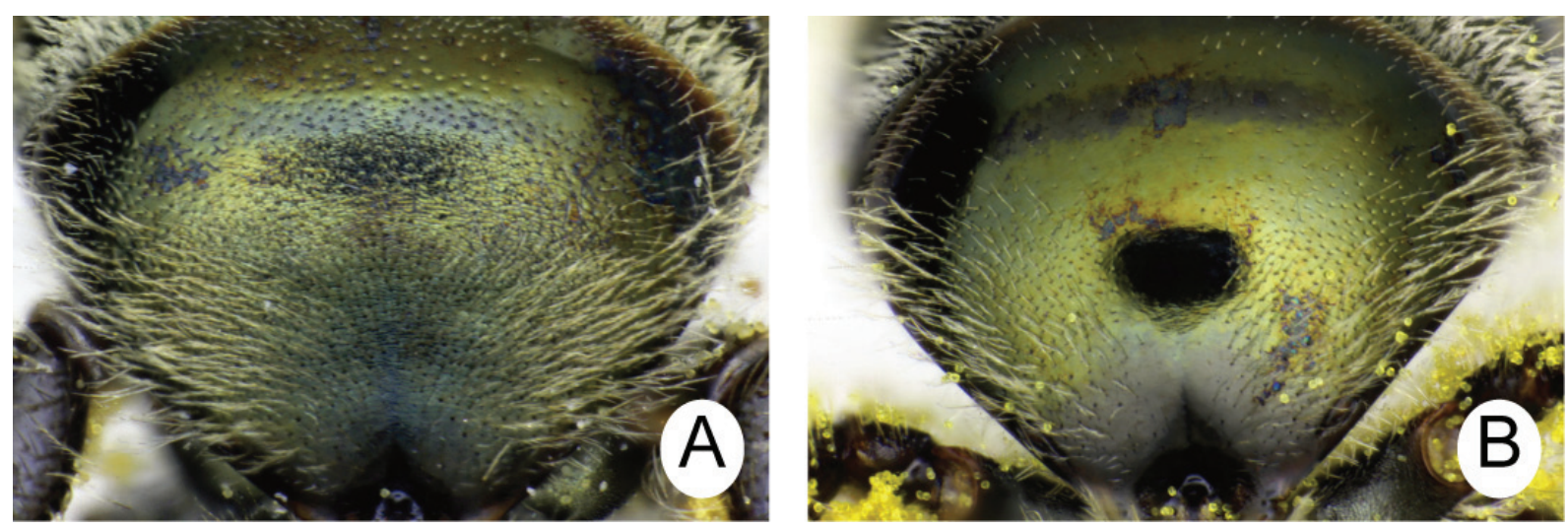

Fig. 25. Photographs for keys: T1 of female. A. Lasioglossum (Dialictus) viridellum (Cockerell, 1931). B. L. (D.) pseudannulipes (Blüthgen, 1925).
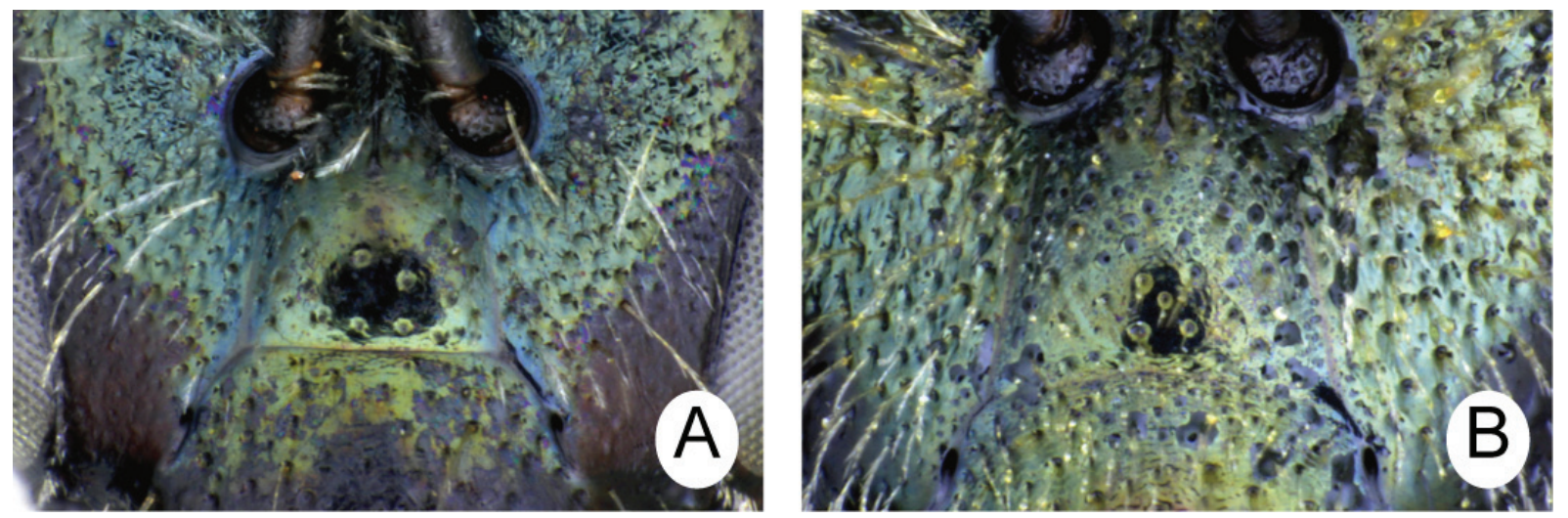

Fig. 26. Photographs for keys: PP on supraclypeal area of female. A. Lasioglossum (Dialictus) meakanense Murao \& Tadauchi, 2009. B. L. (D.) ellipticeps (Blüthgen, 1923). 
MURAO R. et al., Dialictus of Japan, the Korean Peninsula, and Taiwan

Apr. 2007 (H.S. Lee, QIA); Mt. Jeombong-san, 1 甲, 28 Aug. 1999 (H. Kim, SNU), 1 \&, 29 Aug. 1999 (H. Kim, SNU). Jeollabuk-do: 1 , Jeonglyongchy, Sannaemeon, Namweon-gun, 14 May 1991 (T. Saigusa, ELKU); 1 ㅇ, Sanlyong-ri, Sannao-myon, Namweon-gun, 29 Apr. 1992 (O. Tadauchi, ELKU). Gyeongsangnam-do: 1 + , Sam Jeong Li Ma Cheong Meon, Hamyang-gun, 15 May 1991 (T. Saigusa, ELKU). Jeollanam-do: 1 +, Nogodan, Mt. Jiri-san, Gurye-gun, 26 May 1997 (H.S. Lee, QIA).

\section{Distribution}

Russian Far East (Primorsky), the Korean Peninsula (new record) and Japan (Hokkaido, Honshu, Shikoku, Kyushu, northern Ryukyus).

\section{Flight period}

Female: April to October.

Male: July to October.
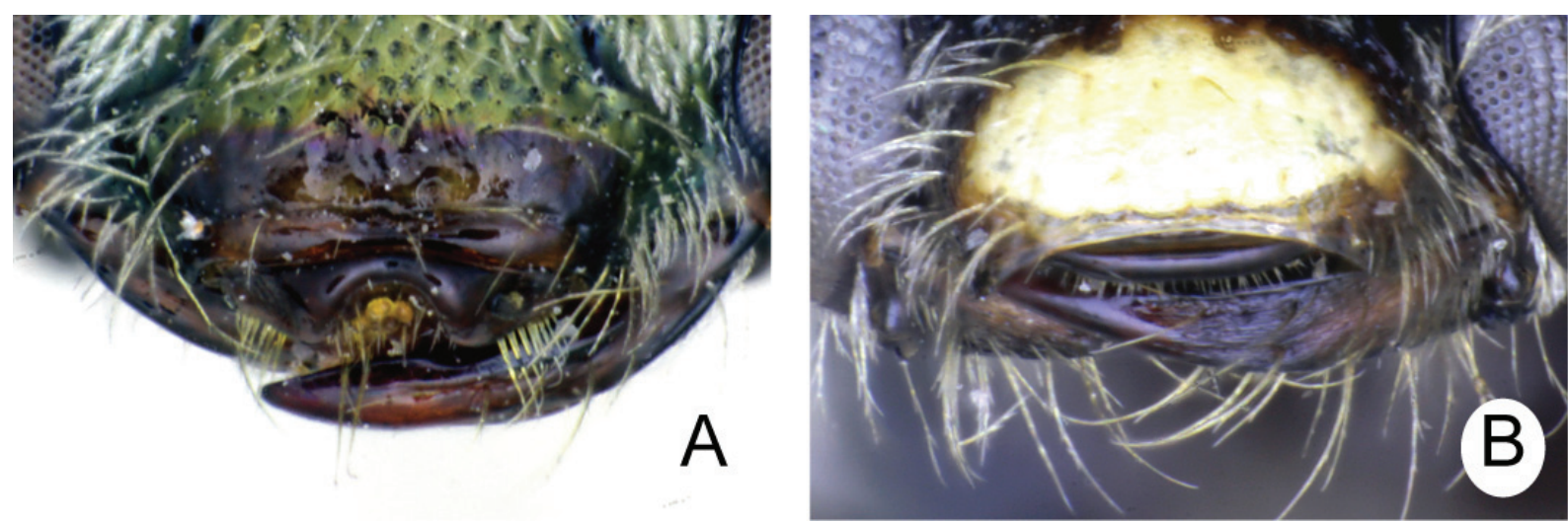

Fig. 27. Photographs for keys: labrum of male. A. Lasioglossum (Dialictus) viridellum (Cockerell, 1931). B. L. (D.) problematicum (Blüthgen, 1923).
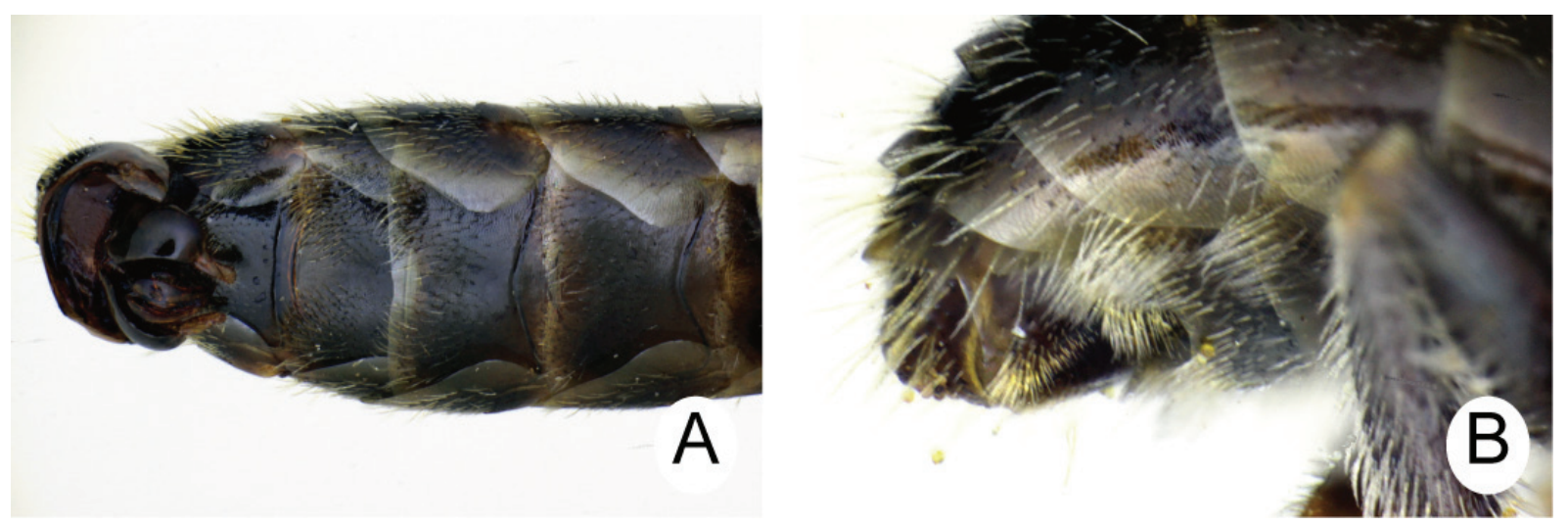

Fig. 28. Photographs for keys: hairs on metasomal sterna of male. A. Lasioglossum (Dialictus) miyabei Murao et al., 2006. B. L. (D.) meakanense Murao \& Tadauchi, 2009. 


\section{Flower records}

The floral records in Japan are reported as 36 species in 13 families by Murao et al. (2006). The specimens from South Korea were collected on the flowers of Aster ageratoides Turcz. (Asteraceae), Potentilla verticillaris Stephan ex Willd. (Rosaceae), Rhododendron mucronulatum Turcz. (Ericaceae), Salix sp. (Salicaceae), Sisymbrium luteum (Maxim.) O.E. Schulz (Brassicaceae), and Syringa sp. (Oleaceae).

\section{Habitat}

This species has been collected in mountain areas in both Japan and South Korea. One of the collecting sites (Mt. Gariwangsan) in South Korea is shown in Fig. 23C.

\section{DNA barcodes}

The COI gene sequences are deposited as DNA barcodes of $L$. (D.) miyabei in the DDBJ under accession number LC027536. This number is also available in GenBank.

\section{Comments}

This species belongs to the atroglaucum group in the dissenting systematic study (Murao et al. 2006; Pesenko 2007a, as subgenus Glauchalictus). It differs, however, considerably with regard to the male character states of the atroglaucum group shown in the present study in having the metasomal sterna without unique hair tufts (Fig. 28A), S4 or S5 not modified (Fig. 28A), and the penis valve of male genitalia without a cleft on top. The systematic status of this species could not be decided in the present study. It will need to be correctly determined using phylogenetic analysis in a future study.

\section{Key to female Lasioglossum (Dialictus) of Japan, the Korean Peninsula and Taiwan:}

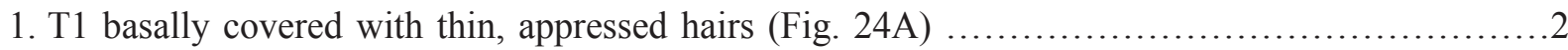

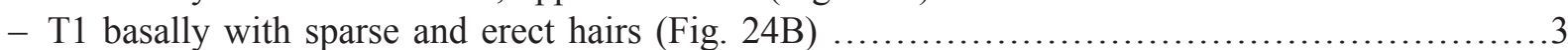

2. T1 usually with strong lineolation on basal to medial area (Fig. 25A)

Lasioglossum (Dialictus) viridellum (Cockerell, 1931)

- T1 without lineolation or with weak lineolation on basal area (Fig. 25B)

L. (D.) pseudannulipes (Blüthgen, 1925)

3. Head wider than long (HL/HW ratio 0.91-0.94, $\mathrm{n}=10)$........ L. (D.) miyabei Murao et al., 2006

- Head nearly as long as wide or longer than wide (HL/HW ratio $0.98-1.12, \mathrm{n}=30) \ldots \ldots \ldots . .4$

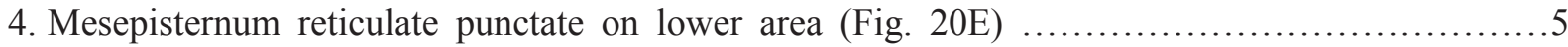

- Mesepisternum sparsely shallow punctate on lower area (e.g., Fig. 6E) .......................6

5. Supraclypeus sparsely punctate as in Fig. 26A (IS $=1-4.7)$

L. (D.) meakanense Murao \& Tadauchi, 2009

- Supraclypeus densely punctate as in Fig. 26B (IS = 1-2) .....L. (D.) ellipticeps (Blüthgen, 1923)

6. Mesoscutum posteriorly nearly smooth

L. (D.) yamanei Murao et al., 2006

- Mesoscutum posteriorly weakly or strongly tessellate

.L. (D.) problematicum (Blüthgen, 1923) and L. (D.) virideglaucum Ebmer \& Sakagami, 1994

\section{Key to male Lasioglossum (Dialictus) of Japan, the Korean Peninsula, and Taiwan:}

1. Clypeus without yellow spot; labrum with basal elevation depressed centrally (Fig. 27A) L. (D.) pseudannulipes (Blüthgen, 1923) and L. (D.) viridellum (Cockerell, 1931)

- Clypeus yellow on lower half; labrum without basal elevation (Fig. 27B) .......................2 
MURAO R. et al., Dialictus of Japan, the Korean Peninsula, and Taiwan

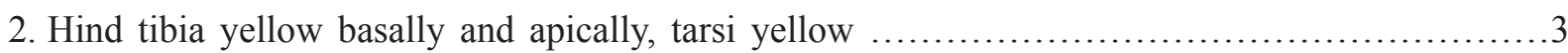

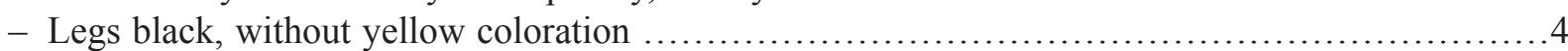

3. Head wider than long $(\mathrm{HL} / \mathrm{HW}$ ratio $0.94-0.98, \mathrm{n}=10)$; metasomal sterna with uniform and sparse hair, without hair tuft (Fig. 28A) ............................ (D.) miyabei Murao et al., 2006

- Head longer than wide (HL/HW ratio 1.07-1.12, n = 5); S5 laterally with moderately long hair tufts (Fig. 28B) ........................................ (D.) meakanense Murao \& Tadauchi, 2009

4. S5 flat on whole surface, without apical depression ......................................... 5

- S5 with shallow or deep apical depression (Fig. 5B, E, H, K, N) ...............................

5. S4-S5 flat, laterally with moderately long hair tufts (Fig. 20F); penis valve of genitalia without cleft on top (Fig. 21C) ...................................... (D.) ellipticeps (Blüthgen, 1923)

- S4-S5 weakly swollen medially; S5 with brush-like hairs along apical margin (Figs 13, 14B, H); penis

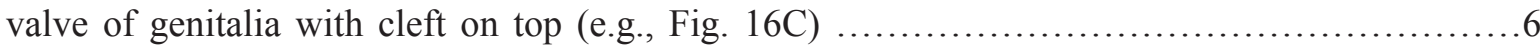

6. Apical margin of S4 straight (Fig. 14A); gonostylus wider than that of L. alishanense (Fig. 16C) L. (D.) problematicum (Blüthgen, 1923)

- Apical margin of S4 incurved (Fig. 14G); gonostylus narrower than that of L. problematicum (Fig. $18 \mathrm{C})$

L. (D.) alishanense Murao sp. nov.

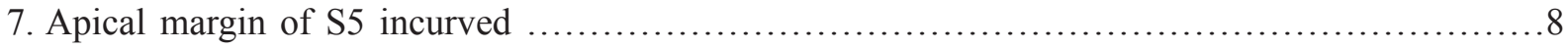

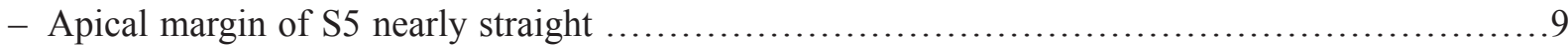

8. Clypeus dull, with strong tessellation; S5 gently incurved (Fig. 5N); gonostylus of genitalia small (Fig.

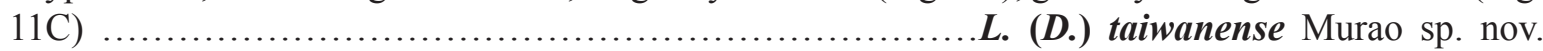

- Clypeus more shiny, with weak tessellation; S5 deeply incurved (Fig. 5H); gonostylus of genitalia large (Murao et al. 2006: fig. 11) .................................... (D.) yamanei Murao et al., 2006

9. S5 with a longitudinal, shallow groove (Fig. 5K) .............. (D.) negoroi Murao \& Tadauchi, 2008

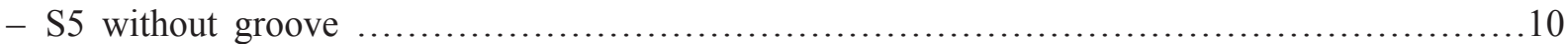

10. Hair pattern of S4 as in Fig. 4B; S6 with a distinct pair of hair tufts (Fig. 4B); gonostylus of genitalia large (Fig. 9C) .........................L. (D.) virideglaucum Ebmer \& Sakagami, 1994

- Hair pattern of S4 as in Fig. 4A; S6 with sparse hairs (Fig. 4A); gonostylus of genitalia small and bud-like (Fig. 7C)

L. (D.) atroglaucum (Strand, 1913)

\section{A checklist of Lasioglossum (Dialictus) in Japan, the Korean Peninsula and Taiwan:}

The leucopus group:

Lasioglossum (Dialictus) pseudannulipes (Blüthgen, 1925): Japan

Lasioglossum (Dialictus) viridellum (Cockerell, 1931): Korean Peninsula

Lasioglossum (Dialictus) meakanense Murao \& Tadauchi, 2009: Japan

\section{The atroglaucum group:}

The atroglaucum subgroup:

Lasioglossum (Dialictus) atroglaucum (Strand, 1913): Taiwan

Lasioglossum (Dialictus) virideglaucum Ebmer \& Sakagami, 1994: Japan, Korean Peninsula

Lasioglossum (Dialictus) yamanei Murao, Ebmer \& Tadauchi, 2006: Japan

Lasioglossum (Dialictus) negoroi Murao \& Tadauchi, 2008: Japan

Lasioglossum (Dialictus) taiwanense Murao sp. nov.: Taiwan 
The problematicum subgroup:

Lasioglossum (Dialictus) problematicum (Blüthgen, 1923): Japan

Lasioglossum (Dialictus) alishanense Murao sp. nov.: Taiwan

\section{The morio group:}

Lasioglossum (Dialictus) ellipticeps (Blüthgen, 1923): Korean Peninsula

\section{Incertae sedis:}

Lasioglossum (Dialictus) miyabei Murao, Ebmer \& Tadauchi, 2006: Japan, Korean Peninsula

\section{Discussion}

Twelve species in total are recognized in the countries studied. All species, except for Lasioglossum (Dialictus) ellipticeps and L. (D.) virideglaucum, are endemic in Far East Asia. The number of species per country is as follows: 7 in Japan, 4 in the Korean Peninsula and 3 in Taiwan. We could not examine enough material of $L$. (Dialictus) from either the Korean Peninsula (particularly, from the sample of North Korea) or Taiwan in the present study to definitively survey the fauna. The number of species in both countries will likely increase, resulting in additional taxonomic studies of the L. (Dialictus) fauna. In the present study, all L. (Dialictus) species from Taiwan are endemic. The other subgenera of Taiwanese Lasioglossum may include many endemic species according to the first author's preliminary examination of Taiwanese Lasioglossum specimens (Murao unpublished). In eastern Asia, Taiwan (as a consequence of the isolation from or land-bridge formation with the continent) and the Ryukyu Islands (Japan, with its many endemic Lasioglossum species, see Murao 2012; Murao \& Tadauchi 2006, 2009b; Murao et al. 2009b, 2010) would be important areas to consider in order to investigate the allopatric speciation of Lasioglossum.

\section{Acknowledgements}

We would like to express our thanks to Dr. Layne Julian Westover (ELKU) for his kindness in brushing up an early draft. Ryuki Murao would especially like to thank Dr. Yulia Astafurova (ZISP), Mr. Fritz Gusenleitner (OLML), Mr. Maximilian Schwarz (Linz, Austria), Mr. Andreas Werner Ebmer (Puchenau, Austria), Dr. Andreas Taeger (SDEI), Mr. Andrew Liston (SDEI) and Dr. Frank Koch (Museum für Naturkunde an der Humboldt Universität zu Berlin, Germany) for their help in my examining their Palaearctic and Oriental Lasioglossum collections. He also thanks Prof. Emeritus Dr. Yasuo Maeta (Shimane, Japan), Mr. Katsuo Goukon (Miyagi, Japan), and Dr. Ryoichi Miyanaga (Shimane University, Japan) for loan of valuable specimens and literature. This research was supported by the JSPS Institutional Program for Young Researcher Overseas Visits (to Murao), the Environment Research and Technology Development Fund (S-9-2(8)) of the Ministry of the Environment, and the Grant-in-Aid for Scientific Research (B) from the Japan Society for the Promotion of Science (No. 24405016) (Head Researcher: Osamu Tadauchi).

\section{References}

Ascher J.S. \& Pickering J. 2015. Discover Life bee species guide and world checklist (Hymenoptera: Apoidea: Anthophila). Available from http://www.discoverlife.org./mp/20q?guide=Apoidea species (accessed 27 Jan. 2015)

Blüthgen P. 1931. Beiträge zur Synonymie der Bienengattung Halictus Latr. VII. (Hym. Apid.). Deutsche Entomologische Zeitschrift 1930: 209-215. 
MURAO R. et al., Dialictus of Japan, the Korean Peninsula, and Taiwan

Danforth B.N. 1999. Phylogeny of the bee genus Lasioglossum (Hymenoptera: Halictidae) based on mitochondrial COI sequence data. Systematic Entomology 24: 377-393. http://dx.doi.org/10.1046/ j.1365-3113.1999.00087.x

Danforth B.N., Conway L. \& Ji S. 2003. Phylogeny of eusocial Lasioglossum reveals multiple losses of eusociality within a primitively eusocial clade of bees (Hymenoptera: Halictidae). Systematic Biology 52: 23-36. http://dx.doi.org/10.1080/10635150390132687

Ebmer A.W. 1978. Die Bienen der Gattungen Halictus Latr., Lasioglossum Curt. und Dufourea Lep. (Hymenoptera, Halictidae) aus Korea. Annales Historico-Naturales Musei Nationalis Hungarici 70: 307-319.

Ebmer A.W. 1982. Zur Bienenfauna der Mongolei: Die Arten der Gattungen Halictus Latr. und Lasioglossum Curt. (Hymenoptera: Halictidae). Ergebnisse der Mongolisch-Deutschen Biologischen Expedition Seit 1962, Nr. 105. Mitteilungen aus dem zoologischen Museum in Berlin 58: 199-227.

Ebmer A.W. 1996. Asiatische Halictidae, 5. Daten zur Aculeaten-Fauna der Ussuri-Region unter Berücksichtigung der angrenzenden Gebiete (Insecta: Hymenoptera: Apoidea: Halictidae: Halictinae). Linzer Biologische Beiträge 28: 261-304.

Ebmer A.W. 1998. Asiatische Halictidae, 7. Neue Lasioglossum-Arten mit einer Übersicht der Lasioglossum s. str.-Arten der nepalischen und yunnanischen Subregion, sowie des nördlichen ZentralChina (Insecta: Hymenoptera: Apoidea: Halictidae: Halictinae). Linzer Biologische Beiträge 30: 365430 .

Ebmer A.W. 2002. Asiatische Halictidae, 10. Neue Halictidae aus China sowie diagnostische Neubeschreibungen der von Fan \& Ebmer 1992 beschriebenen Lasioglossum-Arten (Insecta: Hymenoptera: Apoidea: Halictidae: Halictinae). Linzer Biologische Beiträge 34: 819-934.

Ebmer A.W. 2005. Zur Bienenfauna der Mongolei: Die Arten der Gattungen Halictus Latr. und Lasioglossum Curt. (Insecta: Hymenoptera: Apoidea: Halictidae: Halictinae). Ergänzungen und Korrekturen. Linzer Biologische Beiträge 37: 343-392.

Ebmer A.W. 2006. Daten zur Aculeaten-Fauna der Ussuri-Region unter Berücksichtigung der angrenzenden Gebiete - 2. Arten der Gattungen Halictus, Lasioglossum, Dufourea, Macropis aus dem Lazovski Zapovednik-Naturreservat Laso (Insecta: Hymenoptera: Apoidea: Halictidae, Melittidae). Linzer Biologische Beiträge 38: 541-593.

Ebmer A.W. \& Sakagami S.F. 1990. Lasioglossum (Evylaeus) algirum pseudannulipes (Blüthgen) erstmals in Japan gefunden, mit Notizen über die L. (E.) leucopus-gruppe (Hymenoptera, Halictidae). Japanese Journal of Entomology 58: 835-838.

Ebmer A.W., Maeta Y. \& Sakagami S.F. 1994. Six new halictine bee species from southwest archipelago, Japan (Hymenoptera, Halictidae). Bulletin of the Faculty of Agriculture, Shimane University 28: 23-36.

Folmer O., Black M., Hoeh W., Lutz R. \& Vrijenhoek R. 1994. DNA primers for amplification of mitochondrial cytochrome c oxidase subunit I from diverse metazoan invertebrates. Molecular Marine Biology and Biotechnology 3: 294-299.

Gibbs J. 2010. Revision of the metallic species of Lasioglossum (Dialictus) in Canada (Hymenoptera, Halictidae, Halictini). Zootaxa 2591: 1-382.

Gibbs J. 2011. Revision of the metallic Lasioglossum (Dialictus) of eastern North America (Hymenoptera: Halictidae: Halictini). Zootaxa 3073: 1-216.

Gibbs J., Brady S.G., Kanda K. \& Danforth B.N. 2012. Phylogeny of halictine bees supports origin of eusociality for Halictus and Lasioglossum (Apoidea: Anthophila: Halictidae). Molecular Phylogenetics and Evolution 65: 926-939. http://dx.doi.org/10.1016/j.ympev.2012.08.013 
Gibbs J., Packer L., Dumesh S. \& Danforth B.N. 2013. Revision and reclassification of Lasioglossum (Evylaeus), L. (Hemihalictus) and L. (Sphecodogastra) in eastern North America (Hymenoptera: Apoidea: Halictidae). Zootaxa 3672: 1-117. http://dx.doi.org/10.11646/zootaxa.3672.1.1

Goubara M., Sugimoto Y. \& Sugiura N. 2004. Discovery of 12 species of the genus Lasioglossum from Kyushu Island, Japan (Hymenoptera: Halictidae). Tsunekibachi 3: 51-58. (In Japanese)

Gôkon K. 2006. Flower-visiting insects and their seasonal flunctuation at tideland and sand dune in Gamo Beach, Sendai, northern Japan. Chugoku Kontyu 20: 51-69. (In Japanese)

Hirashima Y. 1957. A tentative catalogue of the genus Halictus Latreille of Japan, and her adjacent territories (Hymenoptera, Halictidae). Science Bulletin of the Faculty of Agriculture, Kyushu University 16: $1-30$.

Ikudome S. 1992. The environment and the wild bee fauna of a natural park in a city, with the result taken at Shiroyama Park in Kagoshima City, Japan, and with the appendix of a revised bee list recorded from the mainland of Kagoshima Prefecture (Hymenoptera, Apoidea). Bulletin of Kagoshima Women's Junior College 27: 99-135. (In Japanese)

Maeta Y., Miyanaga R. \& Kitamura K. 2003. Ecological studies on the wild bee fauna at Mt. Sanbe in Shimane Prefecture, Japan (Hymenoptera, Apoidea). New Entomologist 52: 19-47. (in Japanese)

Michener C.D. 1974. The Social Behavior of the Bees. Belknap Press of Harvard University Press, Cambridge, Massachusetts.

Michener C.D. 2000. The Bees of the World. The Johns Hopkins University Press, Baltimore \& London.

Michener C.D. 2007. The Bees of the World, 2nd ed. The Johns Hopkins University Press, Baltimore \& London.

Morawitz F. 1873. Die Bienen Daghestans. Horae Societatis Entomological Rossicae 10: 129-189.

Murao R. 2012. Lasioglossum (Evylaeus) tadauchii sp. nov. (Hymenoptera, Halictidae) from AmamiOshima, southwestern Japan. Esakia 52: 91-94.

Murao R. 2015. Notes on the distribution of the genus Lasioglossum (Hymenoptera, Halictidae) in eastern Asia. Japanese Journal of Systematic Entomology 21: 1-3.

Murao R \& Tadauchi O. 2006. A new species of the subgenus Evylaeus of the genus Lasioglossum (Hymenoptera, Halictidae) from the Ryukyus, southwestern Japan. Japanese Journal of Systematic Entomology 12: 203-206.

Murao R. \& Tadauchi O. 2007. A revision of the subgenus Evylaeus of the genus Lasioglossum (Hymenoptera, Halictidae) in Japan. Part I. Esakia 47: 169-254.

Murao R. \& Tadauchi O. 2008. A new species of the subgenus Evylaeus of the genus Lasioglossum from northern and central Japan (Hymenoptera: Halictidae). Esakia 48: 37-40.

Murao R. \& Tadauchi O. 2009a. Description of a new species belonging to the subgenus Evylaeus of the genus Lasioglossum (Hymenoptera, Halictidae) from Hokkaido, northern Japan. Biogeography 11: $113-117$.

Murao R. \& Tadauchi O. 2009b. Two new taxa of the leiosoma species-group of the genus Lasioglossum from the Ryûkyû Islands, Japan (Hymenoptera, Halictidae). Japanese Journal of Systematic Entomology 15: 389-399.

Murao R., Ebmer A.W. \& Tadauchi O. 2006. Three new species of the subgenus Evylaeus of the genus Lasioglossum from eastern Asia (Hymenoptera: Halictidae). Esakia 46: 35-51. 
MURAO R. et al., Dialictus of Japan, the Korean Peninsula, and Taiwan

Murao R., Ebmer A.W. \& Tadauchi O. 2009a. Taxonomic position of Lasioglossum (Evylaeus) algirum pseudannulipes (Insecta: Hymenoptera: Halictidae). Species Diversity 14: 165-171.

Murao R., Lee H.S. \& Tadauchi O. 2014. Lasioglossum (Acanthalictus) dybowskii (Hymenoptera, Halictidae) newly recorded from South Korea, with a checklist of the genus Lasioglossum in Korean Peninsula. Journal of Hymenoptera Research 38: 141-153. http://dx.doi.org/10.3897/JHR.38.7572

Murao R., Tadauchi O. \& Yamauchi T. 2009b. Taxonomic revision of the subgenus Ctenonomia of the genus Lasioglossum (Hymenoptera, Halictidae) in Japan. Esakia 49: 75-94.

Murao R., Tadauchi O., Goubara M. \& Maeta Y. 2010. Taxonomy of the carinaless group of Lasioglossum (Evylaeus) (Hymenoptera, Halictidae) from the Ryukyu Islands, Japan, with description of seven new species. Zootaxa 2669: 1-33.

Negoro H. 2012. Flower-visiting habits of wild bees in Toyama Prefecture, Hokuriku, Japan. Bulletin of the Toyama Science Museum 36: 55-128. (In Japanese)

Pauly A., Gibbs J. \& Kuhlmann M. 2012. Capalictus, a new subgenus of Lasioglossum Curtis, 1833 from South Africa, with description of three new species (Hymenoptera, Apoidea, Halictidae). European Journal of Taxonomy 28: 1-28. http://dx.doi.org/10.5852/ejt.2012.28

Pauly A., Walker K., Munzinger J. \& Donovan B. 2013. Endémisme insulaire et cleptoparasitisme chez les Lasioglossum Curtis 1833 (Hymenoptera: Apoidea: Halictidae) de Nouvelle-Calédonie. Annales de la Société entomologique de France (N. S.) 49: 127-153. http://dx.doi.org/10.1080/00379271.2013.815036

Pesenko Y.A. 2006. Contributions to the halictid fauna of the Eastern Palaearctic Region: genus Lasioglossum Curtis (Hymenoptera: Halictidae, Halictinae). Zoosystematica Rossica 15: 133-166.

Pesenko Y.A. 2007a. Subgeneric classification of the Palaearctic bees of the genus Evylaeus Robertson (Hymenoptera: Halictidae). Zootaxa 1500: 1-54.

Pesenko Y.A. 2007b. A taxonomic study of the bee genus Evylaeus Robertson of Eastern Siberia and the Far East of Russia (Hymenoptera: Halictidae). Zoosystematica Rossica 16: 79-123.

Sakagami S.F. \& Fukuda H. 1973. Wild bee survey at the campus of Hokkaido University. Journal of the Faculty of Science, Hokkaido University, Series VI, Zoology 19: 190-250.

Sakagami S.F. \& Kuribayashi S. 1979. On the semisocial halictine bees. Anima 79: 54-60. (In Japanese)

Sakagami S.F. \& Michener C.D. 1962. The Nest Architecture of the Sweat Bees (Halictinae), a Comparative Study. University of Kansas Press, Lawrence.

Sakagami S.F., Hoshikawa K. \& Fukuda H. 1984. Overwintering ecology of two social halictine bees, Lasioglossum duplex and L. problematicum. Researches on Population Ecology 26: 363-378.

Sakagami S.F. Laroca S. \& Moure J.S. 1967. Wild bee biocoenotics in São José dos Pinhais (PR), South Brazil. Preliminary report. Journal of the Faculty of Science, Hokkaido University, Series VI, Zoology 16: $253-291$.

Strand E. 1913. H. Sauter's Formosa-Ausbeute. Apidae II (Die Halictus-Arten von Formosa). Archiv für Naturgeschichte 79A: 147-171.

Tamura K.,Peterson D., Peterson N., Stecher G., Nei M. \& Kumar S. 2011. MEGA5: Molecularevolutionary genetics analysis using maximum likelihood, evolutionary distance, and maximum parsimony methods. Molecular Biology and Evolution 28: 2731-2739. http://dx.doi.org/10.1093/molbev/msr121

Usui M., Nishijima Y., Fukuda H. \& Sakagami S.F. 1976. A wild bee survey in Obihiro Eastern Hokkaido. Research Bulletin of Obihiro University, Series I 10: 225-251. 
Yamauchi K., Murakumo Y., Ogura M. \& Sakagami S.F. 1974. Biofaunistic survey of wild bees in Minami (Gifu Prefecture), Central Japan. Science Report of the Faculty of Education, Gifu University (Natural Science) 5: 220-232. (In Japanese)

Yanega D. 1997. Demography and sociality in halictine bees (Hymenoptera: Halictidae). In: Choe J.C. \& Crespi B.J. (eds) The Evolution of Social Behavior in Insects and Arachnids: 293-315. Cambridge University Press, Cambridge, U.K.

Yonekura K. \& Kajita T. 2003-. BG Plants Japanese-scientific names index (Ylist). Available from http://ylist.info/index.html [accessed 11 Aug. 2015].

Manuscript received: 11 March 2015

Manuscript accepted: 3 June 2015

Published on: 14 September 2015

Topic editor: Koen Martens

Desk editor: Kristiaan Hoedemakers

Printed versions of all papers are also deposited in the libraries of the institutes that are members of the EJT consortium: Muséum National d'Histoire Naturelle, Paris, France; Botanic Garden Meise, Belgium; Royal Museum for Central Africa, Tervuren, Belgium; Natural History Museum, London, United Kingdom; Royal Belgian Institute of Natural Sciences, Brussels, Belgium; Natural History Museum of Denmark, Copenhagen, Denmark. 